Gerardo Kuntschik

Estimativa de biomassa vegetal lenhosa em cerrado por meio de sensoriamento remoto óptico e de radar

\author{
EXEMPLAR CORRIGIDO
}

São Paulo

2004 


\author{
Gerardo Kuntschik
}

\title{
Estimativa de biomassa vegetal lenhosa em cerrado por meio de sensoriamento remoto óptico e de radar
}

Tese apresentada ao Instituto de Biociências da Universidade de São Paulo, para a obtenção de Título de Doutor em Ciências, na Área de Ecologia.

Orientadora: Profa. Dra. Marisa Dantas Bitencourt

São Paulo

2004 


\section{Kuntschik, Gerardo}

Estimativa de biomassa vegetal lenhosa em cerrado por meio de sensoriamento remoto óptico e de radar

\section{4 páginas}

Tese (Doutorado) - Instituto de Biociências da Universidade de São Paulo.

Departamento de Ecologia.

1. Cerrado 2. Estimativa de biomassa 3. Sensoriamento Remoto. Universidade de São Paulo. Instituto de Biociências. Departamento de Ecologia.

\section{Comissão Julgadora:}

Profa. Dra. Tatiana Mora Kuplich

Prof. Dr. Edson E. Sano
Prof. Dr. João Roberto dos Santos

Prof. Dr. Wellington B. C. Delitti

Profa. Dra. Marisa Dantas Bitencourt

Orientadora 
Aos meus pais

Juanita e Gerardo 


\section{Agradecimentos}

À Dra. Marisa Dantas Bitencourt, minha orientadora, quem disponibilizou todos os meios para possibilitar este trabalho.

Ao Dr. Waldir Mantovani pela ajuda na parte de levantamento de campo e fitossociologia.

Aos pesquisadores do Instituto Nacional de Pesquisas Espaciais: Dr. Flávio Ponzoni, Prof. Marinaldo Gleriani, Dr. Alexandre Cândido Xavier, Dr. Getulio T. Batista, À Daniela Petenon.

Aos amigos da USP.

Ao Marcelo Matsumoto.

Ao Paulo César Fernandes e aos alunos Marina Amado de Almeida e Carlos L. de Barros Tomba.

Aos amigos Max e Dânae

A Ligia, Pablo, Gabriela e Gustavo, minha família no Brasil.

Ao Dr. Jurandir Zullo, do CIAGRI - UNICAMP.

À Coordenação7 de Aperfeiçoamento de Pessoal de Nível Superior pela bolsa concedida.

À Fundação de Amparo à Pesquisa do Estado de São Paulo pelo financiamento através do Projeto "The Conservation Feasibility of Cerrado Remnants in São Paulo State" (FAPESP processo $n^{\circ}$ 98-05251$0)$. 


\section{Índice}

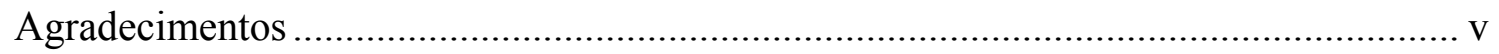

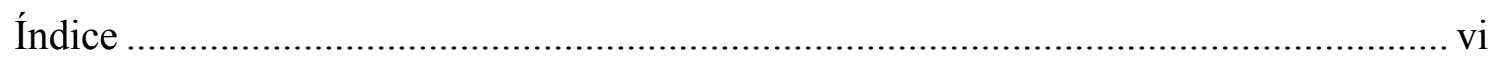

Lista de Abreviaturas, siglas e acrônimos ................................................................ viii

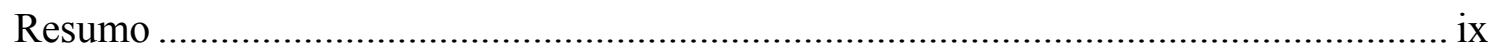

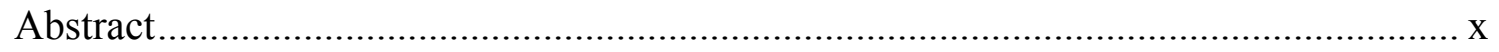

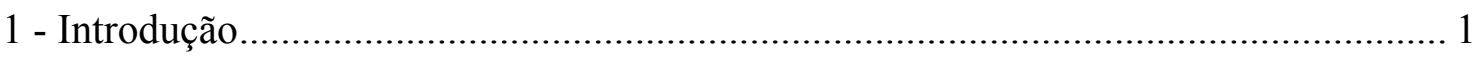

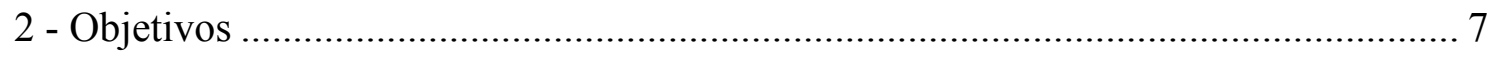

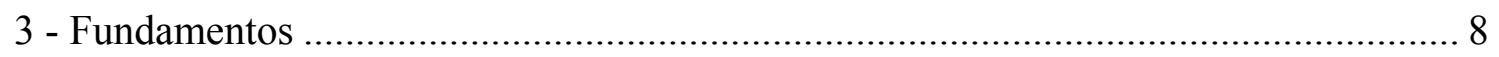

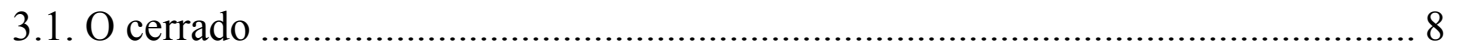

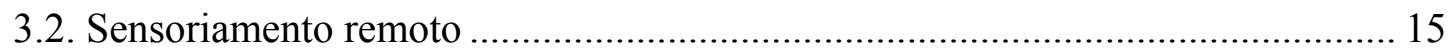

3.2.1. Sensoriamento remoto por sistemas ópticos........................................... 18

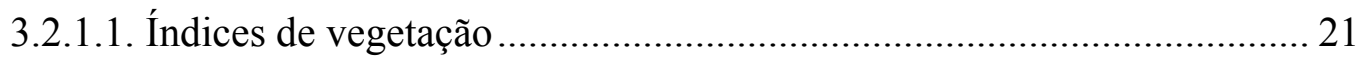

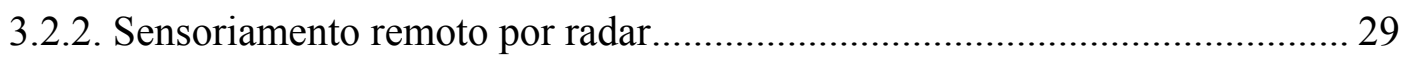

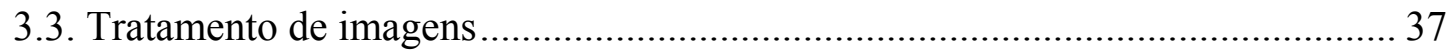

3.3.1. Tratamento de imagens ópticas: correção atmosférica............................... 37

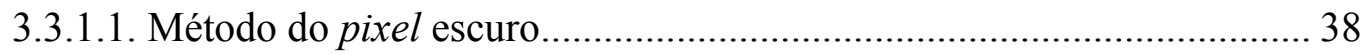

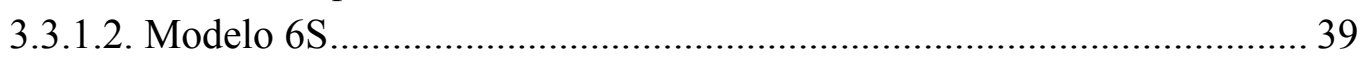

3.3.2. Tratamento de imagens de radar......................................................... 41

3.4. Métodos não destrutivos de avaliação de biomassa vegetal............................... 42

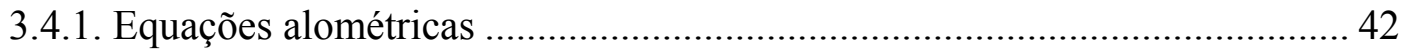

3.4.2. Métodos de amostragem da vegetação florestal .......................................... 44

3.4.3. Estimativa de índice de área foliar ......................................................... 48

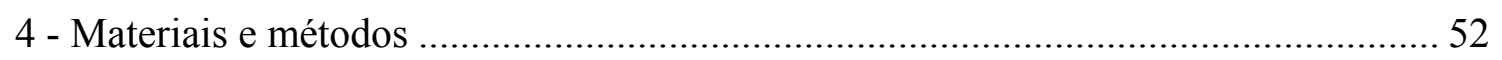

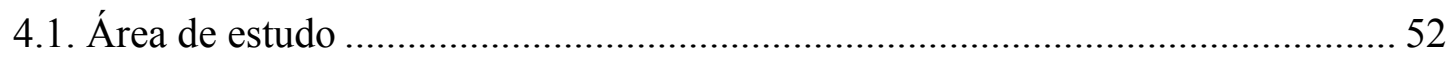

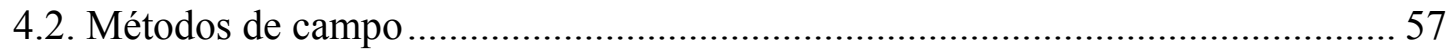

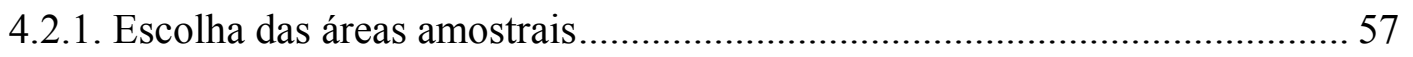


4.2.2. Estimativa do IAF 70

4.2.3. Estimativa da biomassa lenhosa aérea em áreas de fisionomias florestais... 72

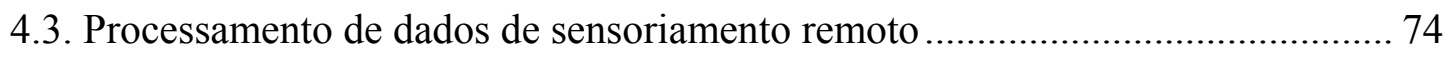

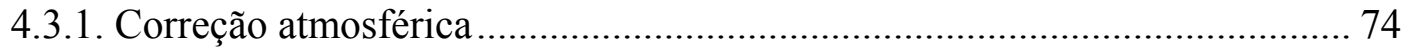

4.3.2. Georreferenciamento das imagens ópticas .............................................. 75

4.3.3. Georreferenciamento da imagem JERS-1 ….......................................... 75

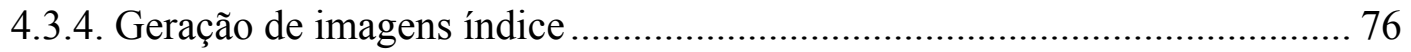

4.4. Metodologia para integração e análise de dados de campo e sensoriamento

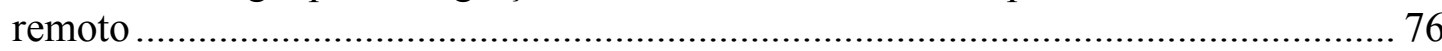

4.4.1. Relação entre Índice de Área Foliar e Índices de Vegetação em áreas abertas 77

4.4.2. Caracterização da relação entre biomassa florestal aérea e imagens de radar

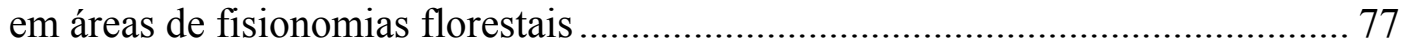

4.4.2.1. Processamento digital da imagem de radar ........................................ 78

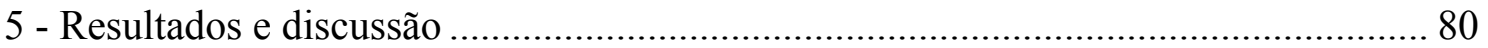

5.1. Relação entre Índice de Área Foliar e Índices de Vegetação em áreas abertas... 80

5.2. Caracterização da relação entre biomassa florestal aérea e imagens de radar em

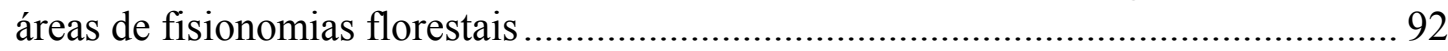

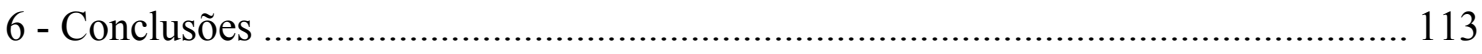

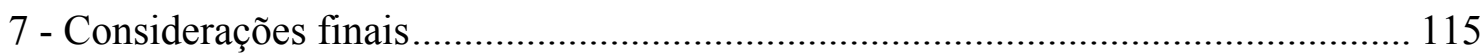

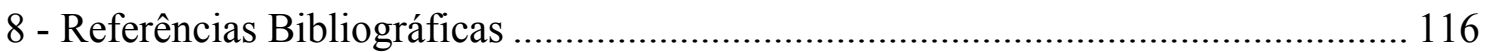

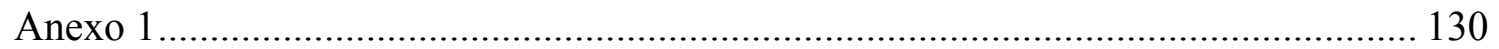

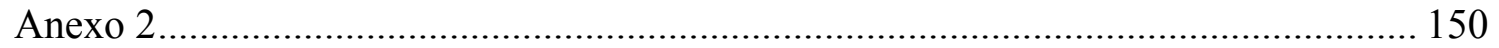




\section{Lista de Abreviaturas, siglas e acrônimos}

AAP: Área à Altura do Peito

AB: Área Basal.

CTC: Capacidade de troca de cátions

dB: Decibéis

CAP: Circunferência à Altura do Peito $(1,3 \mathrm{~m})$

CF: Calibration factor (fator de calibração)

DAP: Diâmetro à Altura do Peito $(1,3 \mathrm{~m})$

DB: Diâmetro na Base

DN: Digital number (número digital do pixel)

ETM+: Enhanced Thematic Mapper

EVI: Enhanced Vegetation Index. Equivale ao EVI em português

GHz: Giga Hertz

h: altura

Hz: Hertz

IAF: Índice de Área Foliar

IBGE: Instituto Brasileiro de Geografia e Estatística

IET: International Emissions Trading

INPE: Instituto Nacional de Pesquisas Espaciais

IVDN: Normalized Difference Vegetation Index. Equivale ao NDVI em Português

IVR: Índice de Vegetação Realçado

JERS-1: Japanese Earth Resources Satellite

MODIS: Moderate Resolution Imaging Spectroradiometer

NASA: National Aeronautics and Space Administration (Agência Espacial Americana)

NDVI: Índice de Vegetação Diferença Normalizada

PB: Perímetro na Base do Caule

PVA: Solos Podzólicos Vermelho Amarelos RAR: Real aperture radar (radar de

abertura real)

SAR: Synthetic aperture radar (radar de abertura sintética)

SAVI: Soil Adjusted Vegetation Index (Índice de Vegetação ajustado ao Solo)

SIR-C/X: Spaceborne Imaging Radar c/x (Radar a bordo de nave espacial que opera nas bandas c e $\mathrm{X}$ )

SMA: Secretaría do Meio Ambiente do Estado de São Paulo TM: Thematic Mapper

WRS: World Reference System

6S: Second simulation of the satellite signal in the solar spectrum 


\section{Resumo}

O objetivo do presente estudo é avaliar a possibilidade de utilizar o sensoriamento remoto óptico e o sensoriamento remoto por microondas de modo complementar na estimativa de biomassa vegetal aérea em áreas de cerrado no estado de São Paulo. A metodologia proposta visa quantificar biomassa de forma não destrutiva, rápida e a baixo custo. $\mathrm{O}$ trabalho foi desenvolvido em uma área com remanescentes de cerrado ao Sudoeste do estado de São Paulo. Utilizaram-se imagens Índice de Vegetação Diferença Normalizada - IVDN e Índice de Vegetação Realçado - IVR, produzidas a partir de imagens do sensor Enhanced Thematic Mapper - ETM+ a bordo do satélite Landsat7 para estimar Índice de Área Foliar - IAF em áreas de vegetação aberta de cerrado. Também foi utilizada uma imagem de radar, banda L, do satélite Japanese Earth Resources Satellite - JERS-1. Os resultados de estimativa de IAF através de imagens IVDN e IVR não foram satisfatórios, devido à inadequabilidade da técnica de amostragem no campo para as áreas abertas. A estimativa de biomassa lenhosa aérea por imagens de radar forneceu resultados significativos. Estes resultados permitiram determinar uma equação que descreve o comportamento do sinal de radar em função da quantidade de biomassa lenhosa aérea em fisionomias florestais do bioma cerrado. Esta equação pode ser útil na estimativa de biomassa em outras áreas de cerrado. 


\section{Abstract}

The objective of this study is to evaluate the feasibility of using radar and optical remote sensing in a complementary way to estimate above ground vegetal biomass. Two non destructive, fast and low cost methodologies for biomass quantification of different physiognomies of cerrado were proposed. The work was carried out in an area with remnants of cerrado in the Southwest of São Paulo State. Normalized Difference Vegetation Index - NDVI and Enhanced Vegetation Index - EVI images from Enhanced Thematic Mapper ETM+ sensor on board of Landsat7 satellite were used to estimate Leaf Area Index - LAI in open cerrado areas. A L band radar image was also used for dense woody biomass estimation. The sampling technique used in the field shown to be unsuitable for the open physiognomies of cerrado. As a consequence, results of LAI estimation through IVDN and IVR images were not satisfactory. Aboveground woody biomass estimation through radar image yield significant results. Based on those data, as equation that describes the behavior of the of radar signal as a function of the amount of aboveground woody biomass in cerradão was found. This equation can be useful to estimate aboveground woody biomass in other cerrado areas. 


\section{1 - Introdução}

Denomina-se biomassa à quantidade total de material biológico, a massa combinada de todos os animais e plantas que habitam uma área específica ou de uma determinada população (ART, 1998). O conhecimento da quantidade e distribuição da biomassa vegetal é importante em várias áreas do conhecimento, tanto nas ciências agronômicas quanto na ecologia. A exploração eficiente das florestas, tanto implantadas quanto nativas, no nível comercial, requer este conhecimento, especialmente quando se deseja saber a quantidade de madeira disponível. Todo plano de manejo eficiente prevê a quantificação desta variável biofísica, seja para fins acadêmicos, seja para fins comerciais. No plano acadêmico, esse tipo de dados é particularmente importante no estudo dos fluxos e balanço de carbono (DÍAZ-BALTEIRO; JOHNSON et al. 2001; ROMERO, 2003). Tanto o fluxo quanto o balanço de carbono têm merecido muita atenção nos últimos anos devido à importância que alguns gases, que contêm esse elemento, desempenham nos processos de mudanças ambientais, principalmente no aquecimento global da atmosfera. O conhecimento da quantidade de carbono armazenado nos diferentes reservatórios é fundamental para o estudo e a compreensão de outros processos envolvidos nos fluxos de energia e da água (FEARNSIDE, 1996; TIAN et al. 2000).

Juntamente com os oceanos, a atmosfera é o grande reservatório de carbono do planeta (OHSUMI, 2002; SCHULZE et al. 2000). Esse elemento pode ser absorvido pela vegetação na forma de $\mathrm{CO}_{2}$ pelo processo da fotossíntese e armazenado na forma de substâncias orgânicas. O carbono, já na forma de moléculas complexas, pode ser subseqüentemente repassado a indivíduos integrantes de outros níveis tróficos. 
Posteriormente, pode ser liberado novamente à atmosfera pela respiração ou outros meios de oxidação da matéria orgânica, como a decomposição anaeróbia ou a combustão. O carbono armazenado na vegetação é a forma mais rapidamente intercambiável deste elemento com o meio. O constante incremento de gases carbônicos na atmosfera, particularmente o $\mathrm{CO}_{2}$ e o $\mathrm{CO}$, tem originado amplas discussões sobre as alternativas que poderiam diminuir o balanço de liberação destes gases visando minimizar o impacto no meio ambiente. O papel que esses gases desempenham no efeito estufa tem sido um motivo que incentivou o estudo dos fluxos do carbono na biosfera (HOUGHTON et al. 2001; SCHROEDER; WINJUM, 1995).

Duas propostas têm chamado a atenção: a diminuição da emissão destes gases, fundamentalmente pela substituição do uso de combustíveis fósseis por alternativas renováveis e o seqüestro e armazenamento de carbono atmosférico. Essa última opção parece ser uma alternativa viável, através da retirada do $\mathrm{CO}_{2}$ da atmosfera pela vegetação, recebendo um amplo apoio internacional no Protocolo de Kyoto. Os documentos desse acordo propõem uma série de mecanismos de quantificação de emissões e metas de carbono liberado que deveriam ser cumpridas pelos países signatários. Além disso, propõem a criação de um mercado no qual se comercializariam quotas ou direitos de emissão. Sendo assim, países que liberam menor quantidade de carbono do que é permitido poderiam vender esse superávit em um mercado internacional, denominado International Emissions Trading (IET). Outro mecanismo contemplado no Protocolo de Kyoto é o Clean Development Mechanism, pelo qual os países desenvolvidos poderiam implementar projetos de retirada de carbono atmosférico em outros países e assim compensarem suas próprias emissões. Em decorrência deste acordo, a quantificação de biomassa vegetal tem se tornado cada vez mais importante, 
pois sua implementação exige realizar determinações da quantidade de carbono armazenado pela vegetação (FOODY et al. 1996; FOODY et al. 2001; MYNENI, et al. 2001; DE KONING et al. 2002; JANSSENS et al. 2003; SANCHEZ-AZOFEIFA et al. 2003, THE ROYAL SOCIETY, 2001). Essas determinações são realizadas através de medições diretas no campo e posteriormente são feitas extrapolações com sistemas de informação geográfica e sensoriamento remoto. O conteúdo de carbono armazenado pela vegetação é estimado a partir da aplicação de coeficientes apropriados a dados de biomassa (THE ROYAL SOCIETY, 2001).

A distribuição da biomassa vegetal nos indivíduos tem uma porção aérea e uma subterrânea. A proporção em que se distribui essa biomassa vegetal não é constante para todos os indivíduos, inclusive dentro da mesma espécie, e está sujeita a fatores diversos. Entre esses fatores, podemos mencionar as características genéticas das espécies, a idade dos indivíduos e as condições do ambiente (CASTRO; KAUFFMAN, 1998; DELITTI et al. 2001).

O cálculo da quantidade de biomassa vegetal total inclui a quantificação da parte aérea e da subterrânea. Essa última é difícil de ser determinada e poucos trabalhos têm sido desenvolvidos se comparados com os estudos da parte aérea (ABDALA et al. 1998; DELITTI et al. 2001).

No que tange à biomassa vegetal aérea, destacam-se duas porções: as folhas e os troncos e galhos. Os métodos utilizados para quantificar estas duas porções são quase sempre distintos.

Destacam-se também, dois grandes grupos de métodos para quantificação de biomassa vegetal, que são diferenciados de acordo com a preservação ou não do material em estudo: São os métodos destrutivos e os métodos não destrutivos. 
Os métodos destrutivos têm a vantagem de permitir a quantificação direta dessa biomassa. Por outro lado, esse tipo de determinação tem como desvantagem o fato de ser mais trabalhosa, demorada e cara. É importante salientar que, em alguns casos, estes métodos não são adequados aos requisitos impostos pela natureza do trabalho. Quando isso ocorre, deve-se recorrer a métodos alternativos. Freqüentemente, é necessário realizar um acompanhamento do crescimento de um ou mais indivíduos ao longo do tempo. Neste caso, a utilização de métodos destrutivos deve ser descartada, já que a natureza desse tipo de método impossibilita a medição do mesmo indivíduo em diferentes épocas. Outra situação usualmente defrontada é a impossibilidade legal do uso de métodos destrutivos. Os marcos legais que regulam as atividades de pesquisa dentro das unidades de conservação muitas vezes limitam grandemente ou até impedem o corte e destruição de indivíduos da flora local, impossibilitando assim a utilização desses métodos. Em outras ocasiões, dependendo da finalidade do trabalho, a determinação de biomassa vegetal precisa ser feita dentro de propriedades particulares. Mesmo nesses casos, é comum não se poder utilizar métodos destrutivos, seja por exigência dos donos da propriedade, seja pela proibição por parte da autoridade ambiental quanto ao corte das árvores da flora nativa. Essa última situação ocorre tipicamente quando a determinação de biomassa deve ser realizada em áreas identificadas como reserva legal ou de preservação permanente.

A medição da variável de interesse, normalmente a massa das árvores, requer o corte e pesagem das árvores (MATTEUCHI; COLMA, 1982), podendo ser a totalidade dos indivíduos em questão, ou somente os integrantes de uma amostra representativa. 
Dentro do grupo dos métodos não destrutivos de quantificação de biomassa vegetal encontram-se a utilização de equações alométricas e os métodos que utilizam produtos de sensoriamento remoto.

As equações alométricas utilizam a modelagem de variáveis biofísicas, tipicamente altura e diâmetro, para estimar a quantidade de biomassa ou o volume das árvores. O procedimento para determinar as equações alométricas consiste em medir variáveis da vegetação e procurar uma função que caracterize a relação existente entre elas. Em geral, são medidas a altura, o DAP e a biomassa de um conjunto de árvores. Posteriormente, procura-se a relação existente entre os valores amostrados. A determinação da biomassa é feita por um método destrutivo. O processo de elaboração de equações alométricas envolve aplicação de um método destrutivo da biomassa, porém, a aplicação destas equações é um método não destrutivo de estimativa de biomassa.

As imagens índice de vegetação, derivadas basicamente de imagens do vermelho e do infravermelho próximo, são freqüentemente empregadas na estimativa não destrutiva da biomassa fotossinteticamente ativa (folhas) de várias formações vegetais (BOELMAN et al. 2003; FOODY et al. 1996; FOODY et al. 2001). No entanto, a extrapolação das relações entre imagens índice de vegetação e valores de biomassa determinados no campo para uma região determinada apresenta dificuldades que ainda não foram totalmente resolvidas (FOODY et al, 2003).

O sensoriamento remoto por radar, que trabalha na faixa das microondas, cada vez mais tem sido utilizado para estimar valores de biomassa vegetal das partes não fotossinteticamente ativas (tronco e galhos). Estes sistemas apresentam algumas vantagens quando comparados com os sistemas ópticos, pois são pouco sensíveis aos 
efeitos atmosféricos, os quais representam um problema sério em imagens ópticas de áreas freqüentemente cobertas por nuvens. Outra vantagem importante é que esses sistemas permitem estimar a quantidade de biomassa vegetal total de ecossistemas mais densos, pois nesses casos a radiação interage não somente com as folhas, mas também com os troncos e galhos, dependendo do comprimento de onda. Segundo a literatura (BITENCOURT PEREIRA, 1986; HUETE et al. 1997; HUETE et al. 1999; JACKSON; HUETE, 1991; JUSTICE, 1986; TUCKER et al. 1985), as imagens índice de vegetação apresentam desempenho adequado na estimativa de IAF em áreas abertas. As imagens de radar da banda L, por sua vez, têm se mostrado úteis na estimativa de biomassa em áreas lenhosa, em fisionomias florestais (AUSTIN et al. 2002; KASISCHKE et al. 1997; LUCKMAN et al. 1997; LUCKMAN et al. 1998; RANSON et al. 1997; SANTOS et al. 2000; SANTOS et al. 2002; SUN et al. 2002).

A hipótese deste trabalho é que há uma complementaridade entre as estimativas feitas por sensoriamento remoto da biomassa vegetal aérea das folhas e dos troncos e galhos. Portanto, considerou-se importante aprofundar o conhecimento que se dispõe sobre a quantificação de biomassa vegetal por meios não destrutivos, dando especial ênfase aos métodos de sensoriamento remoto.

O presente trabalho pretendeu avaliar a utilidade de dois produtos de sensoriamento remoto orbital para estimar a quantidade de biomassa vegetal aérea, tanto foliar quanto lenhosa, em diferentes fisionomias de cerrado. Os métodos de campo também foram divididos em dados sobre folhas e dados sobre tronco e galhos. Assim, diferentes métodos não destrutivos, de campo e de sensoriamento remoto (óptico e por microondas), foram analisados de modo a testar sua utilidade na estimativa de biomassa vegetal em áreas com diferentes quantidades de vegetação. 


\section{2 - Objetivos}

O objetivo geral é verificar se o sensoriamento remoto óptico pode ser utilizado juntamente com o sensoriamento remoto por microondas, na estimativa de biomassa vegetal aérea validada por métodos de campo também não destrutivos.

Os objetivos específicos são:

1. Investigar a existência ou não de relações entre o IAF e os índices de vegetação espectral em faixas do óptico: o IVDN e o IVR, em áreas de cerrado stricto sensu aberto dentro da área de estudo, e determinar as equações que as descrevam.

2. Investigar a existência ou não de relações entre a biomassa aérea em fisionomias florestais do bioma cerrado e o sinal registrado em imagens do radar JERS-1 na área de estudo, e determinar as equações que as descrevam. 


\section{3 - Fundamentos}

A realização deste trabalho envolveu a utilização de imagens de sensoriamento remoto, tanto ópticas quanto de radar, que foram submetidas a diferentes processamentos digitais, como um passo prévio para a extração de informações. Também foi necessário selecionar as áreas amostrais onde posteriormente foram coletados dados no campo.

Considera-se conveniente fazer uma breve descrição do ambiente e da vegetação do cerrado, além de alguns fundamentos de sensoriamento remoto por radar e por sistemas ópticos. Também serão descritas algumas técnicas de processamento digital de imagens e métodos não destrutivos de avaliação de biomassa vegetal.

\subsection{O cerrado}

A vegetação com características fisionômicas de savana que ocorre no Brasil recebe localmente o nome de cerrado, abrangendo várias subclasses (COLE, 1986).

A vegetação do cerrado é constituída basicamente por dois estratos: o arbóreo/arbustivo e o herbáceo, havendo variações locais na determinação dos seus tipos fisionômicos.

Coutinho (1978) define o cerrado como um complexo de formações, que vão desde o campo limpo até o cerradão. Suas formas savânicas (campo sujo, campo cerrado e cerrado stricto sensu) constituem verdadeiros ecótonos de vegetação entre as duas formas extremas: a florestal, representada basicamente pelo cerradão, e a campestre, constituída pelo campo limpo. Ao todo, são reconhecidas cinco fisionomias diferentes, incluindo estes dois extremos: campo limpo, campo sujo, campo cerrado, cerrado stricto sensu e cerradão. O critério para a inclusão em cada classe é a presença, a abundância relativa e o tamanho de arbustos, de árvores e de estrato herbáceo. 
O campo limpo apresenta apenas um estrato herbáceo/subarbustivo, sem árvores nem arbustos. No campo sujo, no campo cerrado e no cerrado stricto sensu, o estrato lenhoso adquire gradativamente maior importância na paisagem. Já o cerradão é uma floresta na qual as copas das árvores se tocam, formando um ambiente sombreado, com estrato herbáceo pouco desenvolvido. Este gradiente biológico é determinado por condições ambientais físicas e recebe o nome de ecoclino.

O cerrado é o bioma brasileiro que ocupa o segundo lugar em extensão, sendo apenas superado pela Floresta Amazônica. Considerando o conjunto das formas fisionômicas que o constituem, o cerrado ocupava aproximadamente 1,8 milhão de quilômetros quadrados, ou seja, quase a quarta parte do território do país, até algumas décadas atrás (COUTINHO, 1990).

A área de concentração do cerrado é o planalto central brasileiro, abrangendo parte dos estados de Minas Gerais, Goiás, Bahia, Mato Grosso, Mato Grosso do Sul, Tocantins e São Paulo (COUTINHO, 1990; INSTITUTO BRASILEIRO DE GEOGRAFIA E ESTATÍSTICA, 1993; KRONKA et al, 1993). A Figura 1 mostra a distribuição dos diferentes biomas no Brasil.

A flora do cerrado consiste de aproximadamente 800 espécies de árvores e arbustos e, freqüentemente, o mesmo número de espécies herbáceas e subarbustivas. Esta vegetação tem características típicas de savana pirofítica. As árvores são retorcidas, baixas e com cortiça grossa e resistente ao fogo. A vegetação do cerrado stricto sensu inclui dois estratos claramente distinguíveis, principalmente nas formas campestres: um estrato arborescente esparso e um estrato herbáceo-arbustivo. O primeiro geralmente permite a penetração da luz. O segundo, formado principalmente por gramíneas e arbustos, é freqüentemente denso e cobre o solo, formando um tapete de 
aproximadamente 30 a $60 \mathrm{~cm}$ de espessura, embora possa atingir até 1,20 m nas etapas reprodutivas (RIZZINI, 1979).

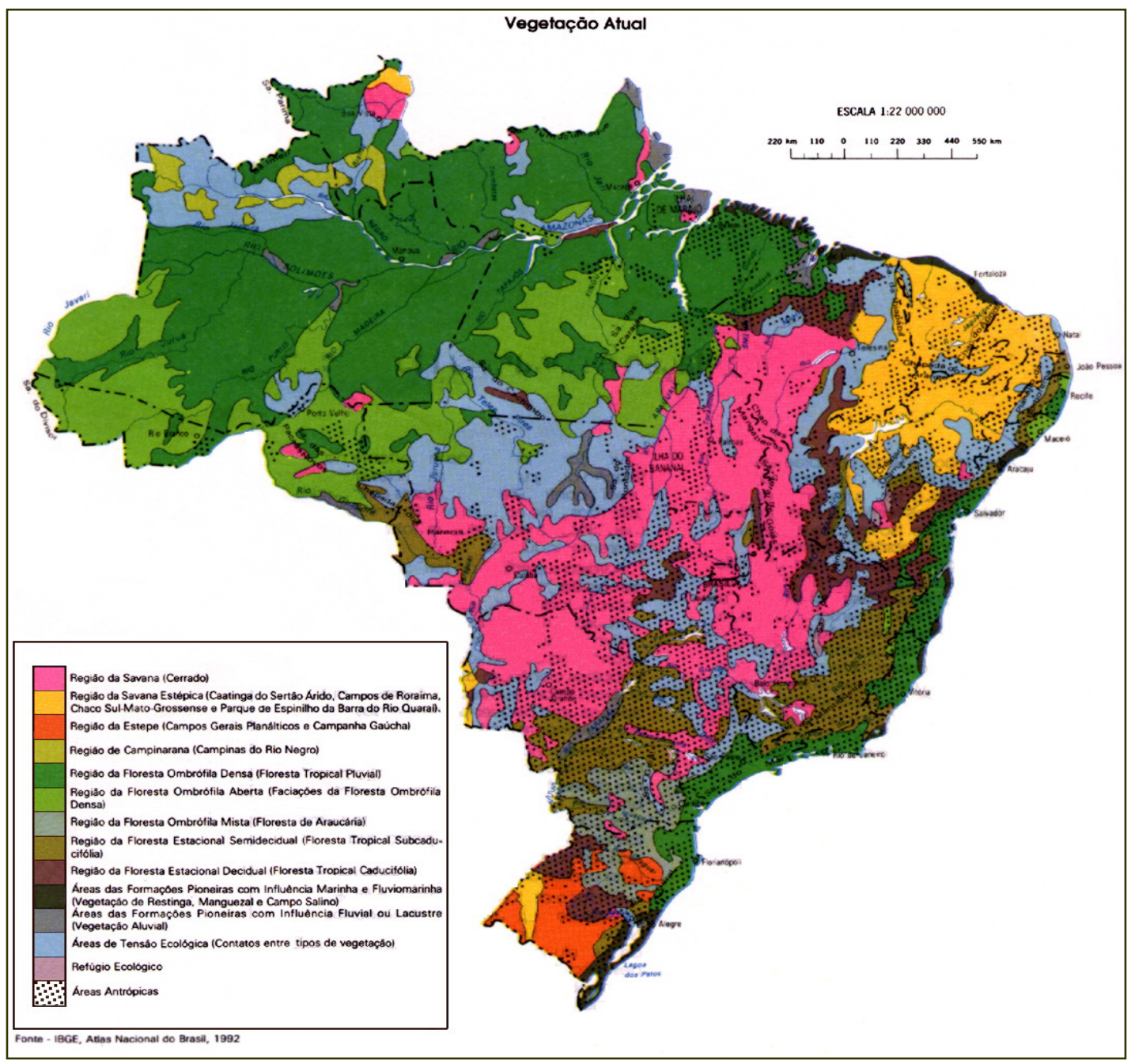

Figura 1. Mapa de vegetação do Brasil. As áreas de domínio do bioma cerrado aparecem representadas na cor rosa. Fonte: Mapa de Vegetação do Brasil, Atlas Nacional do Brasil (IBGE, 1992).

O estrato superior ou arborescente pode ser praticamente inexistente, como no caso do campo limpo, ou pode até dominar a fisionomia, como no cerradão, formação florestal na qual o estrato herbáceo praticamente não existe ou é pouco conspícuo.

Nos casos intermediários, as árvores apresentam adaptações ao ambiente, que lhe permitem sobreviver em condições adversas e completar o ciclo quando elas se tornam favoráveis. A alternância de ciclos entre chuvas e secas é uma característica das áreas 
onde predomina o cerrado, para a qual a vegetação tem se adaptado, desenvolvendo estratégias anatômicas e fisiológicas adequadas (MENIZER et al. 1999). As modificações na anatomia das plantas do cerrado podem ser encontradas tanto na parte aérea quanto na subterrânea. As raízes de muitas espécies de cerrado são comumente bem desenvolvidas e exploram o perfil do solo a grandes profundidades. Dessa forma, ao contrário do que acontece com as florestas secas, a maioria das árvores e arbustos do cerrado continua a transpirar mesmo nos períodos secos.

A distribuição das diferentes fisionomias do cerrado tem sido relacionada a gradientes de fertilidade (ALVIM; ARAUJO, 1952; GOODLAND; POLLARD, 1973), profundidade edáfica, disponibilidade hídrica, ocorrência de fogo e pressão antrópica (COLE, 1960; OLIVEIRA FILHO et al. 1989; PIVELlO; COUTINHO, 1996; MENIZER et al. 1999). Furley (1996), também inclui o fator topográfico entre os determinantes da distribuição da vegetação neste bioma.

Uma das características mais notáveis da vegetação do cerrado é o grande desenvolvimento de órgãos subterrâneos, quando comparado com o desenvolvimento dos órgãos aéreos. Essa estratégia seria um modo das plantas distribuírem a biomassa, de forma a incrementarem a resistência ao fogo (COLE, 1986). Durante a ocorrência de uma queimada, a parte aérea da planta costuma ser destruída, especialmente na vegetação herbácea e subarbustiva (KAUFFMAN et al. 1994). Numerosas plantas do cerrado têm gemas e reservas subterrâneas que lhe permitem emitir novos brotos após a passagem do fogo.

Há casos de espécies, como a Lantana montevidiensis, que precisam da retirada da parte aérea, usualmente pelo fogo, para receber o estímulo que determina o início do processo reprodutivo (COUTINHO, 1990). Essas adaptações levam alguns autores a afirmarem 
que o fogo, longe de ser um elemento alheio e destrutivo do cerrado, forma parte dele e de sua evolução, sendo até mesmo necessário para a conservação deste tipo de vegetação, se manejado de forma adequada (COUTINHO, 1990; MARMORI, 1990). Às vezes, a tortuosidade das árvores do cerrado é atribuída à ação do fogo pela destruição provocada dos brotos terminais, que são mais sensíveis à ação deste agente do que a cortiça. Após a morte deste broto, o vegetal é induzido a emitir novos brotos laterais para substituí-lo, provocando a forma retorcida típica (EITEN, 1972). Nas fisionomias florestais, onde o fogo é menos freqüente, árvores das mesmas espécies apresentam formas mais retilíneas (COUTINHO, 1990).

A capacidade das plantas do cerrado de emitirem brotos axilares é uma estratégia típica que permite a regeneração por rebrote das árvores após terem sido cortadas, originando troncos múltiplos. Além disso, é comum a multiplicação agâmica das plantas com essa característica e a ocorrência de órgãos de multiplicação por essa via, tais como tubérculos, rizomas e sistemas subterrâneos difusos. Eles se espalham em uma área próxima da planta e emitem brotos aéreos, formando touceiras que podem tornar-se independentes, originando assim indivíduos livres (RIZZINI, 1979).

A vegetação do cerrado apresenta freqüentemente características de esclerofilia, assim como folhas com cutículas grossas, estômatos em cavidades, tecidos muito lignificados e, às vezes, silicificados. A vegetação do cerrado freqüentemente apresenta xilopódios, que funcionam como órgãos de reserva e resistência às condições adversas.

A sazonalidade do cerrado é comandada pela alternância entre a época de chuvas e de seca. O estrato herbáceo é o mais influenciado pelo déficit hídrico. As raízes das herbáceas exploram os horizontes superficiais e sub-superficiais do solo. Quando a disponibilidade hídrica torna-se limitante, a parte aérea morre, enquanto as estruturas 
subterrâneas, com capacidade de gerar gemas, mantêm-se vivas. Essas gemas rebrotarão no começo da temporada úmida. Este comportamento provoca o acúmulo de necromassa seca facilmente combustível na superfície do solo, o que facilita queimadas mais freqüentes.

A composição florística do cerrado da porção Sul do domínio apresenta algumas diferenças, tais como distintas adaptações das espécies quando comparada ao cerrado da área central. Também é comum encontrar diferentes tipos de solo e clima entre as duas áreas.

O cerrado é um dos grandes ecossistemas brasileiros que tem sofrido maior devastação devido à ação antrópica, que se remete a épocas anteriores à chegada dos europeus a essas regiões. Entretanto, após o descobrimento, a pressão aumentou gradativamente a ponto de colocar em risco a manutenção da biodiversidade deste complexo fisionômico. A ocupação massiva do cerrado do planalto central teve início na década de 60 , com a construção de Brasília e a abertura de estradas que o atravessam. No início, o maior interesse foi pela madeira, que era convertida em carvão fundamentalmente para abastecer as indústrias siderúrgicas (RATTER et al. 1997).

Os solos do cerrado apresentam baixa fertilidade nas condições nativas. Por esse motivo, nos primeiros anos de ocupação, eram utilizados principalmente para a criação de gado em forma extensiva, valendo-se do estrato graminoso das fisionomias campestres.

A ocupação dessas terras se voltou para a produção agrícola por causa da disseminação de novas tecnologias, que permitiram a correção dos limitantes químicos dos solos. A conseqüente valorização das terras ocupadas pelo cerrado aumentou a substituição da vegetação natural por espécies exóticas com maior valor comercial. 
As condições físicas dos solos do cerrado são favoráveis para a mecanização, porque normalmente são desprovidos de esqueleto pedregoso, além de apresentarem relevos planos a suavemente ondulados e profundos (EITEN, 1972; RIZZINI, 1979). Os cerrados estão localizados sobre solos profundos e antigos. Há muito tempo os solos dos cerrados são conhecidos por sua baixa fertilidade, associada fundamentalmente a suas propriedades químicas. Em geral, eles apresentam elevada acidez, baixa capacidade de troca de cátions (CTC), além de baixa soma de bases e alta saturação por alumínio (FURLEY; RATTER, 1998). Tal elemento, quando se encontra ionizado, apresenta alta toxicidade para a maioria das plantas cultivadas comercialmente. A correção da acidez dos solos do cerrado faz-se usualmente mediante a adição de calcário, provocando assim a substituição dos íons $\mathrm{H}^{+}$por $\mathrm{Ca}^{+2}$. Essa prática provoca a diminuição da acidez, podendo elevar-se o $\mathrm{pH}$ a valores próximos da neutralidade $(\mathrm{pH}=7)$. Neste nível de acidez, o alumínio perde sua toxicidade e a maioria das plantas cultivadas comercialmente atingem seu ótimo. A adição de micronutrientes enriquece o solo com os outros elementos necessários para a nutrição das plantas, possibilitando assim a obtenção de colheitas abundantes. Alguns solos de cerrado costumam apresentar canga, isto é, concreções de óxido de ferro, na superfície ou a pouca profundidade. A canga torna-se uma barreira física para a exploração do perfil do solo pelas raízes, além de impedir a penetração da água de chuva no perfil edáfico. Deste modo, constitui-se em uma dificuldade importante para o uso agrícola. Após a retirada da vegetação nativa e da correção das deficiências químicas, os solos do planalto central brasileiro antigamente ocupados pelos cerrados são responsáveis por $25 \%$ da colheita de grãos do país (CIÊNCIA HOJE, 1997). 
As principais culturas implantadas nestes solos são a soja, o milho, o arroz, a laranja, a cana de açúcar, o café e o reflorestamento por eucaliptos e pinheiros, além das terras destinadas a pastagens para a pecuária de leite e corte. A exploração da madeira da vegetação nativa do cerrado continua até o presente (RATTER et al. 1997).

O cerrado stricto sensu, do ponto de vista da dinâmica do carbono, tem um comportamento sazonal. No período úmido ele funciona como um sumidouro deste elemento, pois absorve mais carbono do que libera, enquanto que no pico da estação seca, funciona como uma fonte, pois libera mais carbono do que absorve. O cerradão, por sua vez, libera carbono no início da estação chuvosa e o absorve no resto do ano (VOURLITIS et al. 2000, apud FERREIRA et al. 2003)

O bioma cerrado é reconhecido como um dos 25 hotspots, áreas com alta concentração de espécies endêmicas e submetidas a processos que ocasionam grande perda de hábitat. Tais áreas foram identificadas como alvos primordiais para a preservação da biodiversidade (MYERS, et al. 2000).

No estado de São Paulo, a área ocupada por fisionomias deste bioma está sobre o aqüífero de Guarani, o mais importante de América do Sul.

A recuperação das áreas do cerrado e sua ampliação seriam fundamentais para a preservação do referido aqüífero e, conseqüentemente, do recurso água potável.

\subsection{Sensoriamento remoto}

Denomina-se sensoriamento remoto a aquisição de informações sobre objetos ou fenômenos na superfície da Terra sem que haja contato direto com eles. O sensoriamento remoto utiliza sensores a bordo de aeronaves ou espaçonaves com o 
objetivo de estudar o ambiente terrestre através do registro e da análise das interações entre a radiação eletromagnética e os objetos que compõem a superfície terrestre.

A diversidade de aplicações do sensoriamento remoto faz com que um número cada vez maior de áreas do conhecimento utilize essa tecnologia. A maior parte dos equipamentos sensores atualmente disponíveis opera nas regiões do espectro eletromagnético do visível, infravermelho e microondas.

O espectro eletromagnético foi dividido, aos fins práticos, em regiões ou intervalos de comprimentos de onda. Esses intervalos costumam ser identificados com nomes específicos os quais estão expostos na Figura 2. O intervalo espectral correspondente aos comprimentos de onda menores, da ordem de ângstrons $\left(10^{-8} \mathrm{~cm}\right)$, é chamado de região dos raios cósmicos. À medida que aumenta o comprimento de onda da radiação, esta é denominada raios gama e raios x. A região chamada ultravioleta inclui a radiação de comprimento de onde entre 300 e 4000 ângstrons. Comprimentos de onda um pouco maiores a este último valor correspondem à porção visível do espectro eletromagnético, que compreende o intervalo de 0.4 a $0.7 \mu \mathrm{m}$, equivalente a 4000 - 7000 ângstrons e a $400-700 \mathrm{~nm}$. No final desta região do espectro começa a região do infravermelho, 0.7 a $100 \mu \mathrm{m}$, a qual costuma ser dividida em três intervalos: infravermelho próximo (0.7 $3.0 \mu \mathrm{m})$, infravermelho médio $(0.7-0.9 \mu \mathrm{m})$ e infravermelho termal $(8-14 \mu \mathrm{m})$. A porção do espectro que inclui a radiação visível e a do infravermelho próximo e médio é denominada região óptica. A radiação contida o intervalo entre 0.1 e $100 \mathrm{~cm}$ é denominada radiação de microondas. Os radares operam com radiação dentro deste intervalo. Radiações com comprimento de onda ainda maior que a do radar estão agrupadas dentro do intervalo denominado ondas de rádio. 


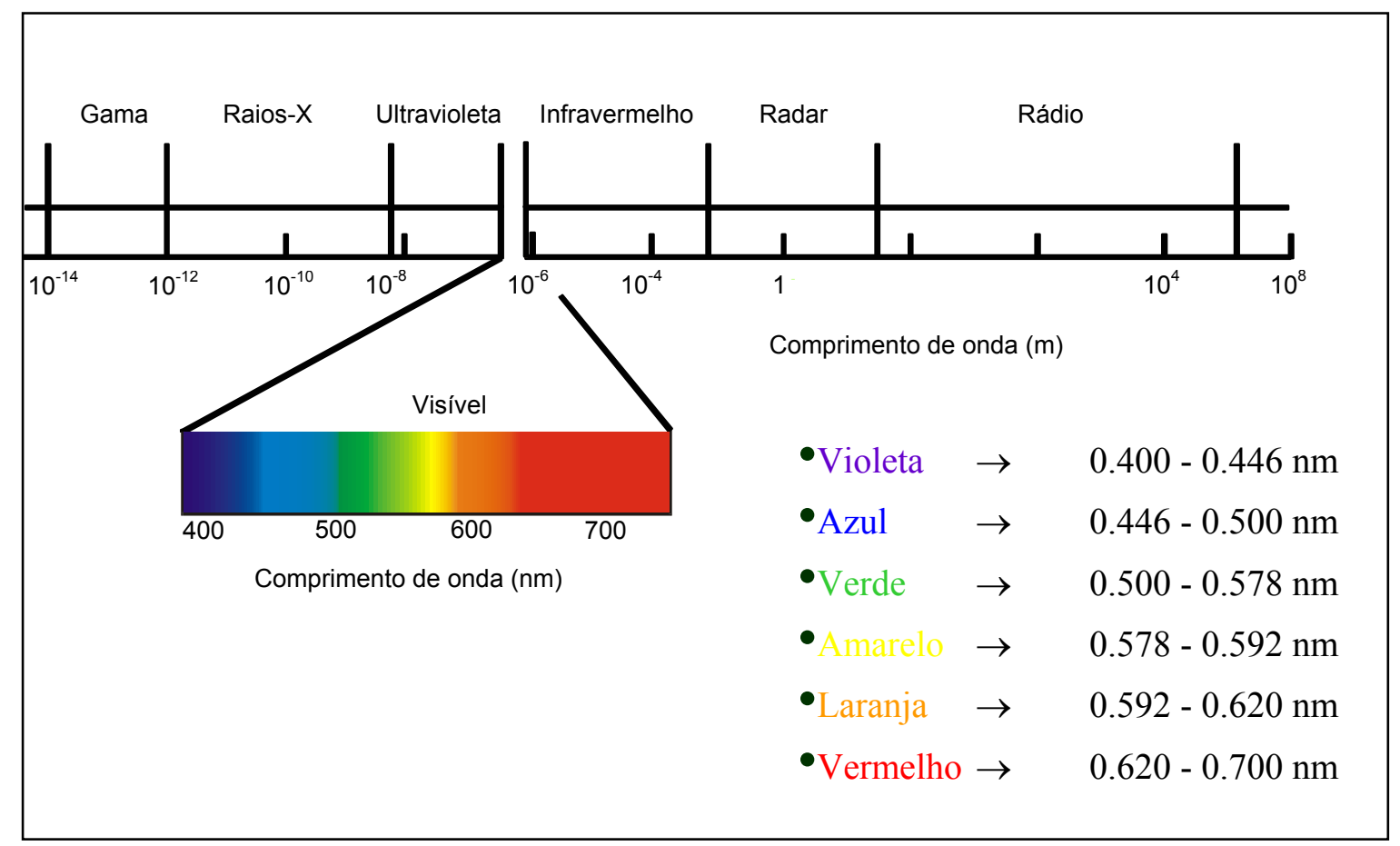

Figura 2. Espectro eletromagnético com a denominação dos diferentes intervalos de comprimento de onda. A região visível encontra-se salientada.

A energia eletromagnética sofre uma série de modificações quando entra em contato com os alvos e interage com eles. Como resultado destas interações, a energia pode ser absorvida, refletida ou transmitida, seja total ou parcialmente. No sensoriamento remoto, a porção da energia refletida em diferentes regiões do espectro é registrada pelos sensores e posteriormente transformada em imagens.

A maioria dos dispositivos geradores de imagens de sensoriamento remoto registra a radiação em diferentes faixas espectrais, gerando uma imagem correspondente à radiação refletida pelos alvos em cada um desses intervalos. Quando um sensor tem a capacidade de obter imagens em diferentes regiões do espectro eletromagnético se denomina sensor multiespectral.

O conhecimento do comportamento espectral dos alvos visados pelos sensores nas diferentes regiões do espectro, assim como a compreensão dos fatores que influenciam 
esse comportamento, é de fundamental importância para a interpretação das imagens. Também é importante para a seleção de processamentos que visem uma eficiente extração de informações das mesmas.

O sensoriamento remoto por radar, opera na região das microondas, em bandas de comprimentos de onda maiores que os da região óptica. $\mathrm{O}$ comportamento espectral dos objetos na região das microondas depende, fundamentalmente, do comprimento de onda da radiação utilizada, das dimensões e do conteúdo de umidade dos objetos.

As imagens de sensoriamento remoto são formadas por uma matriz, cujas células são denominados de pixels (acrônimo do Inglês PICture ELements). Cada um desses pixels possui um valor numérico que corresponde à quantidade de energia refletida pelo alvo dentro de uma faixa determinada de comprimentos de onda. As imagens podem ser georreferenciadas, isto é, cada pixel passa a ter uma coordenada geográfica além de sua coordenada matricial.

\subsubsection{Sensoriamento remoto por sistemas ópticos}

A maioria dos satélites para estudos dos recursos terrestres carrega sensores que operam na porção óptica do espectro eletromagnético: nas faixas do visível e infravermelho próximo e médio. Para a interpretação dos dados na faixa óptica do espectro eletromagnético, é importante um conhecimento prévio do comportamento espectral dos alvos observados, que pode ser visualizado por meio de curvas que representam a variação da reflectância nas diferentes regiões do espectro eletromagnético. Denominase reflectância à proporção da energia incidente, dentro de um intervalo de comprimentos de onda, que é refletida por um alvo. 
O comportamento espectral da vegetação vistoriada pelo sensoriamento remoto óptico está comandado pela presença de pigmentos e de água e pela estrutura do mesófilo das folhas.

O comportamento espectral dos principais alvos de interesse do sensoriamento remoto nessa parte do espectro está mostrado na Figura 3.

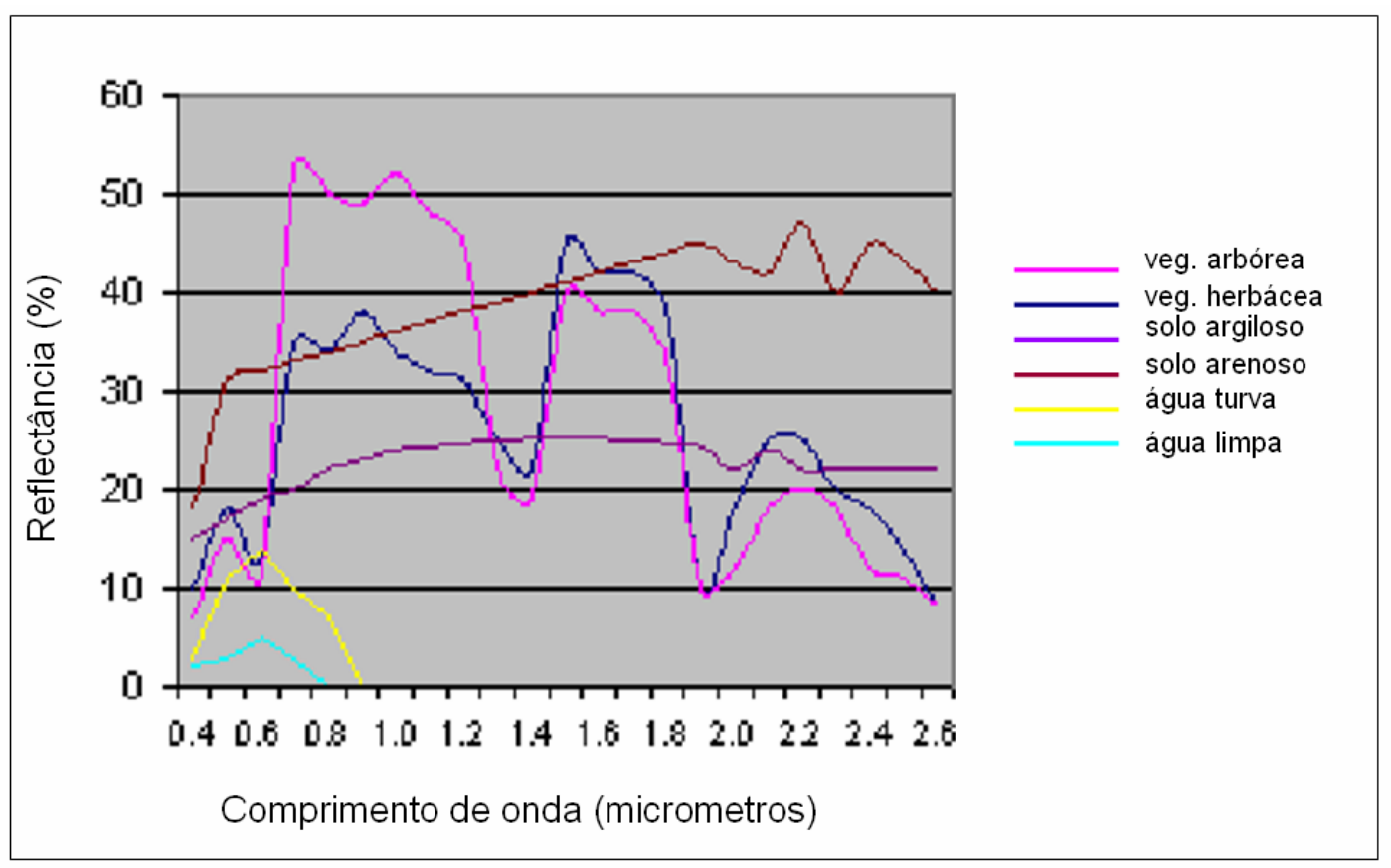

Figura 3. Comportamento espectral dos principais alvos no espectro óptico. São mostrados dois tipos de vegetação, dois tipos de solo e de dois tipos de água. Adaptado a partir de Lillesand; Kiefer (1994).

As folhas da vegetação fotossinteticamente ativa absorvem aproximadamente de 80 a $90 \%$ da energia incidente na faixa do visível ( 0,4 a 0,7 micrômetros). A absorção nessa região do espectro é determinada fundamentalmente pelos pigmentos presentes nas folhas, principalmente pela clorofila. Entre 40 e $80 \%$ da energia no infravermelho próximo ( 0,7 a 1,1 micrômetros) incidente na vegetação fotossinteticamente ativa geralmente é refletida. Este comportamento está determinado pela estrutura do mesófilo 
das folhas. A absorção na zona espectral do infravermelho médio é determinada pela presença de água.

À medida que se incrementa a quantidade de folhas verdes, a reflectância na faixa no visível diminui, enquanto que no infravermelho próximo aumenta, conforme representado na Figura 4. A linha azul escura exemplifica o comportamento espectral de um dossel com poucas folhas verdes. As linhas azul claro, verde e vermelho representam dosséis com quantidades cada vez maiores de folhas verdes.

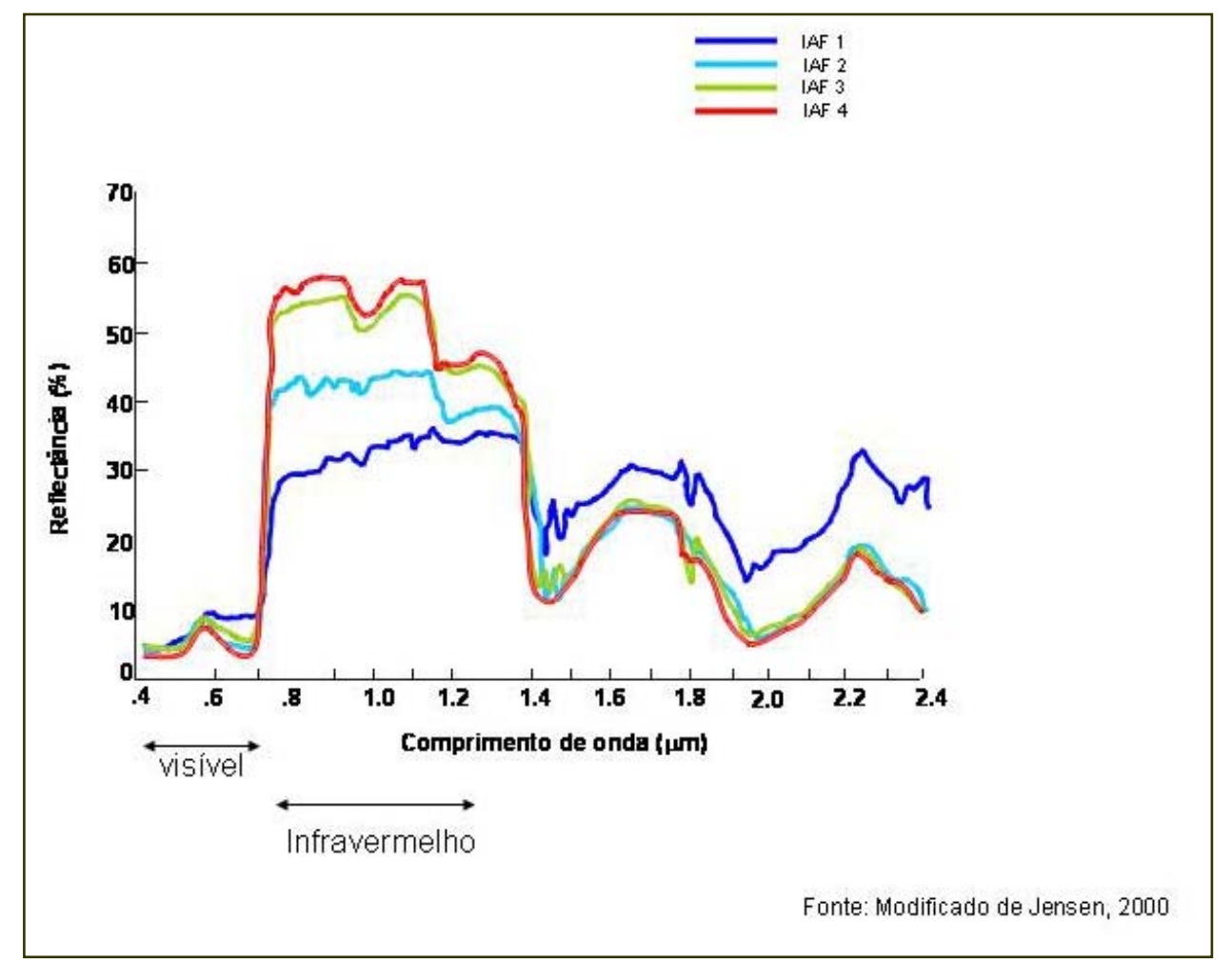

Figura 4. Comportamento espectral de quatro dosséis vegetais com diferentes quantidades de folhas verdes. Modificado a partir de Jensen (2000).

A vegetação morta ou senil apresenta maior reflectância do que a sadia, na faixa espectral do visível, devido à inatividade dos pigmentos responsáveis pela fotossíntese. $\mathrm{Na}$ faixa do infravermelho próximo, a reflectância da vegetação morta diminui, em virtude da degradação do mesófilo. 
O solo geralmente apresenta valores de reflectância intermediários em relação aos apresentados pela vegetação verde e a senil na faixa do visível e valores inferiores aos da vegetação em quaisquer condições na faixa do infravermelho próximo. Alguns fatores modificam o comportamento espectral dos solos. Assim, incrementos tanto no conteúdo hídrico quanto no de matéria orgânica, são responsáveis por uma diminuição da reflectância desses alvos em todas as faixas do espectro óptico. Além disso, os diferentes materiais de origem podem ser responsáveis tanto pelo aumento quanto pela diminuição dessa grandeza (FORMAGGIO et al. 1996).

As imagens ópticas usualmente são fornecidas com os valores dos pixels em números digitais, os quais são adimensionais e não comparáveis com os de outras imagens. É conveniente transformar esses números para alguma grandeza física, geralmente reflectância aparente ou real. A reflectância aparente é aquela que considera a radiação solar que atinge o topo da atmosfera, enquanto que a reflectância real considera a quantidade de radiação que atinge a superfície da terra. As imagens submetidas a essa transformação permitem comparações com outras imagens de distintos locais ou épocas.

Sempre que variáveis sazonais são medidas por sensoriamento remoto, o ideal é utilizar reflectância real, ao invés de número digital, pois as condições de iluminação solar variam ao longo do ano. Segundo Mesquita Jr. (2003), ao usar índices de vegetação para monitorar vegetação semidecídua é conveniente converter a imagem para grandezas físicas.

\subsubsection{1. Índices de vegetação}

O sensoriamento remoto tem se mostrado uma fonte valiosa de dados para estudos da vegetação. Entre outras aplicações do sensoriamento remoto encontra-se o uso de 
imagens índices de vegetação. Matematicamente, as imagens índice de vegetação são modelos numéricos derivados de assinaturas espectrais da vegetação e guardam uma relação direta com a biomassa foliar verde. Nos últimos trinta anos, um grande número de índices de vegetação foi proposto para estimar a quantidade de biomassa fotossinteticamente ativa e espacializar a sua distribuição na superfície da terra.

Os índices de vegetação são algoritmos baseados na transformação de valores de reflectância de determinadas imagens, gerando uma nova imagem com valores do índice em cada pixel. Esses valores podem ser relacionados às características da vegetação, tais como biomassa (BITENCOURT PEREIRA, 1986; DONG et al. 2003; NELSON et al. 2000; SANTOS, 1988; SELLERS, 1986; TUCKER), IAF (VALERIANO; BITENCOURT-PEREIRA, 1989; CARLSON; RIPLEY, 1997; TURNER et. al, 1999; GUPTA; PRASAAD, 2000), extensão das florestas (MAYAUX et al. 1998), porcentagem de cobertura vegetal (HOLBEN; TUCKER, 1980), quantidade de radiação fotossinteticamente ativa (GOWER et al. 1999; VARGAS et al. 2002), produtividade primária e produtividade líquida (LARK; WHEELER, 1999; LIU; KOGAN, 2002).

Os satélites de sensoriamento remoto visitam o mesmo ponto na superfície da Terra em intervalos de tempo pré-estabelecidos. Portanto, podem obter imagens em diferentes períodos ao longo da vida útil do instrumento. Os índices de vegetação têm sido utilizados para estudos da variação sazonal da cobertura vegetal (MESQUITA JR, 1998; MESQUITA JR, 2003) ou para outros processos que requeiram análises multitemporais da vegetação, como por exemplo, o acompanhamento do ciclo de culturas agrícolas.

A maioria dos índices de vegetação está baseada nas diferenças significativas existentes no comportamento espectral da vegetação viva, morta e do solo (JACKSON; HUETE, 
1991). Esta característica torna os índices de vegetação úteis para diferenciar vegetação de solo.

O Índice de Vegetação Diferença Normalizado - IVDN (em Inglês Normalized Difference Vegetation Index - NDVI) foi desenvolvido para salientar o sinal da vegetação fotossinteticamente ativa em condições de pouca biomassa (JACKSON; HUETE, 1991). Dosséis agrícolas, pastagens e áreas vegetadas que apresentam um dossel contínuo, porém pouco volumoso e com marcada sazonalidade, são alvos particularmente adequados para serem monitorados através de imagens que espacializam e quantificam esse índice.

O cálculo das imagens IVDN é realizado com os valores dos pixels das bandas do vermelho e do infravermelho próximo, utilizados como dados de entrada conforme a Equação 1:

$$
\operatorname{IVDN}=\frac{\rho_{\mathrm{IV}}-\rho_{\mathrm{v}}}{\rho_{\mathrm{iv}}+\rho_{\mathrm{v}}}(1)
$$

Onde:

$$
\begin{aligned}
& \rho_{\mathrm{IV}}=\text { valor do pixel na banda do infra-vermelho próximo, } \\
& \rho_{\mathrm{v}}=\text { valor do pixel na banda do vermelho }
\end{aligned}
$$

A Figura 5 representa o processo de elaboração de uma imagem IVDN a partir das bandas do vermelho e do infra-vermelho próximo da área de estudo. 


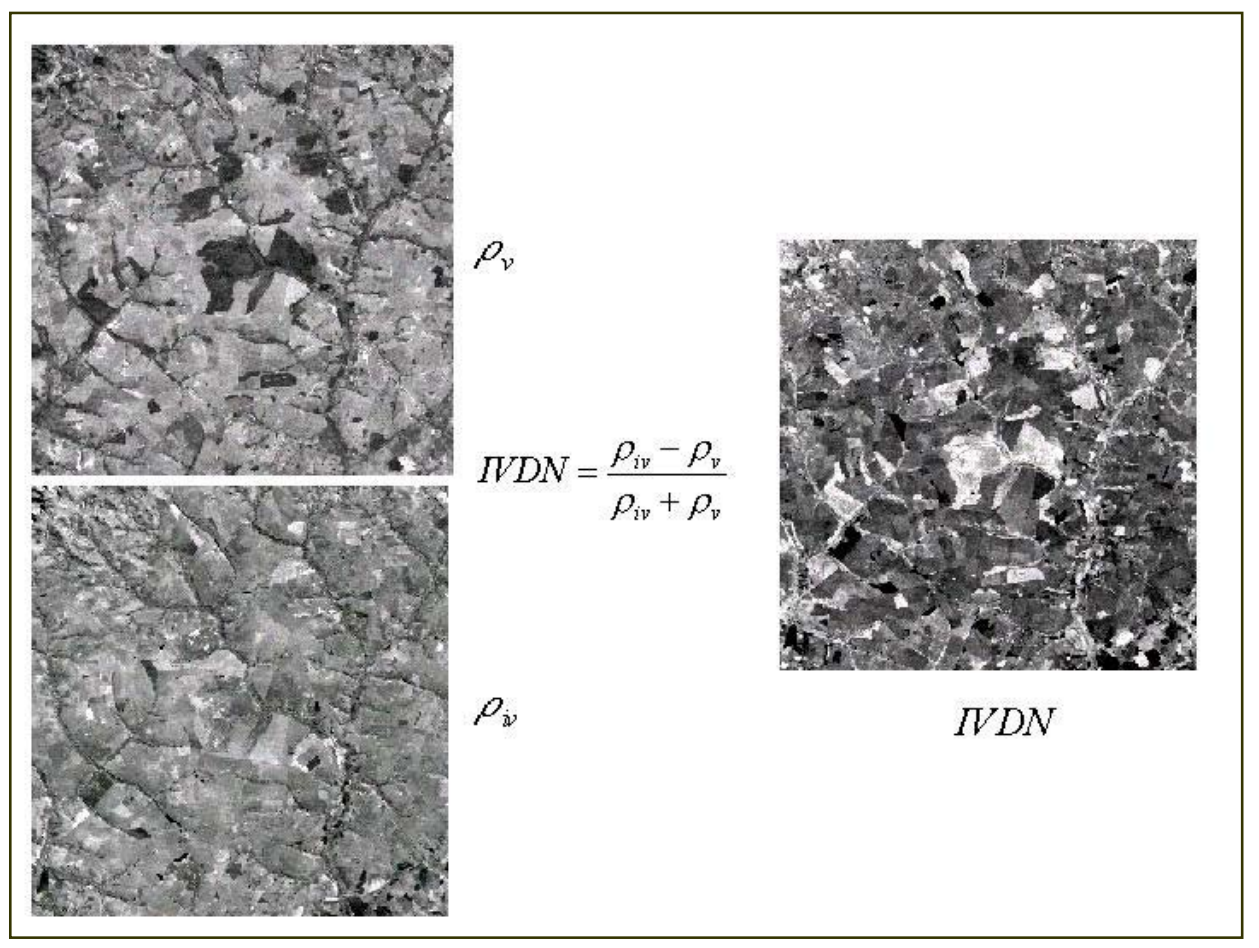

Figura 5. Representação esquemática do cálculo de uma imagem IVDN a partir de uma imagem da região espectral do vermelho e outra da região do infravermelho próximo.

O IVDN também é utilizado para estimar o índice de área foliar (IAF). O IAF é a relação entre a superfície de folhas do dossel e a superfície de sua projeção no terreno (TUCKER, 1979, SANCHEZ-AZOFEIFA et al. 2003).

Entretanto, a alta sensibilidade desse índice a mudanças na quantidade e estado da vegetação se limita às condições de baixa quantidade de biomassa fotossinteticamente ativa (HUETE et al. 1997; JACKSON; HUETE, 1991; LAMBIN, 1999). Como conseqüência, o IVDN perde sensibilidade e satura em condições onde há muita biomassa verde, como é o caso de áreas florestadas. A saturação ocorre quando os valores registrados na imagem IVDN não aumentam concomitantemente aos aumentos na quantidade de biomassa verde (HUETE et al. 1997). O ponto a partir do qual o índice torna-se insensível a incrementos de biomassa verde normalmente encontra-se em torno de valores de IAF dois ou três. 
A Figura 6 mostra o comportamento do IVDN, à medida que se incrementa a quantidade de três diferentes tipos de folhas verdes. A partir dessa figura se deduz que o índice é útil para avaliar a quantidade de vegetação fotossinteticamente ativa em áreas com pouca cobertura vegetal. Também é possível observar a tendência da curva à estabilidade, uma vez que os valores de Índice de Área Foliar (IAF) superam o valor dois ou três.

Embora o IVDN seja o índice de vegetação mais amplamente utilizado em escala global, ele apresenta outras limitações, além do fato de saturar com quantidades baixas de biomassa fotossinteticamente ativa (HUETE et al. 1999). As imagens obtidas no vermelho são grandemente afetadas pela presença de partículas de aerossóis provenientes da queima de vegetais. Em alguns ambientes, tanto antropizados quanto naturais, a ocorrência de queimadas é freqüente e até, em certo grau, previsível. Nas áreas agrícolas, principalmente as destinadas ao cultivo de cana de açúcar, as queimadas são freqüentes na época da colheita. Em áreas destinadas à pecuária, também é freqüente a queima da pastagem na época seca. As partículas que compõem a fumaça têm tamanho similar ao comprimento de onda da luz vermelha, interferindo no sinal registrado nessa faixa pelos sensores orbitais e aerotransportados. Conseqüentemente, o IVDN é sensível à presença de fumaça (MOURA; GALVÃO, 2003). 


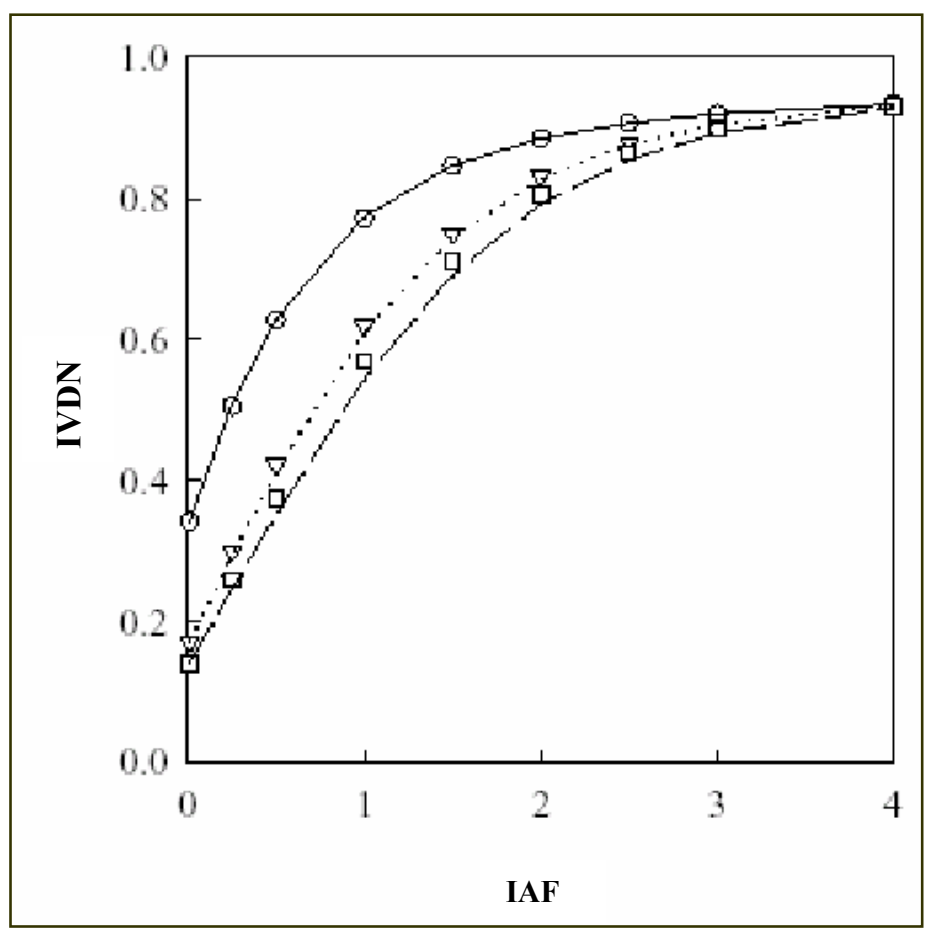

Figura 6. Comportamento do IVDN em relação aos valores do Índice de Área Foliar (IAF). Modificado a partir de Huete et al. (1999).

Vários autores mencionam outros fatores que afetam os valores do IVDN. Entre eles podemos destacar as variações nas propriedades da atmosfera (MIURA et al. 2001); nas características e nas propriedades do solo (GILABERT et al. 2001; HUETE, 1998); a geometria de visada da plataforma que carrega o sensor e as mudanças na geometria de iluminação, devidas fundamentalmente à sazonalidade (HU et al. 2000); o conteúdo hídrico da vegetação (CECCATO et al. 2002); a posição e a largura das faixas espectrais utilizadas (GALVÃO et al. 1999; GALVÃO et al. 2000) e os fatores biofísicos e bioquímicos (ASNER, 1998).

Com o intuito de aprimorar a identificação do estado da cobertura vegetal, novos índices de vegetação têm sido constantemente desenvolvidos (KAUFMAN; TANRÉ, 
1992; STEVEN, 1998; THENKABAIL et al. 2000; GITELSON et al. 2002; HUETE et al. 2002).

No entanto, cada índice consegue compensar a ação de somente um dos fatores mencionados acima, enquanto os outros permanecem sem correção. Assim, dependendo do objetivo do estudo, deve-se selecionar, ou até se desenvolver, um índice adequado que priorize a correção do efeito considerado mais importante.

Em alguns casos, resultados mais precisos têm sido alcançados ao se combinarem mais de um índice de vegetação. Deste modo, Ferreira et al. (2004) obtiveram os resultados mais acurados na separação de diferentes fisionomias de cerrado, na área central do domínio do bioma, combinando os índices IVDN e o Índice de Vegetação Realçado.

O Índice de Vegetação Realçado - IVR (do Inglês Enhanced Vegetation Index, EVI), é um dos poucos índices que consegue diminuir a influência de dois fatores externos ao mesmo tempo. Ele foi desenvolvido com o objetivo de aumentar a sensibilidade das imagens em relação à vegetação em áreas com muita biomassa e, simultaneamente, reduzir a influência da atmosfera nos valores que o índice assume. A alta quantidade de biomassa e os efeitos da atmosfera são os dois fatores principais que limitam a utilização do IVDN (XIAO et al. 2003).

O Soil Adjusted Vegetation Index - SAVI é um índice de vegetação que inclui um termo de correção dos efeitos da contaminação do sinal pelo fundo do dossel, principalmente o ruído originado pelo solo (HUETE, 1998; STEVEN, 1998). O Atmosphere Resistant Vegetation Index - ARVI é outro índice de vegetação que inclui um termo para correção 
dos efeitos atmosféricos (KAUFMAN; TANRÉ, 1992). Portanto, o IVR pode ser considerado um índice de vegetação resultante da junção dos índices ARVI e SAVI.

Conforme Huete et al. (2002), o IVR utiliza os valores de reflectância registrados nas imagens do vermelho, infravermelho próximo e azul, como mostra a Equação 2.

$$
\mathrm{IVR}=\mathrm{G} \frac{\sigma_{\mathrm{IVP}}-\sigma_{\mathrm{V}}}{\sigma_{\mathrm{IVP}}+\mathrm{Cl} * \sigma_{\mathrm{V}}-\mathrm{C} 2 * \sigma_{\mathrm{A}}+\mathrm{L}}
$$

Onde:

$$
\begin{aligned}
& \sigma_{\mathrm{IVP}}=\text { Refletância no infravermelho próximo (banda } 4 \text { ETM+ Landsat) } \\
& \sigma_{\mathrm{V}}=\text { Refletância no vermelho (banda } 3 \text { ETM+ Landsat) } \\
& \sigma_{\mathrm{A}}=\text { Refletância no azul (banda } 1 \text { ETM+ Landsat) } \\
& \mathrm{L}=1 . \\
& \mathrm{G}(\text { fator ganho) }=2.5 \\
& \mathrm{C} 1=6 \\
& \mathrm{C} 2=7.5
\end{aligned}
$$

Esses dois últimos termos são os coeficientes que corrigem a influência dos aerossóis na banda da região espectral correspondente ao vermelho.

O fator L faz um ajuste para compensar a radiação de fundo do dossel. Essa compensação deve ser feita porque a transmissão da radiação, correspondente às faixas espectrais do vermelho e do infravermelho próximo através do dossel vegetal, é diferente e ambas estão relacionadas através de uma equação não linear. 
O IVR é um índice que foi desenvolvido para ser utilizado especificamente com as imagens geradas pelo sensor Moderate Resolution Imaging Spectroradiometer MODIS (HUETE et al. 2002). Esse dispositivo é parte integrante das plataformas orbitais Terra e Aqua do sistema Earth Observation System - EOS. Imagens IVR são um dos produtos fornecidos prontos pelo sistema EOS, que é o organismo da Agência Espacial Norte Americana, NASA, que desenvolveu e opera o sistema.

Imagens IVR MODIS foram testadas no Brasil em condições de grande quantidade de aerossóis resultantes de queimadas (MIURA et al. 2001). Os autores consideraram que o desempenho das imagens utilizadas foi adequado.

\subsubsection{Sensoriamento remoto por radar}

O termo RADAR é um acrônimo das palavras "Radio Detection and Ranging", isto é, detecção em faixas de rádio e medição de distância. Os radares são sensores que operam nas faixas das microondas (freqüências de 0,3 a $300 \mathrm{Ghz}$ ). Eles são denominados sensores ativos, pois emitem radiação eletromagnética e captam a porção dessa radiação que é espalhada pelos alvos na direção do sensor. Em contraste, os sistemas que operam na área óptica do espectro, são denominados passivos, pois registram a energia solar refletida pelos alvos.

O fato de possuir sua própria fonte de energia torna o radar independente da luz solar para a aquisição da imagem. No entanto, os requerimentos energéticos dos sensores ativos são maiores que os dos passivos. Isso ocorre porque os sensores ativos precisam emitir energia suficiente para atravessar a atmosfera e interagir com os alvos. Além 
disso, a parte retroespalhada precisa atravessar novamente a atmosfera até ser captada pela antena do radar a bordo do satélite.

A interação dessa radiação com os alvos é determinada pelas dimensões dos objetos, pela rugosidade da superfície e pela constante dielétrica. Essa última é função do conteúdo hídrico dos objetos. Assim, há radares meteorológicos cuja finalidade é a detecção de nuvens como, por exemplo, o que está localizado no Instituto de Pesquisas Meteorológicas da Universidade Estadual Paulista na localidade de Bauru - SP.

Sob certas condições, o sinal emitido na região espectral das microondas pode penetrar em dosséis vegetais e no solo. Dessa forma, é possível obter informações sobre a superfície da Terra, mesmo que ela se encontre coberta por vegetação. Tal característica permite obter informações do interior dos dosséis vegetais, tornando esses sensores uma ferramenta auxiliar para estudos da superfície terrestre (ULABY et al. 1981).

Os sistemas radar podem gerar imagens ou somente fornecer dados de distância entre o sensor e os objetos. Os sistemas do primeiro tipo, chamados de imageadores, formam uma imagem constituída por uma matriz de pixels. O valor de cada pixel é proporcional à distância entre o sensor e os alvos, às características de rugosidade e à constante dielétrica dos mesmos.

Os radares imageadores de interesse para o sensoriamento remoto diferenciam-se em função da antena utilizada, podendo ser de dois tipos: radares imageadores de abertura real (RAR) e radares de abertura sintética (SAR). As características dos pulsos de radiação emitidos por um sistema RAR são determinadas pelas dimensões reais da antena. Este tipo de sistema emite energia em direção transversal à linha em que se 
movimenta. No imageamento com radares de abertura real, a resolução ao longo da linha de vôo ou resolução azimutal é linearmente proporcional à distância entre o sensor e a superfície. A largura do feixe transmitido é determinada pelo tamanho real da antena. Com isso, há uma limitação na resolução azimutal devido às dimensões da antena, a qual não permite a emissão de grandes feixes de microondas. Essa técnica de imageamento não é utilizada em plataformas orbitais quando o objetivo for obter imagens de alta resolução (ULABY et al. 1981; ELACHI, 1988).

Os radares de abertura sintética (Synthetic Aperture Radar - SAR) são utilizados para melhorar a resolução azimutal. A técnica de abertura sintética de antenas é baseada no fato de que o feixe de radiação emitida permanece sobre o alvo por uma quantidade significativa de tempo. Quando a energia é retroespalhada na direção do satélite, ela é registrada pelo radar a várias posições adiante, ao longo de sua trajetória. O SAR utiliza esse artifício, baseado no deslocamento do satélite, para simular uma antena de dimensão muitas vezes maior que a da antena real, permitindo o uso de uma antena de dimensão compatível com um satélite (ELACHI, 1988).

Os sistemas radar emitem energia eletromagnética que é projetada pela antena em direção à superfície que se deseja imagear. Cada um dos pixels da imagem conterá a quantidade de energia espalhada na direção do sensor a partir de uma unidade de área, a qual é específica para cada sistema. É possível representar a variação da energia espalhada na direção do sensor em uma escala do preto ao branco. Se, nessa escala, o menor valor de espalhamento equivale ao preto e o maior ao branco, as áreas claras representarão feições que espalham grande parte da radiação novamente na direção do sensor. Em contraste, áreas escuras corresponderão a objetos que espalham pouca 
energia na direção do sensor. Como regra geral pode-se afirmar que, quanto rugosa seja uma área na superfície da Terra, mais clara aparecerá representada na imagem de radar e vice-versa.

Outro fator que define o comportamento espectral dos objetos terrestres é o tipo de radiação na qual opera o sensor. Essa radiação encontra-se definida pela freqüência e comprimento de onda. Em geral, pode-se assumir que objetos de tamanho similar ao do comprimento de onda interagem com a radiação emitida pelo dispositivo. Devido a essa interação, o sinal eletromagnético é espalhado em diferentes direções, inclusive na direção do sensor. Esse tipo de espalhamento na direção da fonte é denominado retroespalhamento. É comum encontrar textos que se referem a ele como backscattering, mesmo em Português. A quantidade da energia retroespalhada está relacionada ao parâmetro conhecido como seção transversal de radar. Ele representa a razão entre a energia realmente retroespalhada na direção do sensor e a que seria retroespalhada se a superfície espalhasse a radiação que a atinge de forma homogênea em todas as direções, ou seja, se ela fosse isotrópica (ELACHI, 1988).

A quantidade de energia retroespalhada depende também da polarização considerada pelo sistema. Alguns dispositivos SAR podem transmitir pulsos de energia, tanto polarizados horizontalmente $(\mathrm{H})$ quanto verticalmente $(\mathrm{V})$. Eles também podem ser capazes de receberem e registrarem o sinal refletido na polarização H ou V. Desta forma as combinações possíveis são:

- HH: transmite e recebe na polarização horizontal, por exemplo nos sensores SAR a bordo do satélite japonês Japanese Earth Resources Satellite - JERS-1 e do canadense Radarsat; 
- VV: transmite e recebe na polarização vertical, por exemplo nos satélites europeus da série European Remote Sensing Satellite - ERS;

- VH: transmite na polarização vertical e recebe na horizontal; e

- HV: transmite na polarização horizontal e recebe na vertical.

A cobertura vegetal vem sendo estudada com dados SAR por diferentes pesquisadores (IMHOFF, 1995; LUCKMAN et al. 1997; FOODY et al. 1997; HYYPPA, et al. 2000; QUEGAN et al. 2000; CASTEL et al. 2002; MOREAU; LE TOAN, 2003; WAGNER et al. 2003).

As características das imagens geradas pelo sensor a bordo do satélite ERS (banda C, freqüência 5,3 GHz, comprimento de onda 5,6 cm., polarização VV) em áreas cobertas por vegetação, são devidas à interação da energia com as folhas e ramos pequenos (BERGEN; DOBSON, 1999; HARREL et al. 1995; MOREAU; LE TOAN, 2003). Devido a isso, os dados derivados de sensores que operam nessa região do espectro eletromagnético poderiam ser correlacionados com dados de IAF, em áreas de pastagem ou com escassa vegetação (WARRING et al. 1995; LUCKMAN et al, 1997). Também é possível obter alguma informação do interior da copa das árvores. Em florestas muito jovens, ralas ou com baixos valores de biomassa, é possível que o sinal também inclua alguma contribuição do solo em proporções variáveis, de acordo com as condições da cobertura. À medida que se incrementa a quantidade de biomassa, o número de elementos que interagem com a radiação proveniente do radar aumenta. Conseqüentemente, a contribuição do solo ao sinal retroespalhado diminui até chegar a ser nula. A penetração no interior do dossel é muito baixa e, por esse motivo, se a 
vegetação for muito densa, o sinal carregará primariamente informação do topo do dossel.

O sinal registrado nas imagens geradas pelo sensor SAR a bordo do ERS-1 satura em a partir do valor de biomassa de $20 \mathrm{~T} / \mathrm{ha}$. (IMHOFF, 1995). Para valores de biomassa maiores que o valor de saturação, o comportamento do retroespalhamento é muito estável. É importante, considerar as condições climáticas, pois o conteúdo hídrico sobre as folhas, comumente devido a chuvas ou à condensação de névoa ou de orvalho, pode afetar os valores de retroespalhamento na banda C (WARING, 1995).

No caso do sensor SAR a bordo do satélite JERS-1 (cujas características estão resumidas na Tabela 1) o retroespalhamento e a atenuação do sinal são determinados pelo tamanho e a quantidade de galhos no interior do dossel e pelo arranjo geométrico dos elementos que o compõem (CASTEL et al. 2002, PINHEIRO, 1999). Assim, imagens registradas em esta banda têm informação do interior da vegetação e poderiam fornecer dados da sua biomassa aérea.

Em geral, as folhas não influenciam grandemente o sinal retroespalhado nesta banda devido às dimensões reduzidas desses componentes da vegetação. Mudanças na quantidade de água no exterior das folhas não influenciam os valores de retroespalhamento nas bandas de radar de comprimento de onda maiores, L e P, ao contrário do que ocorre na banda C (WARING, 1995). 
TABELA 1. Características do sensor SAR a bordo do satélite JERS-1. FONTE: Modificado a partir de Xaud (1998) e Hashim et al. (1999).

\begin{tabular}{cc}
\hline ITEM & PARÂMETROS \\
\hline Freqüência & $1,275 \mathrm{GHz}$ \\
Polarização & $\mathrm{HH}$ \\
Resolução & $18 \mathrm{~m}$ \\
Banda & $\mathrm{L}$ \\
Comprimento de onda & $23,5 \mathrm{~cm}$ \\
\hline
\end{tabular}

Em casos de áreas com baixa quantidade de biomassa, a radiação emitida pelo radar consegue atravessar o dossel vegetal e interagir com o solo. Desta forma, o sinal retroespalhado também inclui alguma informação do substrato. À medida que se incrementa a quantidade de biomassa, aumentam os valores de retroespalhamento, de forma logarítmica, até atingir um limiar. A partir desse limiar, o sinal satura, sendo que novos incrementos no valor de biomassa não ocasionam incrementos no valor do sinal retroespalhado. Essa relação entre as duas grandezas tem sido utilizada para estimar os valores de biomassa a partir dos valores de retroespalhamento contidos em imagens de radar da banda L (WAGNER et al. 2003).

Vários estudos mencionam diferentes valores de limiares de biomassa lenhosa aérea aos quais a resposta das microondas em sistemas SAR na banda L se estabiliza. Assim, Imhoff 1995 (apud SANTOS et al. 2002) propõe um limiar de 40 T/ha. Luckman et al. (1997); Luckman et al. (1998) e Santos et al. (2000) propõem um valor superior de 60 T/ha. Já Araujo et al. (1999), Kasischke et al. (1997) e Sun et al. (2002) sugerem um valor de 100 T/ha. Por outro lado Ranson et al. (1997) propõem 150 T/ha. e Austin et al. (2002) afirmam ter estimado valores de até $700 \mathrm{~T} / \mathrm{ha}$ ao trabalharem com imagens JERS-1 em uma floresta de eucaliptos na Austrália. 
A Figura 7 representa esquematicamente a interação da radiação, emitida por radares que operam em diferentes bandas de comprimento de onda, com o dossel vegetal de uma floresta. Quanto maior for a penetração da radiação no interior do dossel, maior será a quantidade de informação dos troncos e galhos carregada pelo sinal retroespalhado. Por outro lado, quanto menor for a penetração da radiação no dossel, maior será a contribuição das folhas e galhos no total de informação retroespalhada que o sensor registrará.

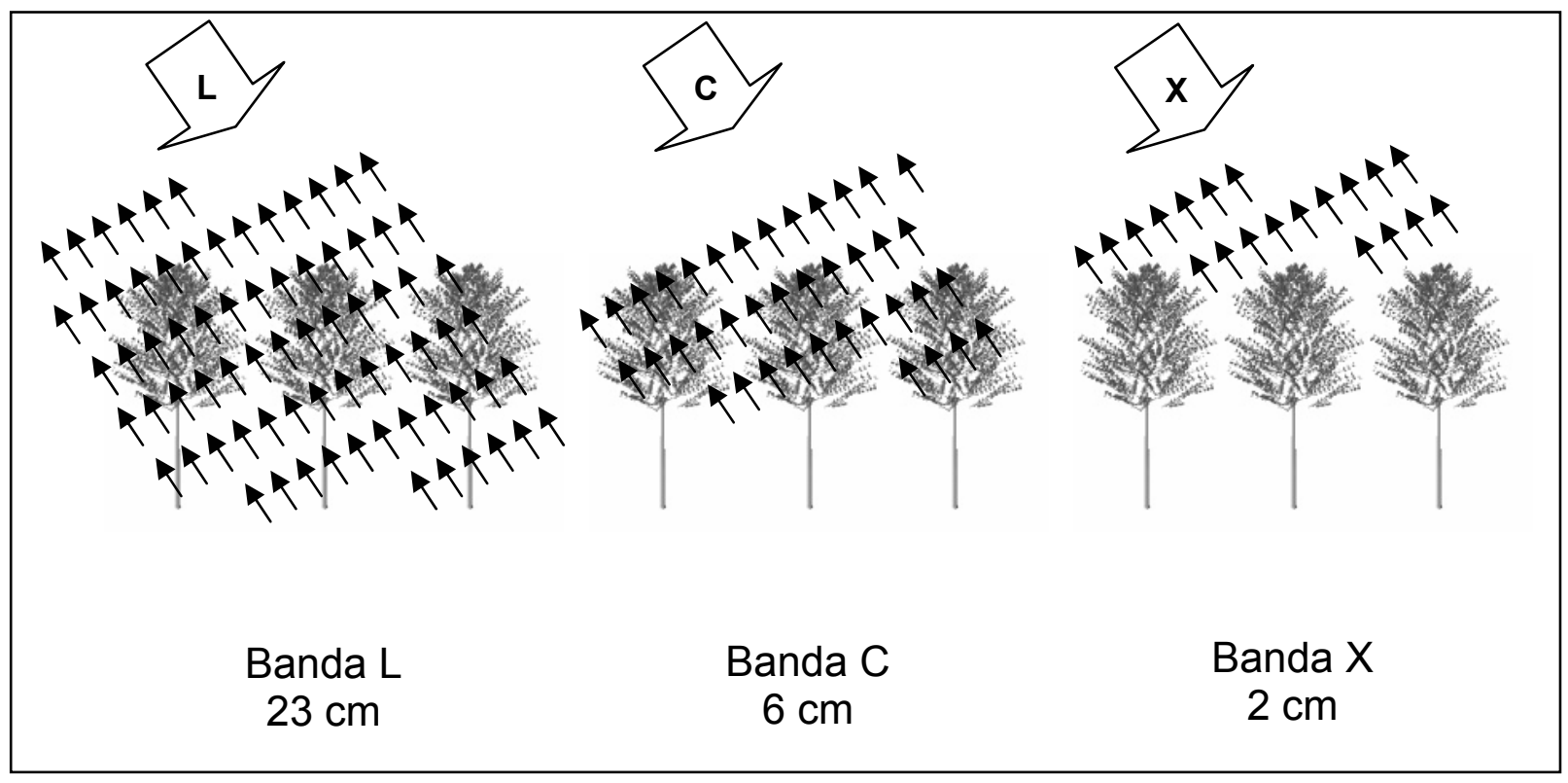

Figura 7. Interação das microondas das bandas L, C e X, com o dossel vegetal de uma floresta. São mostrados os valores de comprimentos de onda de cada banda. Adaptada de Dallemand et al. (1991).

A utilização de polarizações cruzadas (HV ou $\mathrm{VH})$ tem se mostrado promissória na tarefa de estimar biomassa aérea de áreas florestais (LUCKMAN et al. 1997). No entanto, os sensores que atualmente operam nessas polarizações são aerotransportados ou carregados a bordo de naves espaciais (SIR-C/X). Esses dispositivos operam por um limitadíssimo período de tempo. Por esse motivo, ficam restritos ao campo da pesquisa. 
A Tabela 2 apresenta a freqüência e o comprimento de onda das principais bandas utilizadas para sensoriamento remoto por radar.

TABELA 2. Freqüência e comprimento de onda das principais bandas utilizadas em sensoriamento remoto por radar. Adaptada de Xaud (1998).

\begin{tabular}{ccc}
\hline Banda & Freqüência & Comprimento de onda \\
\hline $\mathrm{P}$ & $0,4-1 \mathrm{GHz}$ & $30-75 \mathrm{~cm}$. \\
$\mathrm{L}$ & $1-2 \mathrm{GHz}$ & $15-30 \mathrm{~cm}$. \\
$\mathrm{S}$ & $2-4 \mathrm{GHz}$ & $7,5-15 \mathrm{~cm}$. \\
$\mathrm{C}$ & $4-8 \mathrm{GHz}$ & $3,7-7,5 \mathrm{~cm}$. \\
$\mathrm{X}$ & $8-12 \mathrm{GHz}$ & $2,5-3,7 \mathrm{~cm}$. \\
\hline
\end{tabular}

\subsection{Tratamento de imagens}

As imagens de sensoriamento remoto permitem extrair numerosas informações sobre a cobertura da superfície terrestre. No entanto, freqüentemente é necessário submetê-las a diferentes tipos de tratamentos que objetivam incrementar as possibilidades de extração dessas informações. Esses tratamentos podem ser corretivos ou de transformação dos números digitais em índices.

\subsubsection{Tratamento de imagens ópticas: correção atmosférica}

$\mathrm{O}$ número digital de cada pixel que formam as imagens ópticas inclui a influência da atmosfera, juntamente com informações da superfície da Terra. Dependendo do objetivo do trabalho e das informações extraídas das imagens, é necessário submetê-las a processamentos que visam diminuir essa influência da atmosfera. Isso é particularmente importante quando se pretende comparar a evolução de algum processo que se desenvolve ao longo do tempo. Nesses casos, as condições da atmosfera na data de 
aquisição de cada imagem, quase certamente, não são as mesmas e a contribuição destes efeitos será diferente para cada data, tornando os valores dos pixels não comparáveis (ZULLO et al. 1994).

A atmosfera altera os valores registrados pelos sensores orbitais por meio de dois processos principais: o espalhamento Mie e o Rayleigh. O tipo de espalhamento que atua depende, principalmente do tamanho das moléculas de gás ou das partículas de aerossóis presentes na atmosfera.

Quando a radiação é espalhada por partículas cujos raios se aproximam ou excedem em até aproximadamente oito vezes o seu comprimento de onda, o espalhamento preponderante é o Mie. Esse processo independe do comprimento de onda e por isso é denominado espalhamento não-seletivo. Portanto, a radiação é espalhada igualmente em todos os comprimentos de onda. As partículas que compõem os aerossóis atmosféricos espalham a radiação solar desta maneira.

O espalhamento por partículas cujo raio é bem menor que o comprimento de onda da radiação espalhada, como o caso do espalhamento da luz visível por moléculas de gás da atmosfera, é inversamente proporcional à quarta potência do comprimento de onda. O espalhamento Rayleigh determina assim a dispersão da radiação de menor comprimento de onda.

\subsubsection{Método do pixel escuro}

Vários são os métodos utilizados para diminuir os efeitos da atmosfera em imagens adquiridas na faixa óptica do espectro eletromagnético. Chavez (1988), desenvolveu o método do pixel escuro, baseado em que algumas áreas deveriam apresentar reflectância zero e que qualquer valor diferente desse registrado na imagem é devido à influência da 
atmosfera. Neste método de correção, áreas sombreadas ou com água limpa e profunda são identificadas, determinando-se a seguir os valores de reflectância dos pixels dessas áreas em cada banda e utilizando-se esses valores para corrigir as demais áreas.

\subsubsection{Modelo 6S}

Nos últimos anos, os métodos de correção que se baseiam em modelos de transmissão atmosférica têm sido utilizados (TANRE et al. 1990; VERMOTE et al. 1997; ZULO Jr, 1994).

O modelo Second Simulation of Satellite Signal in the Solar Spectrum -6S (VERMOTE et al. 1997), permite estimar a reflectância, ou seja, a proporção da energia solar incidente na superfície da terra que é refletida pelo sistema atmosfera/superfície-dosolo, como é observado pelos satélites no intervalo do espectro $0,25 \mu \mathrm{m}$ a 4,00 $\mu \mathrm{m}$.

O modelo permite calcular a reflectância real de cada pixel em uma imagem, considerando os efeitos de absorção pelos gases ozônio e vapor de água e de espalhamento por moléculas e aerossóis. O modelo $6 \mathrm{~S}$ requer vários parâmetros de entrada, tais como: o comprimento de onda da banda que será corrigida cada vez que ele for executado, hora, dia e mês de aquisição da imagem, latitude e longitude do centro da cena, condições da atmosfera.

Quando não se dispõe dos dados relativos à condição da atmosfera no lugar e momento de aquisição da imagem, existe a possibilidade de utilizar um modelo atmosférico que simule estas condições. $\mathrm{O}$ critério se baseia em selecionar o que mais se assemelhe às condições predominantes no local durante a aquisição da imagem. Por meio destes modelos, é possível introduzir os valores padrão pré-estabelecidos para algumas das 
situações mais usuais. Os modelos implementados no 6S são: "tropical”, "verão em latitudes médias" e "inverno em latitudes médias".

Uma outra variável que o 6S considera ao corrigir as imagens é a profundidade óptica para aerossóis. Ela está determinada pelo tipo e pela concentração de aerossóis na atmosfera e é utilizada pelo modelo para corrigir o espalhamento Rayleigh. Os valores relacionados ao tipo de aerossóis da atmosfera também podem ser introduzidos, se os dados das condições particulares de aerossóis atmosféricos no local e momento da aquisição da imagem estiverem disponíveis. Outra possibilidade seria selecionar os valores de profundidade óptica a partir de um conjunto de modelos pré-estabelecidos. Deste modo, em áreas marítimas ou litorâneas, deve-se selecionar o modelo marítimo; já em áreas afastadas do mar, deve-se selecionar o modelo continental. Áreas urbanas possuem um modelo específico. Além disso, há também a alternativa de considerar uma atmosfera com ausência de aerossóis.

A concentração dos aerossóis é comumente estimada a partir da espessura óptica ou a partir da visibilidade. A espessura óptica dos aerossóis que o modelo considera é estabelecida na região do espectro de $550 \mathrm{~nm}$. Esse dado é fornecido pela página do sensor MODIS (MODIS, 2003) diariamente para o mundo todo. Outra opção é estimar a espessura óptica a partir da visibilidade em quilômetros.

O sistema 6S fornece imagens de saída corrigidas dos efeitos da atmosfera e em reflectância real, adimensionais 


\subsubsection{Tratamento de imagens de radar}

As imagens de sensoriamento remoto por radar, utilizadas para monitoramento de recursos naturais, são registradas em bandas espectrais que não sofrem influência da atmosfera. Por isso, essas imagens não necessitam de correções atmosféricas.

A transformação dos valores da imagem de número-digital a decibéis $(\mathrm{dB})$ permite obter valores comparáveis entre diferentes períodos de tempo. Tal conversão de unidades implica em uma transformação logarítmica segundo a Equação 3 (ROSENQVIST, 1996):

$$
\sigma=10 \log _{10}\left[\frac{\sum\left(\mathrm{ND}^{2}\right)}{\mathrm{n}}\right]+\mathrm{CF}
$$

onde:

DN: Número digital do pixel

CF: Fator de calibração -85,34 (SHIMADA, 2002)

n: Número de pixels considerados

No sistema de geração de imagens de radar utilizado pela Agência Espacial Japonesa, NASDA, os valores do coeficiente CF necessários para transformar os valores dos pixels de número-digital para $\mathrm{dB}$ não são constantes ao longo do tempo. O valor desse coeficiente é fornecido pela NASDA para diferentes períodos. A Tabela 3 fornece os valores do CF para quatro intervalos de tempo. A imagem JERS-1 SAR utilizada neste trabalho foi processada pela NASDA em 4 de setembro de 2000, por isso o valor do coeficiente que foi utilizado é $-85,34$. 
TABELA 3. Valores do coeficiente CF para diferentes períodos de tempo. Fonte: Shimada, 2002.

\begin{tabular}{cc}
\hline Data de processamento & Valor do CF \\
\hline Até 14 de fevereiro de 1993 & $-70,0$ \\
Após 15 de fevereiro de 1993 & $-68,5$ \\
Após 1 de novembro de 1996 & $-68,2$ \\
Após 1 de abril de 2000 & $-85,34$ \\
\hline
\end{tabular}

\subsection{Métodos não destrutivos de avaliação de biomassa vegetal}

Entre os métodos não destrutivos de determinação de biomassa vegetal, estão os que se baseiam na modelagem de algumas relações biofísicas, conhecidas como equações alométricas. Uma relação é denominada alométrica quando uma característica física ou fisiológica sofre variação de acordo com o tamanho do organismo (BEGON et al. 1986). O sensoriamento remoto, tanto na região óptica quanto na região das microondas, também permite estimar a quantidade de biomassa vegetal de forma não destrutiva.

\subsubsection{Equações alométricas}

A alometria de árvores, isto é, as relações entre tamanho e forma, apresentam um relevante efeito na estrutura e funcionamento da floresta. $\mathrm{O}$ tamanho, o formato e a posição da copa de uma árvore relacionam-se com a quantidade de luz interceptada. Já as dimensões do tronco estão relacionadas à sua resistência mecânica frente às forças, tais como o vento e a massa da copa (KING, 1996).

$\mathrm{O}$ uso de equações alométricas tem adquirido importância pela rapidez, baixo custo e relativa precisão dos resultados que elas fornecem. As equações alométricas mais simples são as que consideram apenas um elemento da árvore para estimar a sua 
biomassa. Assim, uma alternativa é medir a circunferência à altura do peito (CAP), diâmetro à altura do peito (DAP) ou a altura da árvore em questão, determinando sua biomassa através de fórmulas, tabelas ou curvas (SCOLFORO; MELLO, 1997). Este método, apesar das vantagens mencionadas, fornece dados pouco precisos. A aplicação desta metodologia limita-se usualmente a levantamentos em áreas de florestas implantadas mono-específicas e nos casos em que o grau de precisão esperado não seja alto, por exemplo, durante um levantamento expedito para obter estimativas gerais de recursos florestais existentes em uma área. No entanto, há casos nos quais essa metodologia é utilizada para quantificar a biomassa de florestas naturais.

Burrows et al. (2002), determinaram uma função que relaciona área basal média com biomassa em uma área de savana com eucaliptos na Austrália. Os autores concluiram que a metodologia forneceu dados confiáveis para a quantificação de biomassa florestal aérea, mesmo em um ambiente florestal multi-específico.

A inclusão de outros parâmetros nas equações permite incrementar a precisão das estimativas de biomassa. Geralmente, os parâmetros mais utilizados neste tipo de algoritmo são: a altura e o DAP ou o diâmetro na base (DB) (BROWN et al. 1989; KING, 1996; ABDALA et al. 1998; SPECHT; WEST, 2003).

Ottmar et al. (2001), desenvolveram uma metodologia para quantificar a biomassa da vegetação do cerrado do Brasil central usando pares de fotografias estereoscópicas. O objetivo desse trabalho foi avaliar a quantidade de combustível disponível por unidade de área, em diferentes fisionomias e condições da área central do domínio do Cerrado. Os autores selecionaram cinco áreas, cada uma com condições típicas de fisionomias e de quantidade de combustível. Eles tomaram pares estereoscópicos de fotografias de 
cada uma dessas áreas. Essas fotografias estão disponíveis em um manual de campo, no qual também se incluem informações sobre a composição, estrutura e biomassa da vegetação, a necromassa lenhosa acumulada e a serapilheira. A metodologia proposta consiste em selecionar as fotografias correspondentes à área mais similar com a que se pretende avaliar. Desta forma, é possível estimar a biomassa por comparação com as fotografias disponíveis no manual.

Essas metodologias fornecem dados de biomassa vegetal dentro de certos limites de precisão, devendo-se decidir se esses limites são aceitáveis em cada situação, segundo o objetivo do trabalho. No entanto, quando são necessários dados de biomassa no nível regional, tal metodologia torna-se impraticável, já que a obtenção de valores confiáveis nessa escala demandaria excesso de mão de obra e de tempo de medição em campo.

\subsubsection{Métodos de amostragem da vegetação florestal}

Há vários métodos aplicados em campo para selecionar os indivíduos a partir dos quais deverão ser coletados os dados de interesse (MATTEUCCI; COLMA, 1982). Em todos os casos os critérios de inclusão devem ser definidos antes do levantamento. Portanto, é comum estabelecer um valor limiar de inclusão de diâmetro do caule a 1,30 m da altura do solo ou à altura do peito (DAP), ou então considerar o diâmetro na base do caule (DB), a partir dos quais os indivíduos seriam incluídos no levantamento. Às vezes, indivíduos pertencentes a determinados taxa, também são excluídos, freqüentemente palmeiras e fetos arborescentes, dependendo do objetivo do levantamento.

O censo é o método que fornece dados mais próximos da realidade no campo, porque todos os indivíduos existentes são identificados e medidos. Esse método, embora 
forneça boa qualidade de informação, apresenta a desvantagem de consumir muito tempo e mão de obra.

Entre os métodos que consideram um subconjunto dos indivíduos através de diferentes técnicas de amostragem, os métodos de área fixa ou parcelas são os que representam de forma mais precisa quali e quantitativamente a vegetação, porque fornecem valores mais próximos da realidade.

Outro conjunto de métodos de amostragem de plantas está constituído por aqueles baseados em distâncias, sendo uma alternativa àqueles baseados em parcelas. Os primeiros apresentam algumas vantagens quando comparados aos de área fixa, pois são mais eficientes em termos de volume de resultados por unidade de tempo.

Em geral, os levantamentos por meio de métodos baseados em distâncias são mais rápidos, pois requerem menos equipamentos e mão de obra, além de não exigirem o ajuste da área de amostragem para as diferentes situações de densidade encontradas nas áreas de estudo (COTTAM; CURTIS, 1956).

O método de quadrantes é um dos métodos baseados em distâncias mais utilizados para os levantamentos em fisionomias florestais (MANTOVANI, 1993). O procedimento para amostrar os indivíduos florestais através desse método consiste em dividir as áreas a serem amostradas em quatro sub-áreas, denominadas quadrantes, com limites ortogonais entre si. Considera-se a árvore mais próxima da origem dos eixos em cada quadrante que satisfaça os quesitos pré-estabelecidos (forma de vida, diâmetro ou perímetro do caule a 1,3 m de altura do solo ou na base do caule, táxons etc.) e coletamse os dados de interesse, normalmente altura máxima e do fuste, DAP ou DB, 
identificação taxonômica e distância a partir do ponto de origem dos eixos que determinam os quadrantes.

No método de pontos quadrantes, destacam-se duas variações principais: centrado em um ponto e centrado em uma árvore (MANTOVANI, 2001).

No primeiro, esquematizado na Figura 8, utiliza-se a simulação de um quadrante, formado por dois eixos do mesmo tamanho perpendiculares e unidos no centro, que é lançado assistematicamente na superfície da área de estudo. As hastes do instrumento delimitam no solo os quatro quadrantes em que serão amostradas as árvores. Dentro de cada quadrante, coletam-se as medidas da árvore mais próxima ao centro de interseção dos eixos e que cumpra os critérios de inclusão determinados previamente. Essa variação do método tende a superestimar o número de árvores presentes na área (MARTINS, 1993).

O método de quadrantes centrado em uma árvore, esquematizado na Figura 9, é similar ao anterior, mas difere por não utilizar um instrumento, pois seleciona uma árvore que será a referência para traçar os eixos que delimitarão os quatro quadrantes no campo. A árvore central é considerada no levantamento somente como centro do quadrante, ou seja, que não se determina sua altura, DAP, nem sua identificação botânica. Em ambos métodos, é preciso considerar que a distância entre os quadrantes deve ser suficiente para garantir que nenhuma árvore seja contabilizada duas vezes. 


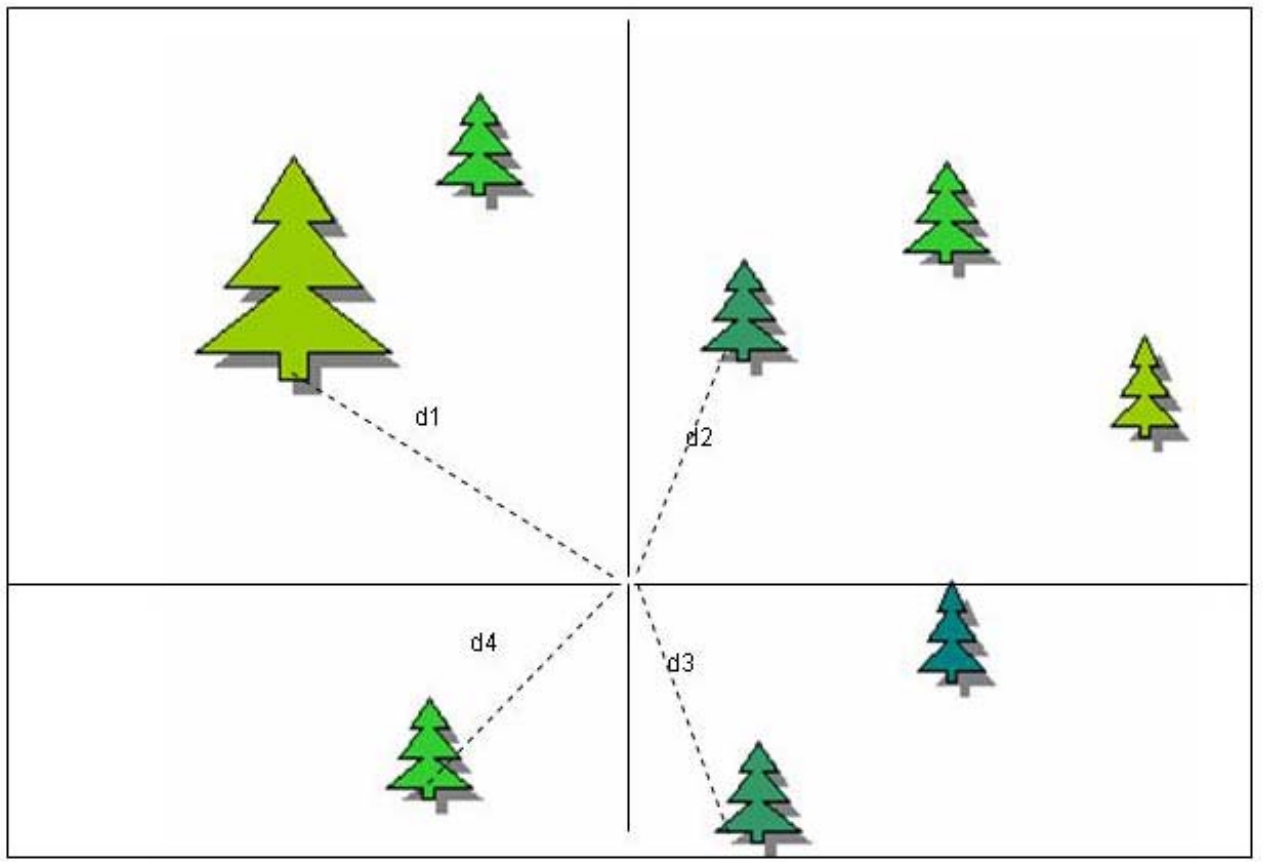

Figura 8. Amostragem de vegetação florestal pelo método do quadrante centrado num ponto.

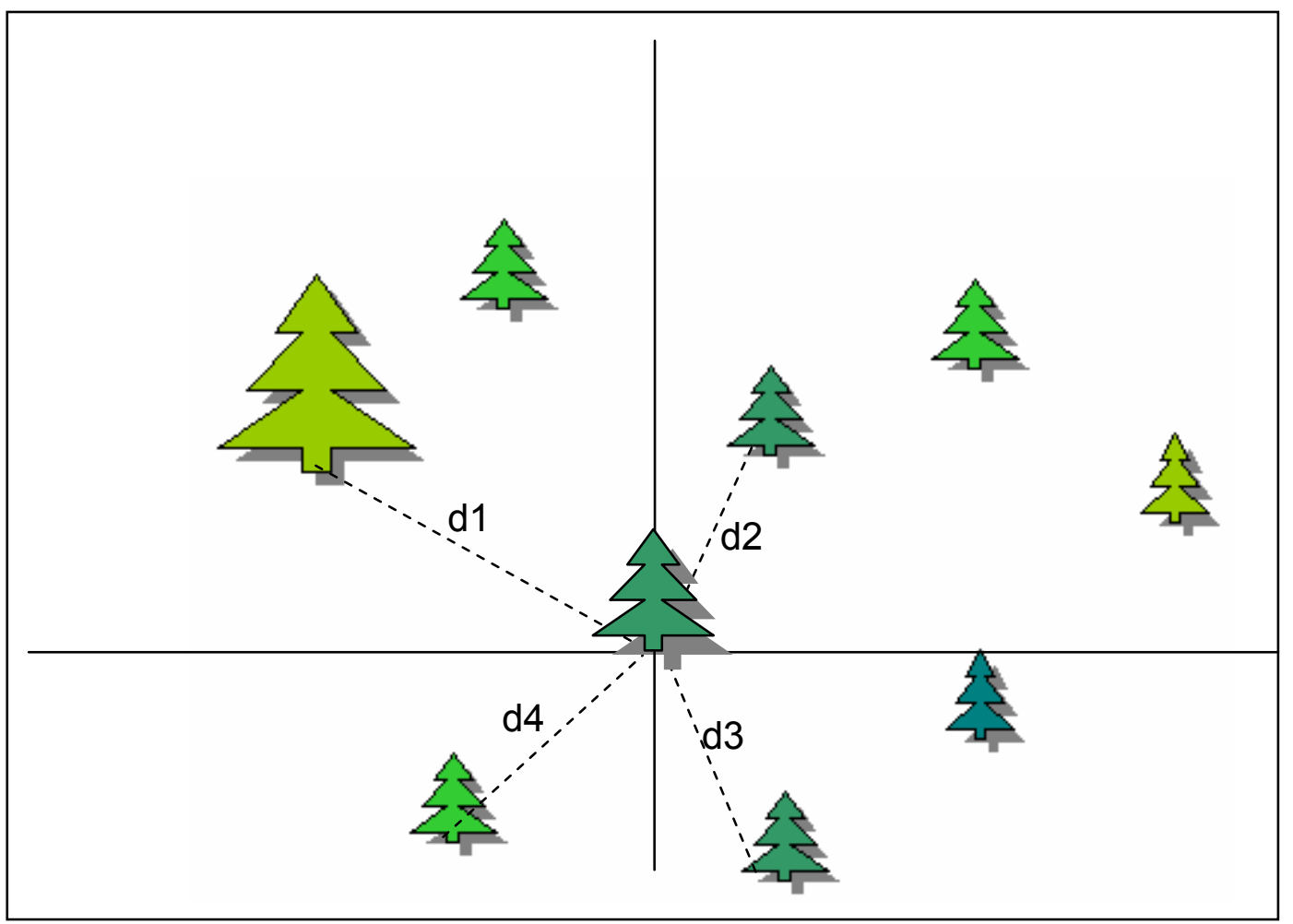

Figura 9. Amostragem de vegetação florestal pelo método do quadrante centrado numa árvore. 
As equações alométricas fornecem valores de peso de árvores $\left(\mathrm{p}_{\mathrm{i}}\right)$. O cálculo de biomassa por unidade de área exige que esses valores sejam relacionados à superfície que os contêm. No caso da amostragem da vegetação utilizando métodos de parcelas, o cálculo da biomassa é direto, devendo dividir-se o peso das árvores contidas dentro da parcela pela área da mesma.

O cálculo de biomassa por unidade de área em levantamentos realizados pelo método de quadrantes é feito pela Equação 4:

$$
\begin{gathered}
\frac{\left(\sum \mathrm{d}\right)}{\mathrm{n}}=\mathrm{d}_{\text {med }}(4) \\
\left(\mathrm{d}_{\mathrm{med}}\right)^{2}=\mathrm{A}=\text { Área média }
\end{gathered}
$$

Onde:

$\mathrm{n}$ = número total de árvores amostrados em cada área;

$\mathrm{d}$ = distância de cada árvore ao centro do quadrante correspondente;

$\mathrm{d}_{\text {med }}=$ distância média entre cada árvore e o centro do quadrante correspondente;

$\mathrm{A}=\left(\mathrm{d}_{\mathrm{med}}\right)^{2}=$ área média de cada árvore na área amostrada;

Biomassa por unidade de área $=\frac{\left(\sum \mathrm{p}_{\mathrm{i}}\right)}{\sum \mathrm{A}}$

\subsubsection{Estimativa de índice de área foliar}

O IAF é a proporção da superfície total das folhas de vegetais em relação à superfície total do terreno (ART, 2001). As folhas são os órgãos fotossintetizantes por excelência, conseqüentemente há uma estreita relação entre o IAF e a atividade fotossintética na área. Através do IAF é possível estimar uma série de parâmetros como produtividade primária (TUCKER; SELLERS, 1986; VARGAS et al. 2002) e produtividade líquida (GOWER et al. 1999; LIU; KOGAN, 2002). 
Alguns tipos de vegetação, principalmente aqueles que apresentam sazonalidade marcada, apresentam a tendência de perderem as folhas na época de estresse. Fatores externos, como temperaturas extremas ou escassa disponibilidade hídrica, podem desencadear tal estresse. Uma das reações mais freqüentes nesses casos é a perda das folhas e a conseqüente diminuição dos processos metabólicos dos indivíduos. A dinâmica desses processos pode ser pesquisada através do monitoramento da evolução multi-temporal dos índices de vegetação, derivados de imagens de sensoriamento remoto (MESQUITA, 1998).

O IVDN tem sido amplamente aplicado para estimativas de IAF, que é a relação entre a superfície de folhas e a superfície de sua projeção no solo (TUCKER, 1979, SANCHEZ-AZOFEIFA et al. 2003). Outros autores têm relacionado os valores de IVDN com a quantidade de radiação fotossinteticamente ativa (GOWER et al. 1999; VARGAS et al. 2002), biomassa vegetal (BITENCOURT PEREIRA, 1986; DONG et al. 2003; SANTOS, 1988), produtividade primária e produtividade líquida (LARK; WHEELER, 2000; LIU; KOGAN, 2002).

O IAF, dentro de certos limites, relaciona-se estreitamente com alguns índices de vegetação que podem ser derivados a partir de imagens de satélites ópticos.

A comunidade científica usuária de produtos de sensoriamento remoto em áreas de vegetação tem voltado sua atenção ao conhecimento e à caracterização dessas relações (JORDAN, 1969; JACKSON; HUETE, 1991; FAASNACHT et al. 1997; HUETE et al. 1997; CARLSON; RIPLEY, 1997; HUETE et al. 1999; GUPTA; PRASAD, 2000; LARK; WHEELER, 2000; VARGAS et al. 2002; BOELMAN et al. 2003). 
Muitas vezes, é necessário caracterizar a relação existente entre o IAF e os valores de algum índice de vegetação para a área representada em uma imagem de sensoriamento remoto, orbital ou aerotransportada.

A determinação dos valores de IAF em campo pode ser realizada por meio de várias metodologias. A maioria pode ser agrupada em uma destas duas grandes classes: as que utilizam métodos destrutivos e aquelas que utilizam métodos não destrutivos. A vantagem dos métodos do primeiro grupo é a precisão dos resultados obtidos. Basicamente, tais métodos consistem em retirar todas as folhas contidas no espaço projetado acima da área de considerada e determinar a superfície de um dos lados de cada uma dessas folhas. Esse procedimento pode ser feito através da digitalização da superfície das folhas em dispositivos construídos especificamente com essa finalidade. Outro procedimento comum consiste em copiar a borda de cada uma das folhas em papel de gramatura conhecida, cortar o papel seguindo o molde das bordas e pesar as porções de papel que representem as folhas. Conhecendo-se o peso do papel, superfície total das folhas em questão pode ser calculada. Esses métodos, no entanto possuem pelo menos duas desvantagens: a de destruir o material vegetal e a de demandar muito tempo e mão de obra.

Devido aos inconvenientes mencionados, foram desenvolvidos alguns métodos que visam solucionar esses dois problemas. Um método se baseia em um modelo de transferência radiativa através de dosséis vegetais. Segundo esse modelo, a quantidade de folhas em um dossel vegetal pode ser inferida a partir da atenuação que sofre a radiação que passa através dele. O modelo que relaciona ambas variáveis exige que essa radiação, originária do sol, seja difusa (LICOR, 1992). 
O modelo parte de uma série de premissas, que devem ser consideradas na interpretação dos resultados. Uma delas é considerar que os únicos órgãos da vegetação que interceptam a radiação são as folhas. Ou seja, o modelo não considera a existência de galhos e troncos. Essa premissa torna o sistema particularmente adequado para culturas anuais e outras plantas herbáceas, nas quais a grande maioria da biomassa aérea está constituída por folhas ou material fotossintetizante. No entanto, há casos nos quais a proporção entre o material não fotossinteticamente ativo e as folhas pode conduzir a erros significativos. Além disso, o modelo pressupõe que todas as folhas presentes na árvore sejam fotossinteticamente ativas. Mesmo as folhas senescentes, nas quais a produtividade líquida é freqüentemente negativa, ou as mortas, que não realizam fotossíntese, são consideradas folhas verdes e fisiologicamente ativas.

No entanto, apesar dessas limitações, o analisador de dosséis vegetais LAI-2000 tem sido utilizado para estimar IAF em áreas florestadas (KAMPEL et al. 1997; NACKAERTS et al. 2000; SMOLANDER; STENBERG, 1996) e até no cerrado (MESQUITA, 2003; SANO et al. 2001), sendo que os resultados obtidos são considerados satisfatórios.

Para calcular o quanto a radiação que atravessa o dossel se atenua, é necessário dispor de duas medições simultâneas (ou com pouca diferença de tempo entre elas): uma medida abaixo do dossel vegetal e outra, em uma área aberta onde nada interfira no trajeto da radiação até o sensor. A quantidade de folhas presentes no dossel pode ser inferida a partir da diferença entre os dois fluxos luminosos. Esse modelo de transferência radiativa através de dosséis vegetais encontra-se implementado no analisador de dosséis vegetais LiCor LAI-2000 (LICOR, 1992). 


\section{4 - Materiais e métodos}

\section{1. Área de estudo}

O trabalho foi desenvolvido em duas fazendas do Município de Campos Novos Paulista, no Oeste do Estado de São Paulo. A área de estudo está inserida no retângulo definido pelas coordenadas $587.500 \mathrm{O}, 607.500 \mathrm{O}$ e $7.500 .000 \mathrm{~S}, 7.515 .000 \mathrm{~S}$ no fuso 22 do sistema de projeção UTM e sua posição está ilustrada esquematicamente na Figura 10.

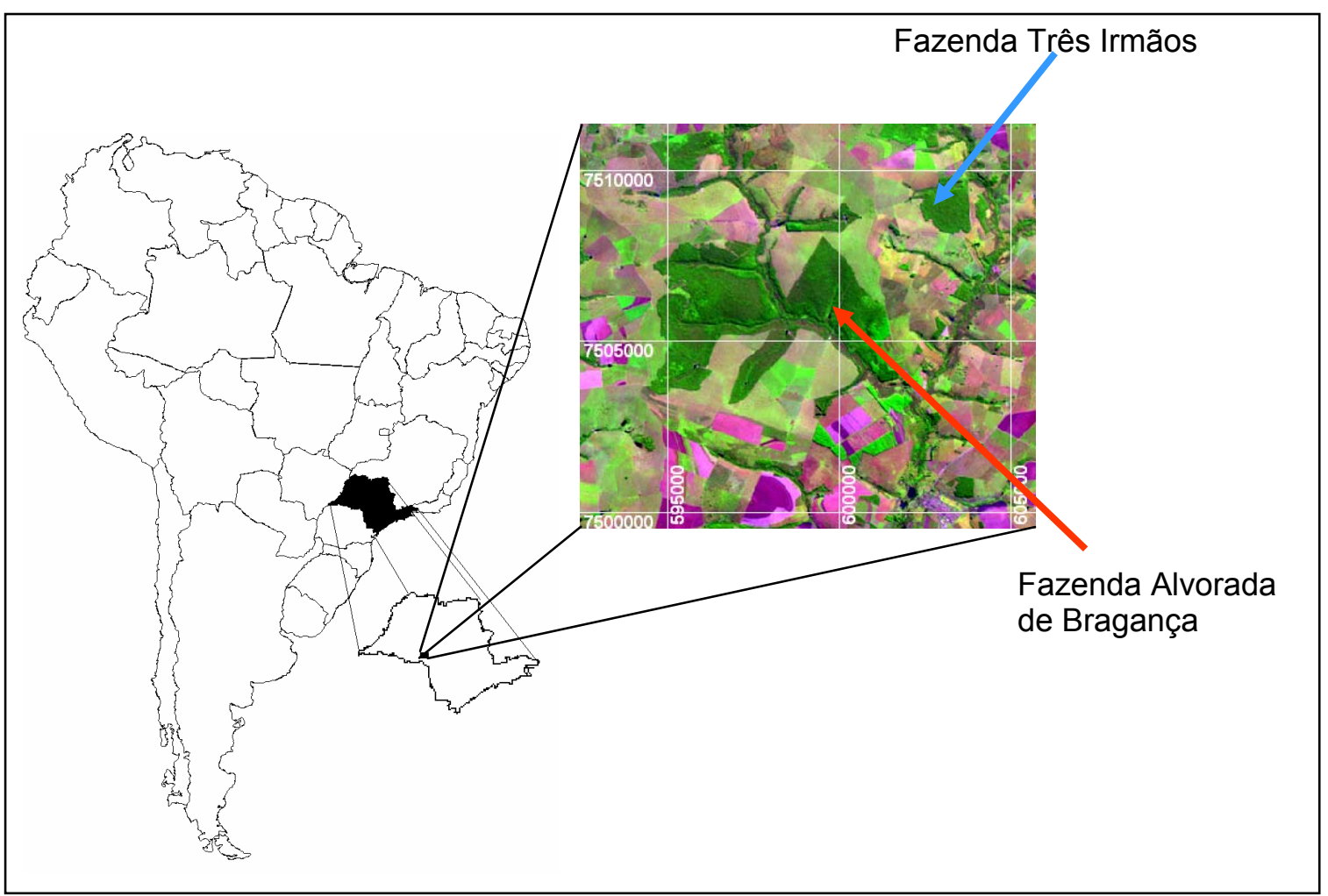

Figura 10. Localização da área de estudo com indicação da Fazenda Alvorada de Bragança e da Fazenda Três Irmãos utilizadas em este trabalho. As manchas verdeescuras indicadas pelas setas correspondem aos remanescentes de vegetação do bioma cerrado.

Kronka et al. (1993) publicaram o "Inventário Florestal do Estado de São Paulo" realizado a partir de imagens TM Landsat do período compreendido entre os anos 1987 
e 1992. A vegetação natural da área de estudo foi caracterizada como pertencente à classe cerrado. Esse inventário representa um dos mais completos levantamentos da situação dos remanescentes florestais do estado. No entanto, esse diagnóstico inclui várias informações imprecisas, principalmente no que se refere ao tipo de cobertura do solo, isto é, o tipo ou fisionomia da vegetação que consta no inventário às vezes não representa a realidade encontrada no campo. A região originariamente encontrava-se coberta por diferentes fisionomias do bioma cerrado e incluía algumas áreas de ecótono deste bioma com floresta estacional semidecidual. Atualmente, a maior parte da vegetação natural está substituída por pastagens e, em menor grau, por culturas agrícolas.

A área de estudo consiste em dois remanescentes de cerrado mapeados pelo Inventário Florestal do Estado de São Paulo (KRONKA et al. 1993).

Os remanescentes florestais aqui estudados estão incluídos na Área Prioritária A, do Projeto "The Conservation Feasibility of Cerrado Remnants in São Paulo State", inserido no Programa BIOTA/FAPESP.

A Figura 11 corresponde a uma imagem ETM+ da região de estudo. Os limites dos municípios estão representados por linhas brancas e os dos polígonos mapeados pelo Inventário Florestal do Estado de São Paulo (KRONKA et al. 1993), aparecem em linhas negras. As áreas verde-escuras correspondem à vegetação natural, as áreas verdeclaras correspondem a culturas anuais e as áreas de cor rosa e magenta correspondem a solo exposto ou aos primeiros estágios de desenvolvimento de vegetação. 


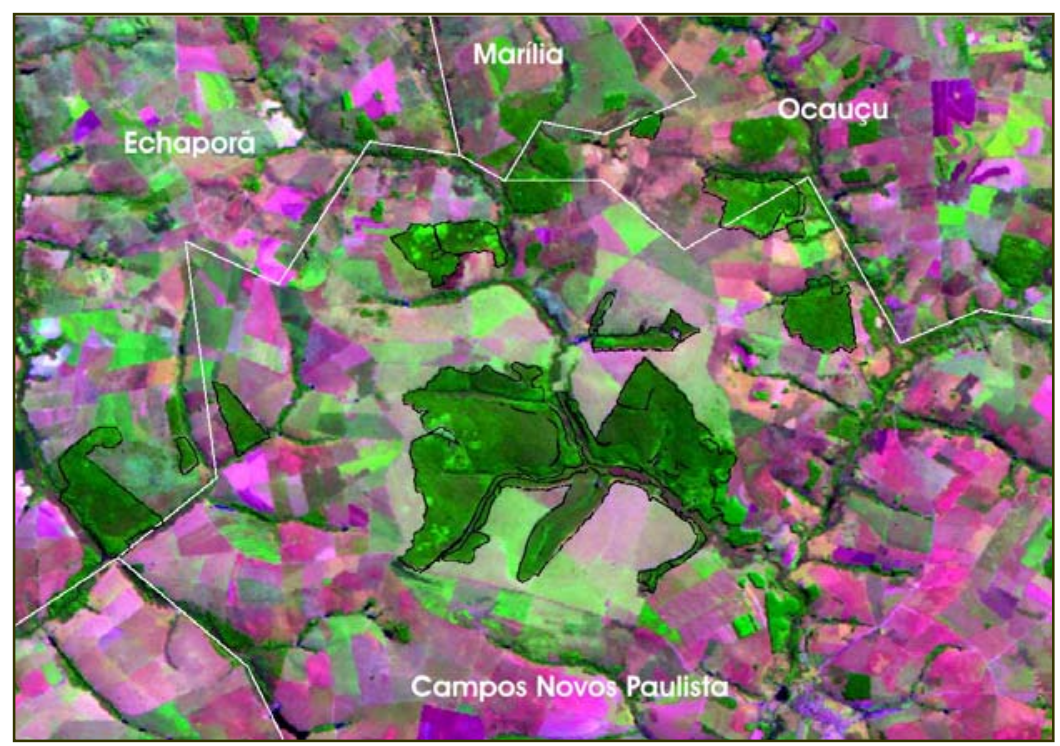

Figura 11. Imagem ETM+ da região de estudo com os limites municipais.

A Fazenda Alvorada de Bragança possui um grande remanescente contínuo de cerrado e cerradão de forma irregular. Esta última característica ocasiona que o efeito de borda seja acentuado na área. O fragmento encontra-se rodeado por pastagem, o qual é destinado à criação de gado. A Figura 12 mostra o extremo Noroeste deste remanescente, cuja área total é de 1484,6 ha.. Na figura podem ser observadas as diferentes coberturas do solo encontradas na área de estudo. O remanescente de cerradão presente nesta fazenda foi selecionado devido ao bom estado de conservação observado nas visitas a campo, realizadas por pesquisadores do Projeto "The Conservation Feasibility of Cerrado Remnants in São Paulo State", inserido no Programa BIOTA/FAPESP. 


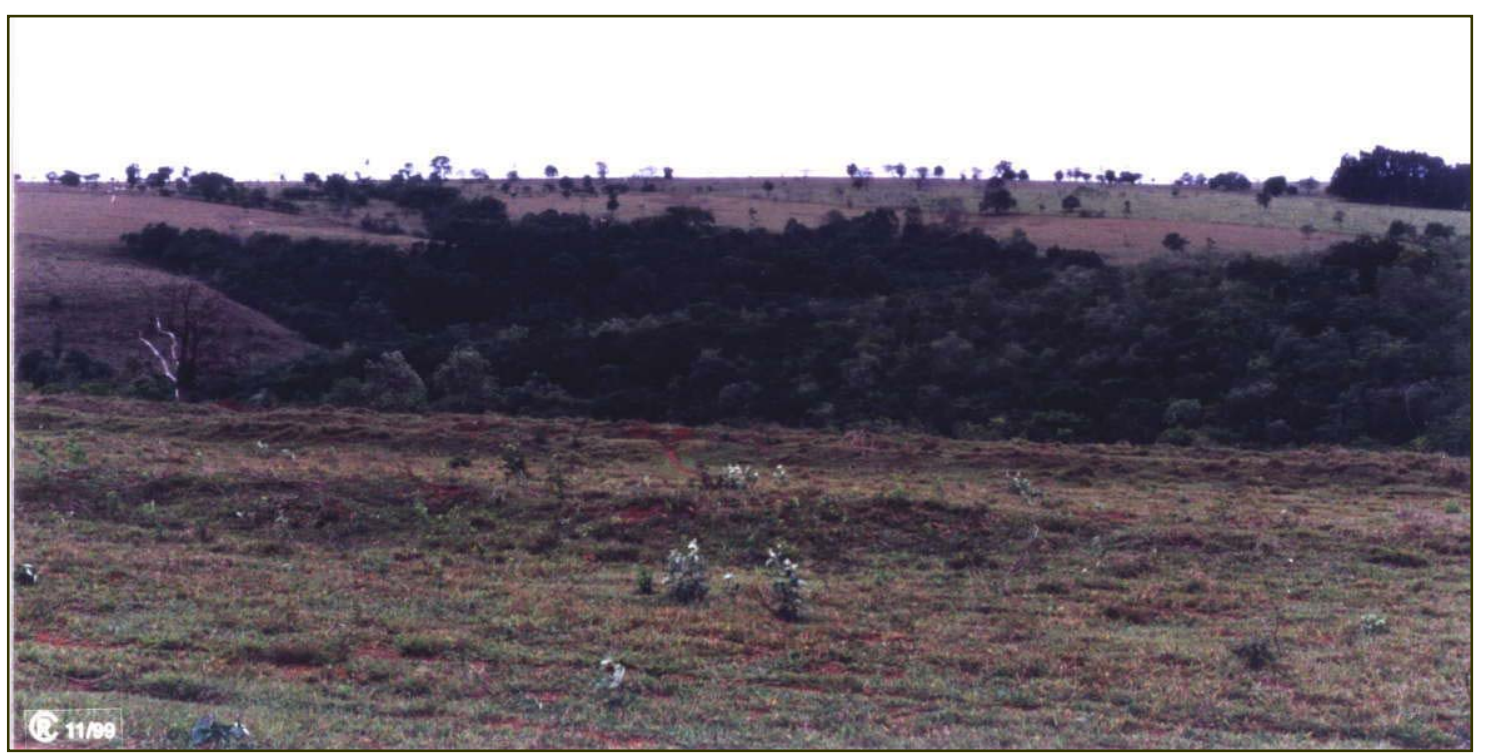

Figura 12. Aspecto da área localizada no Noroeste do remanescente de cerrado da Fazenda Alvorada de Bragança. No primeiro plano pode se observar uma área coberta por pastagem; no centro da fotografia pode-se observar cerradão e no extremo superior direito, ecótono de cerradão com floresta estacional semi-decidual.

Nos últimos anos, diferentes funcionários administraram a fazenda, portanto não foi possível obter informações detalhadas sobre o histórico de uso e ocupação das terras. Devido à ausência de dados, buscaram-se outras fontes de informações. A carta topográfica Campos Novos Paulista (IBGE, 1975) mostra que a maior parte da área correspondente à fazenda aparece descrita como coberta por pastagem. A única exceção está constituída por uma estreita faixa localizada ao longo de uma drenagem que se distribui aproximadamente de Norte a Sul entre os pontos de coordenadas $7507000 \mathrm{~S}$, $597500 \mathrm{O}$ e 7505500 S, 598000 O. A vegetação desta faixa está descrita na legenda da carta como sendo "mata, cerrado, macega, floresta ou caatinga". Embora estas descrições sejam excessivamente amplas, pode se inferir a partir delas que a vegetação florestal mais antiga da área esteja localizada precisamente dentro dessa faixa. Também parece lógico assumir que a regeneração do cerrado stricto sensu e do cerradão nas áreas vizinhas tenha ocorrido, pelo menos em parte, a partir de propágulos provenientes 
desta faixa. Por estes motivos, assumiu-se que era altamente provável que a maior densidade de biomassa florestal estivesse localizada ali.

Posteriormente foi incorporada a este estudo uma outra área de cerradão, localizada na Fazenda Três Irmãos, ao Nordeste da Fazenda Alvorada de Bragança. Essa área, incorporada após o início da pesquisa, inclui um remanescente de cerradão de menores dimensões que o anterior, porém com um melhor estado de conservação daquele presente na Fazenda Alvorada de Bragança. A forma deste remanescente é aproximadamente circular, o que, junto ao fato de encontrar-se protegido por uma cerca de arame farpado, diminui o efeito de borda, colaborando assim na preservação do fragmento. A área do remanescente presente na Fazenda Três Irmãos é de 178 ha.

Para esta pesquisa, foram utilizadas algumas áreas que atualmente estão ocupadas por diferentes fisionomias do bioma cerrado, inseridas no retângulo já mencionado. A superfície total dessas áreas é de 1662,5 ha.

O clima da região de estudo é do tipo AWi, segundo Köppen (1948), com chuvas tropicais concentradas durante a estação estival, enquanto que o inverno está caracterizado como estação seca. A média das precipitações anuais é 1390 mm (SÃO PAULO, 2003).

Os solos predominantes na região são leves, com predomínio de areia, baixa capacidade de troca de cátions e baixa saturação de bases. A adição de material calcáreo é uma prática comumente adaptada em toda a região e se repete a cada três anos, com o objeto de aumentar a saturação de bases e diminuir a acidez. Naturalmente esses solos possuem baixa quantidade de matéria orgânica e essa tendência se acentua com a prática da queima. Essa prática de manejo visa eliminar espécies indesejáveis para a 
exploração comercial das terras e para incentivar a rebrota das pastagens após o fim do período seco.

O memorial do Mapa Pedológico do Estado de São Paulo descreve os solos da região como Podzólicos Vermelho Amarelos (PVA), eutróficos e distróficos. Incluem argissolos vermelhos de textura média e arenosa média. O relevo geralmente é plano a suavemente ondulado (OLIVEIRA et al. 1999).

As atividades que predominam no setor agropecuário da região são a criação de gado bovino e, em menor escala, o plantio de eucalipto, laranja, mandioca, cana de açúcar e milho.

\subsection{Métodos de campo}

\subsubsection{Escolha das áreas amostrais}

$\mathrm{Na}$ primeira parte do projeto foi feito um reconhecimento da região e foram selecionadas as áreas onde seriam realizadas as amostragens. Para tanto, foi feito um levantamento preliminar da vegetação natural dos remanescentes mapeados por Kronka et al. (1993). Estes remanescentes foram atualizados com o auxílio da imagem de 20 de maio de 1999. Esta imagem, juntamente com outra de 22 de julho de 1993, foram úteis na fase de planejamento e de preparação dos trabalhos de campo. A partir da imagem IVDN de 1999 foi possível separar os grandes grupos de cobertura do solo: área agrícola e pastagem, cerrado, cerradão e ecótono de cerradão com floresta estacional semidecídua. Constatou-se no campo que as áreas que apresentam menor densidade de vegetação coincidem com os intervalos de IVDN mais baixos e as áreas com vegetação mais densa coincidem com os intervalos de IVDN mais altos, como era esperado.

O resultado da classificação da imagem IVDN gerou um zoneamento preliminar mostrado na Figura 13 que serviu de base para o planejamento e posterior realização de 
um levantamento florístico expedito (DURIGAN et al. 2003). O levantamento expedito baseou-se no método elaborado por Ratter et al. (2000a,b) e Ratter et al. (2003) e foi realizado em setembro e outubro de 1999. Esse levantamento também foi georreferenciado com GPS e seus resultados encontram-se disponíveis on line no Sistema de Informação Ambiental do Projeto Biota/FAPESP (DURIGAN, 2000) e no Anexo 2 do presente trabalho.

Os fragmentos estudados no presente trabalho são os 1.x e 17 e duas áreas externas aos fragmentos, mas próximas ao 17.

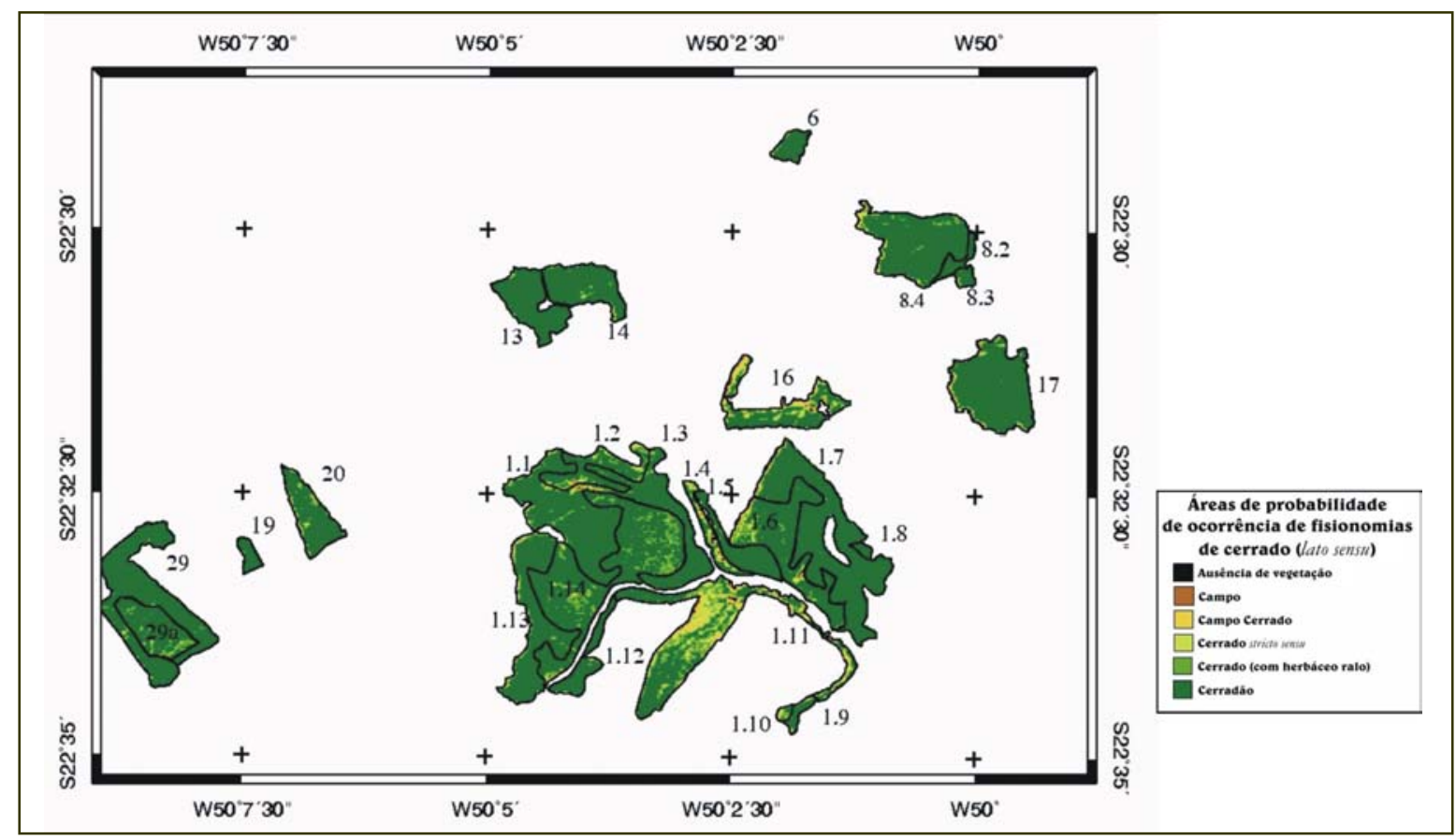

Figura 13. Zoneamento da área de estudo elaborado a partir de imagem IVDN onde se mostram as áreas de probabilidade de ocorrência de fisionomias de cerrado.

A localização das áreas para a posterior coleta de dados biofísicos foi selecionada com base nas informações extraídas da imagem IVDN de 1999 e do levantamento florístico expedito (DURIGAN et al. 2003; RATTER et al. 2000a,b e RATTER et al. 2003). 
Também foram consideradas outras informações referentes à história de uso do solo nas fazendas estudadas. Com base nelas, também foi incluída na amostragem a faixa de vegetação natural que se distribui aproximadamente de Norte a Sul no centro do fragmento da Fazenda Alvorada de Bragança, mencionada anteriormente. Esta área foi incluída por considerar-se que é onde se localizam os remanescentes mais antigos de vegetação natural dentro da área.

Duas estratégias distintas foram utilizadas para avaliar a vegetação no presente trabalho. As áreas com vegetação predominantemente aberta foram avaliadas com um dispositivo analisador de dosséis vegetais. As áreas com predomínio de fisionomias florestais tiveram sua quantidade de vegetação lenhosa estimada mediante o uso de equações alométricas.

Foram selecionadas nove áreas com vegetação predominantemente aberta (1A a 9A) e outras dez áreas diferentes com predomínio de vegetação lenhosa densa (1B a 10B). Ambos levantamentos consideraram áreas de diferentes tamanhos. A Tabela 4 representa as dimensões e as coordenadas geográficas do ponto aproximadamente central de cada uma das nove áreas com vegetação aberta.

A área $1 \mathrm{~A}$ corresponde a uma mata ciliar, localizada à beira de um córrego que atravessa a Fazenda Alvorada de Bragança. A vegetação nessa área é mais densa do que nas outras regiões amostradas nesta parte do trabalho, pois provavelmente ela nunca se encontre submetida a estresse hídrico. Um possível aporte de sedimentos pelo curso de água também pode ser a causa de que a vegetação aqui seja tão densa. A mata ciliar que foi preservada nessa área é estreita, limitando-se à encosta da drenagem. 
TABELA 4. Dimensões e coordenadas das áreas 1A a 9A amostradas.

\begin{tabular}{cccc}
\hline Área & Número de pixels & Superfície $\left(\mathrm{m}^{2}\right)$ & Coordenadas UTM 22S \\
\hline 1A & 17 & 15300 & 5978367508560 \\
2A & 42 & 37800 & 5955247506326 \\
3A & 13 & 11700 & 5970707507630 \\
4A & 10 & 9000 & 5961897507706 \\
5A & 13 & 11700 & 5968007507690 \\
$6 \mathrm{~A}$ & 32 & 28800 & 5966267506712 \\
7A & 30 & 27000 & 5988487506476 \\
$8 \mathrm{~A}$ & 11 & 9900 & 5955407506500 \\
9A & 41 & 36900 & 5986687506499 \\
\hline
\end{tabular}

A área $2 \mathrm{~A}$ corresponde a um tipo de vegetação transicional do ponto de vista da quantidade de biomassa. A Oeste, o solo está coberto por pastagem implantada, apresentando algumas árvores de grande porte distanciadas entre si. Provavelmente, essas árvores são remanescentes de uma fisionomia tipo cerradão que cobria a área no passado. Atualmente, o cerrado que cobre a área amostrada é baixo e aberto. Próxima a essa área há uma região coberta exclusivamente por Pteridium spp. Ao redor da área amostrada, o solo está coberto por cerradão. Estas duas situações podem ser observadas na Figura 14. 


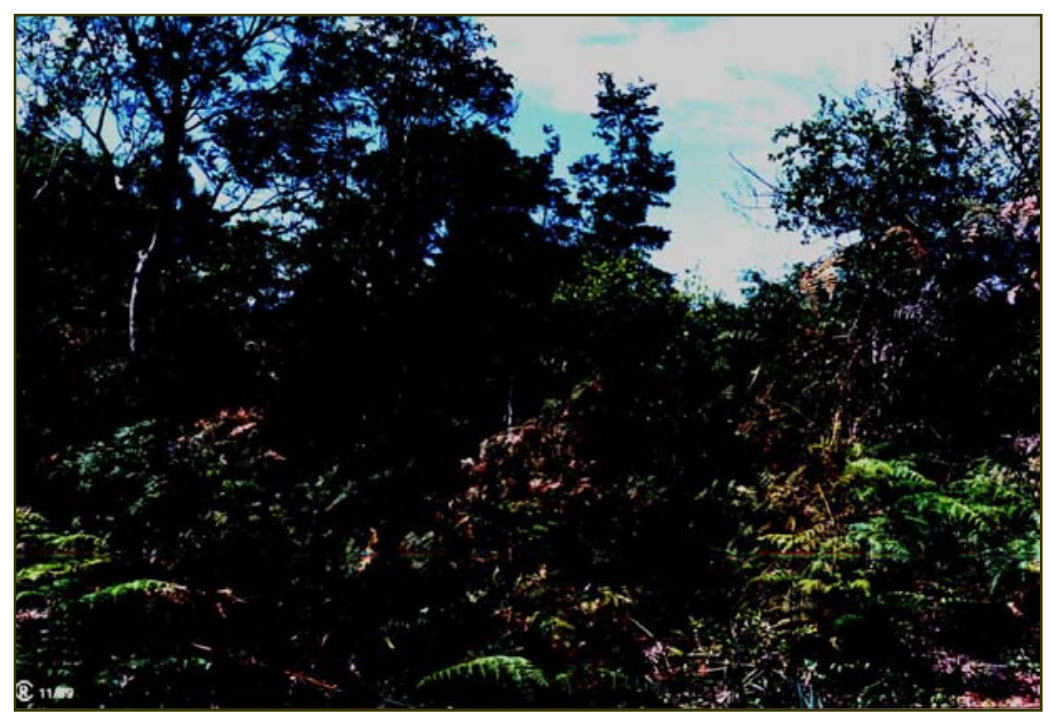

Figura 14. A área 2A encontra-se coberta por cerrado stricto sensu e rodeada por Pteridium spp. e cerradão, como representado na fotografia.

A área 3A localiza-se próxima a um depósito de lixo dentro da Fazenda Alvorada de Bragança. Ela foi selecionada devido à escassa cobertura florestal presente, o que a torna adequada ao monitoramento através de imagens índice de vegetação. A escolha do lugar como depósito de lixo provavelmente foi devida a que a vegetação no lugar tenha sido originalmente escassa. Isto pode ser devido a alguma característica do solo. A vegetação que rodeia o depósito de lixo é esparsa. Neste local, encontrou-se maior número de plantas com adaptações xeromórficas do que nas outras áreas amostradas. A vegetação se transforma gradativamente em cerrado stricto sensu à medida que se afasta do depósito de lixo.

A área 4A está próxima da borda Noroeste do fragmento. A vegetação que a cobre corresponde a um cerrado fechado, relativamente denso, alto e com abundantes folhas verdes na época dos trabalhos de campo.

A área 5A encontra-se ocupada por cerrado stricto sensu baixo e aberto, mais ralo que o encontrado na área 4A. Nesse caso, ao contrário dos outros pontos cobertos por 
vegetação com estas características, o solo encontrava-se coberto por serapilheira, sem evidências de ação do fogo em um passado recente. A maioria das árvores estava desprovida de folhas, havendo abundância de ciperáceas no estrato herbáceo.

A área 6A é a mais central dentro do fragmento e devido a isto, provavelmente é a menos afetada pelo efeito de borda. O tipo de vegetação presente no local é cerrado stricto sensu denso.

A área 7A encontra-se coberta por cerrado stricto sensu denso e baixo, de aproximadamente 1,5 metro de altura.

A área 8A está ocupada por uma fisionomia de cerrado stricto sensu baixo. O estrato herbáceo encontra-se dominado por ciperáceas e há muitas bromélias de solo. Isso permite inferir que o solo apresenta algum tipo de mudança, quando comparado ao da área anterior. Essas diferenças no substrato poderiam ocasionar diferenças inclusive na vegetação arbórea. Por essa razão, esta área também foi selecionada para amostragem.

A área 9A encontra-se coberta por cerrado stricto sensu, com predomínio de árvores de aproximadamente 1,5 metro de altura. Ela está localizada próxima de uma borda de contato cerrado-pastagem aproximadamente no centroleste do fragmento. Não foram encontradas ciperáceas no estrato herbáceo, estando este último constituído principalmente por gramíneas e dicotiledôneas. Não foi feito levantamento florístico do estrato herbáceo.

A Tabela 5 indica as dimensões de cada uma das dez áreas com vegetação densa amostradas e as coordenadas geográficas aproximadas do ponto central de cada uma dessas áreas. 
TABELA 5. Dimensões e coordenadas das áreas 1B a 10B amostradas.

\begin{tabular}{cccc}
\hline Área & Número de pixels & Superfície $\left(\mathrm{m}^{2}\right)$ & Coordenadas UTM 22S \\
\hline 1B & 368 & 119232 & 06004347506980 \\
2B & 199 & 64476 & 06010247506601 \\
3B & 50 & 16200 & 05955007506500 \\
4B & 26 & 8424 & 05998027505514 \\
5B & 16 & 5184 & 05956007506100 \\
6B & 16 & 5184 & 06031847509365 \\
7B & 46 & 14904 & 05977507505555 \\
8B & 85 & 27540 & 06033047508911 \\
9B & 16 & 5184 & 05974657506950 \\
10B & 35 & 11340 & 05977537506443 \\
\hline
\end{tabular}

A área 1B estava antigamente ocupada por cerradão. Nela, a vegetação florestal foi quase totalmente retirada para a implantação de pastagem. O objetivo do proprietário foi destinar essa área para a criação de gado. Portanto, a maioria das árvores foi cortada e a regeneração tem sido evitada continuamente. Nesta área, foram mantidos alguns indivíduos de grande porte com a finalidade de fornecer sombra para o gado, conforme pode ser observado na Figura 15. Essas árvores, no entanto, encontram-se muito esparsas. $\mathrm{O}$ grande distanciamento entre as árvores, com a conseqüente diminuição da competição por luz, água e nutrientes, pode ter contribuído para o aumento do tamanho dos indivíduos. 


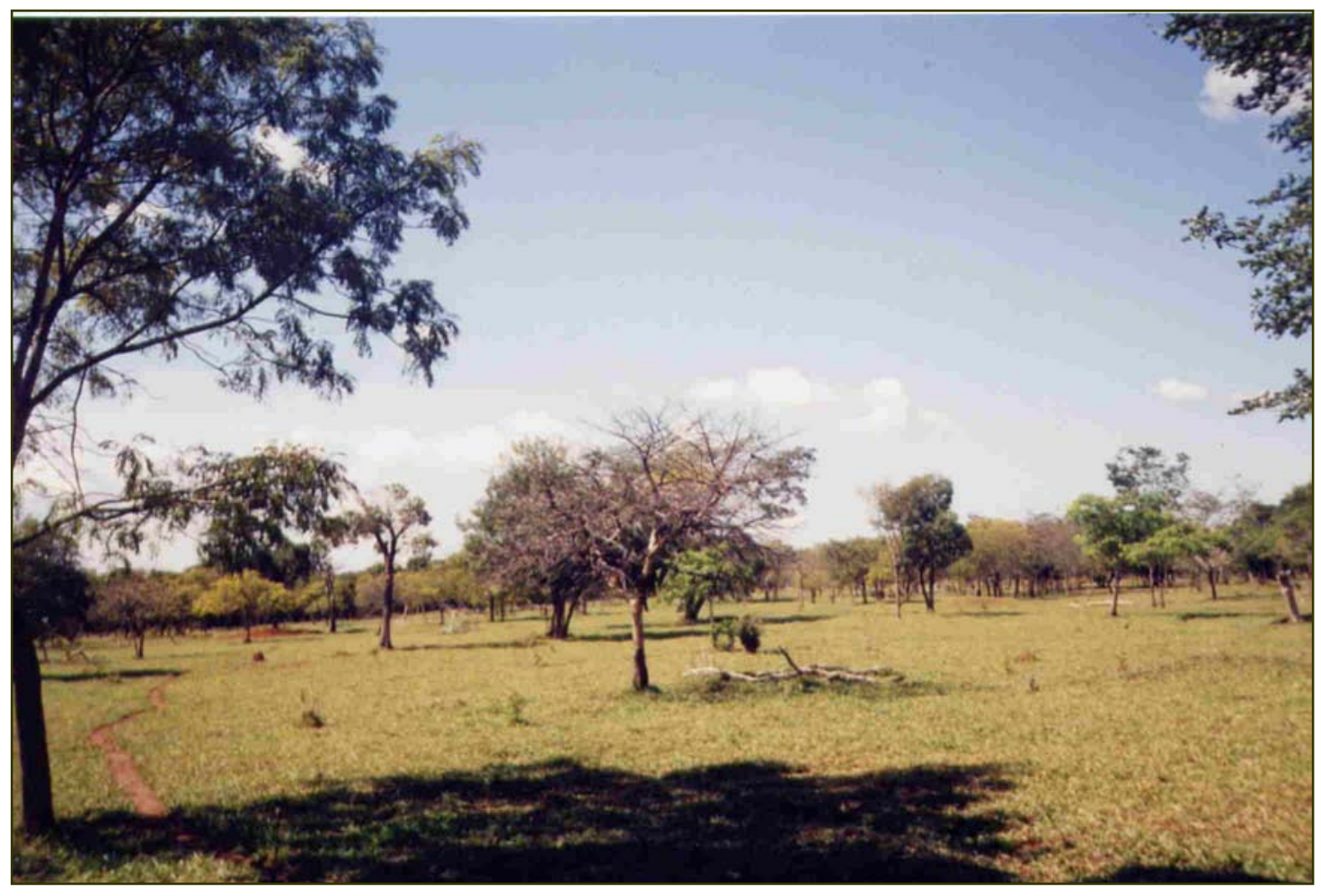

Figura 15. Aspecto da vegetação na área 1B.

A área 2B corresponde a uma região localizada ao Sul da área 1B. O aspecto visual em campo leva a supor que é possível que as duas áreas originalmente tivessem coberturas vegetais similares. A vegetação florestal nesta área também foi parcialmente retirada, com o mesmo objetivo de implantar pastagem e dedicar a área para a criação de gado. No entanto, foram preservados mais indivíduos arbóreos que na área 1B para fornecer sombra.

A área 3B encontra-se coberta por cerrado stricto sensu aberto. As árvores aqui apresentam menores dimensões, porém são mais numerosas do que nas áreas anteriores. A cobertura vegetal da área 4B corresponde a um ecótono entre cerradão e florestaestacional-semidecidual, de acordo com o levantamento florístico realizado por Durigan (1999). Este tipo de vegetação permitiria esperar valores de biomassa vegetal significativamente maiores aos que se observam nas áreas cobertas tanto pelo cerrado 
quanto pelo cerradão (BATALHA et al. 2001). Há aproximadamente 20 anos, toda a vegetação arbórea presente no local foi retirada, sendo que apresenta uma cobertura florestal atual em processo de regeneração. Há predomínio de árvores finas. Entre as árvores grossas é comum a presença de rebrote desde a parte inferior do caule, como pode ser observado na Figura 16, pois foi a porção que permaneceu no terreno após a retirada do fuste, que é a porção com valor comercial. Das 80 árvores amostradas nesta área, 17 (21,25\%) apresentaram este fenômeno de rebrote múltiplo axilar (Tabela 6). Esta área encontra-se comunicada com outras destinadas à pastagem, por isso o gado a invade continuamente, dificultando assim a regeneração da vegetação florestal. Provavelmente a vegetação nessa área está longe de ter atingido o clímax determinado pelo solo. Supõe-se que a quantidade de biomassa por unidade de área nesse local aumente com o decorrer do tempo. Essa seria a expectativa, caso nenhum outro fator (como a ação do gado) impedisse o avanço do processo sucessional. A área apresenta declive, que acaba em uma drenagem com campo úmido. 


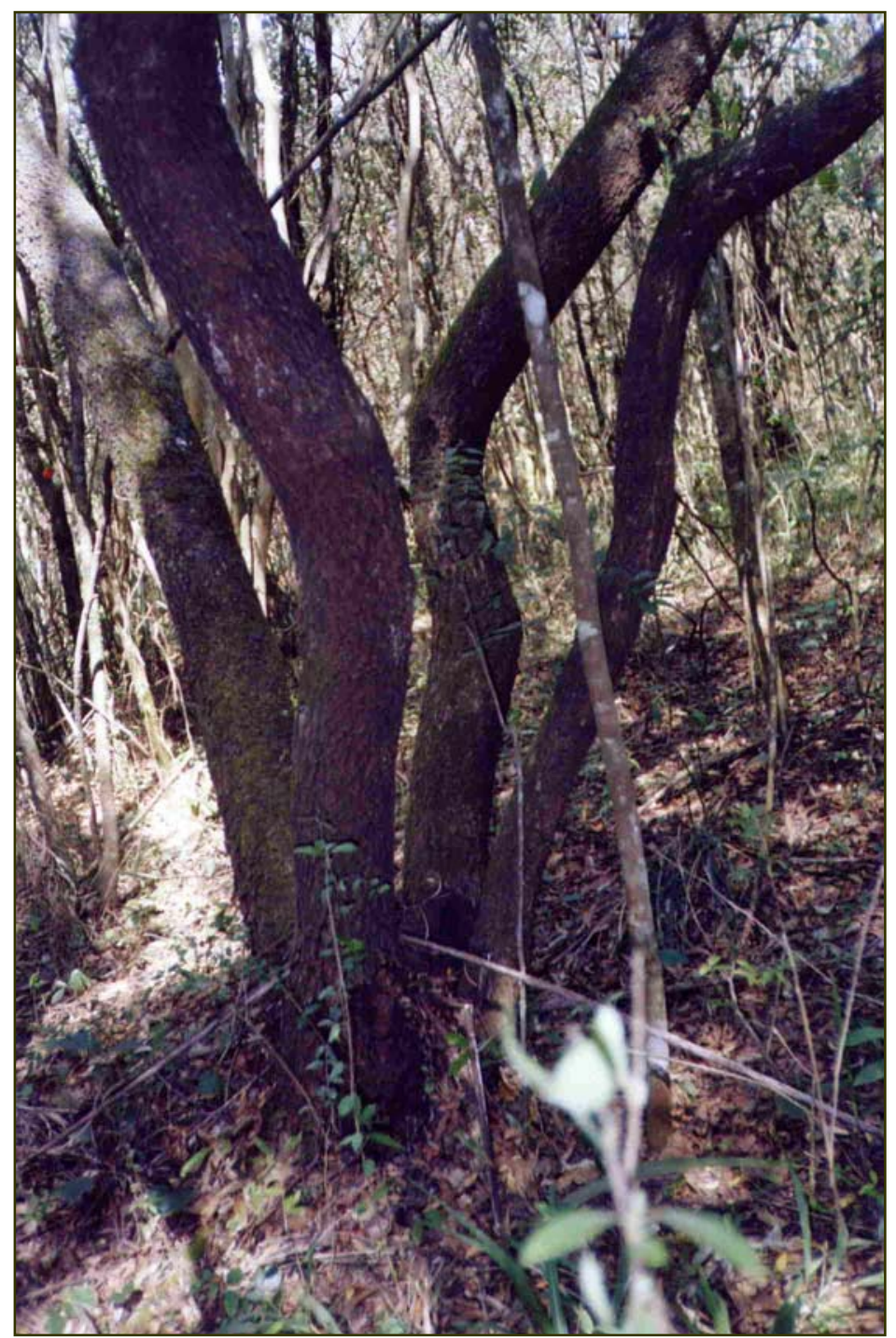

Figura 16. Aspecto da vegetação da área 4B, onde se pode observar uma árvore com rebrote desde a base do caule.

$\mathrm{A}$ área $5 \mathrm{~B}$ encontra-se muito afastada das bordas de contato entre a vegetação natural e as pastagens implantadas. Está coberta por cerradão e apresenta abundante acumulação de serapilheira no solo (Figura 17), contrariamente às outras áreas amostradas. Este é um indício de que o fogo provavelmente não penetra nesta área, e se o faz, esse evento não se repete freqüentemente. As árvores encontram-se a uma distância média similar às árvores da última área descrita. 


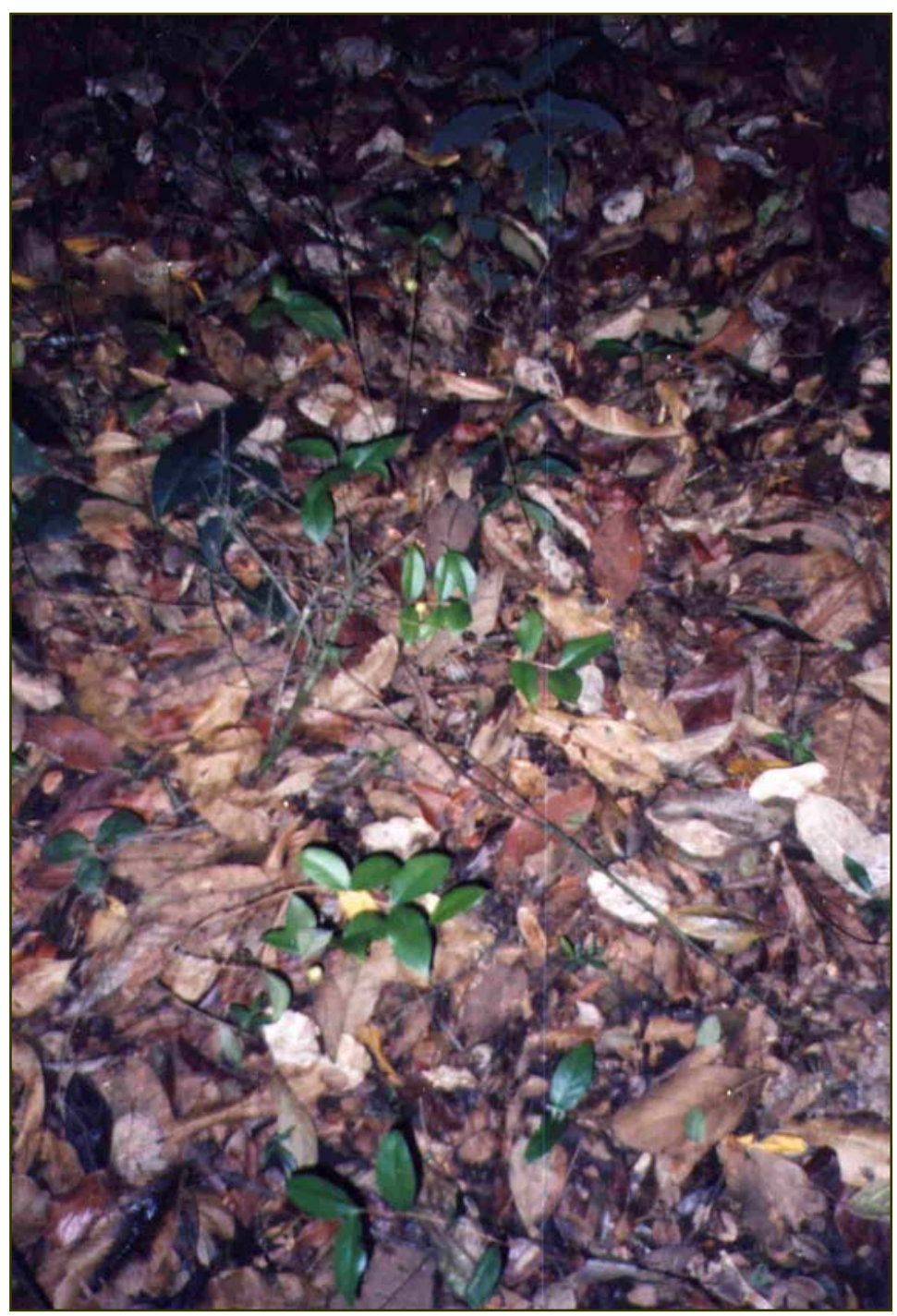

Figura 17. Solo da área 5B onde pode ser observado o acúmulo de serapilheira.

Todas as áreas descritas até aqui estão localizadas dentro da Fazenda Alvorada de Bragança. As áreas 6B e 8B estão em um fragmento geograficamente separado das áreas anteriores. Esse é o único fragmento amostrado nesse trabalho que se encontra dentro da Fazenda Três Irmãos. A vegetação arbórea que cobre esse fragmento foi submetida a corte raso há aproximadamente 30 anos, mas desde então tem sido protegida com cercas de arame farpado, que impedem a entrada de gado, conforme pode ser observado na Figura 18. Por este motivo, o avanço da regeneração da vegetação natural é significativo e o fragmento está coberto por cerradão em bom estado de 
conservação, determinando uma fisionomia tipicamente florestal. Dentro do fragmento foram selecionadas duas áreas amostrais relativamente homogêneas.

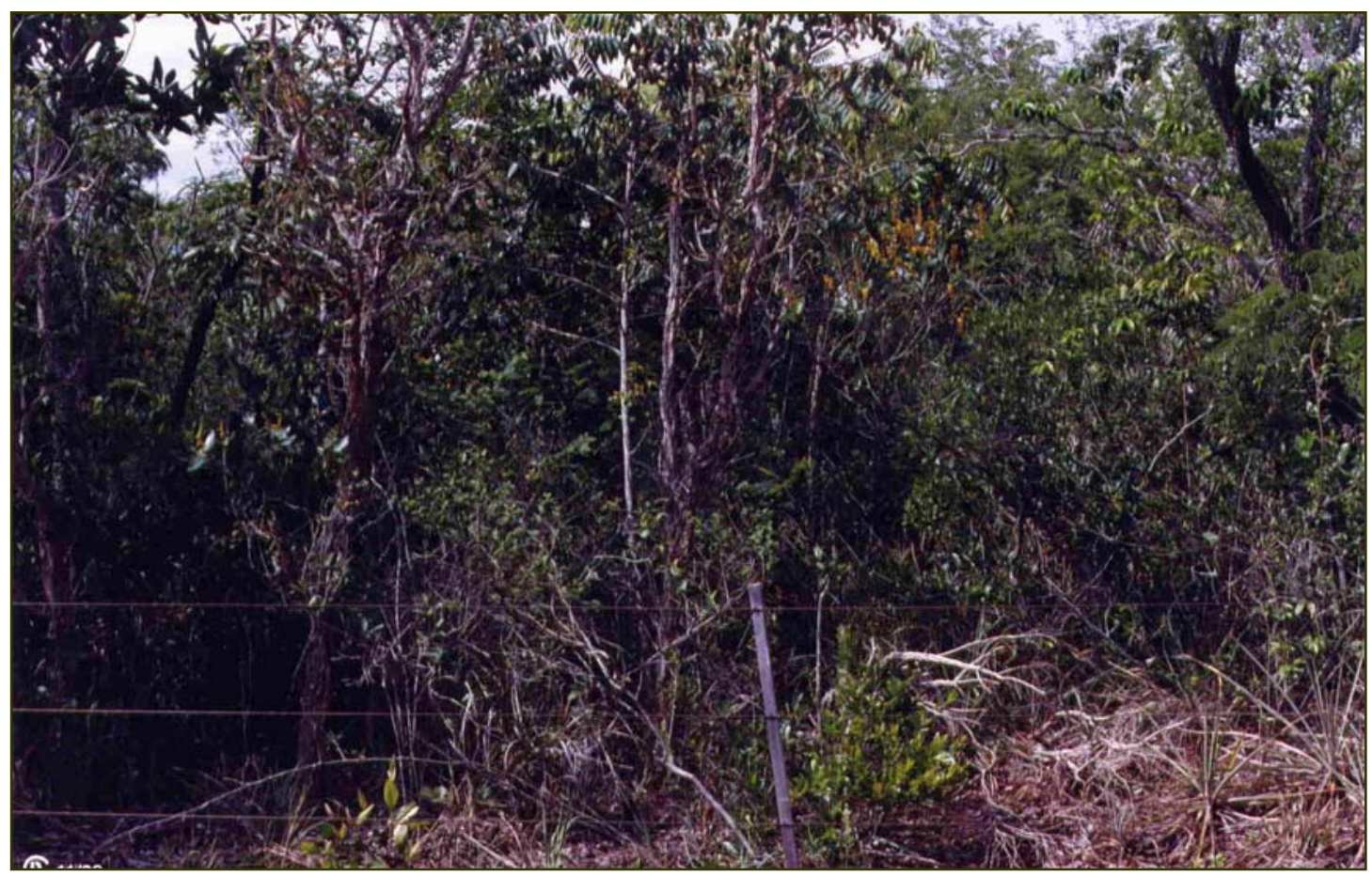

Figura 18. Aspecto da vegetação na área 6B. Em primeiro plano, na parte inferior da foto, observa-se a cerca que impede o acesso do gado à área coberta por cerradão.

A área 6B é a mais próxima da borda. Ela se encontra na parte Norte do fragmento. Esta área apresenta maior quantidade de arbustos que a área localizada no interior do remanescente.

$\mathrm{A}$ área $8 \mathrm{~B}$, que está dentro do mesmo fragmento de cerradão, encontra-se mais afastada do limite da fisionomia florestal com o pasto e, portanto, provavelmente é menos influenciada pelo efeito de borda. O ambiente no interior desta área do fragmento é mais escuro e úmido que no anterior. 
TABELA 6. Percentagem de indivíduos com rebrote múltiplo axilar desde a base em cada área amostrada.

\begin{tabular}{cc}
\hline Área & $\begin{array}{c}\text { Percentagem de indivíduos } \\
\text { com rebrote múltiplo axilar } \\
\text { desde a base }\end{array}$ \\
\hline 1B & 37,5 \\
2B & 31,25 \\
3B & 27,5 \\
4B & 21,25 \\
5B & 12,5 \\
6B & 16,25 \\
7B & 21,25 \\
8B & 15 \\
9B & 17,5 \\
10B & 37,5 \\
\hline
\end{tabular}

Poucas informações estão disponíveis sobre o histórico de uso do solo nas fazendas estudadas. Na carta topográfica Campos Novos Paulista (IBGE, 1975), toda a área da Fazenda Alvorada de Bragança, que inclui todas as áreas amostradas com exceção das duas mencionadas por último, aparece descrita como coberta por pastagem. A única exceção está constituída por uma faixa localizada ao longo de uma drenagem, distribuise aproximadamente de Norte a Sul. Na legenda da carta, esta área está descrita como "mata, cerrado, macega, floresta ou caatinga". Embora esta descrição seja excessivamente ampla e geral, pode-se inferir que a vegetação florestal mais antiga da área esteja localizada exatamente dentro dessa faixa. Também parece lógico admitir que a regeneração do cerrado stricto sensu e do cerradão nas áreas vizinhas tenha sido feita, pelo menos em parte, a partir de propágulos provenientes da vegetação presente nesta faixa. Por estes motivos, foram definidas três áreas de amostragem na região (áreas 7B, 9B e 10B). A primeira dessas áreas, identificada como área 7B, está em uma encosta 
com alta declividade, à beira da drenagem mencionada. Esta é a área localizada mais ao Sul das três à beira da drenagem. O solo encontra-se coberto por vegetação que conforma uma fisionomia do tipo cerradão, com algumas árvores emergentes. Há evidências de presença de fogo no passado, identificado por restos de carvão na cortiça de alguns indivíduos arbóreos. $\mathrm{O}$ ambiente no sub-bosque é úmido e existem touceiras de bambu e numerosas bromélias de chão.

A área 9B é a que está localizada mais ao Norte dentro da faixa mencionada que contorna a drenagem e apresenta características similares à anterior.

A área 10B é a terceira e última área amostrada dentro da faixa de vegetação à beira da drenagem. Encontra-se localizada entre as áreas 9B e 7B e apresenta grandes árvores e o solo coberto por serapilheira. O ambiente é úmido e umbrófilo.

É possível que o fato de estas três últimas áreas estarem localizadas em uma área próxima a um curso de água, e devido a isso não submetida a déficit hídrico em nenhum período do ano, seja responsável pelo desenvolvimento da vegetação florestal. Além disso, deve-se ter em vista que, provavelmente, esta seja a área com vegetação nativa mais antiga dentro da região estudada.

\subsubsection{Estimativa do IAF}

O dispositivo analisador de dosséis vegetais LAI-2000 (LICOR, 1992), foi utilizado no campo para estimar o IAF nas áreas onde predomina a vegetação aberta dentro da área de estudo. O equipamento consta de dois conjuntos de coleta de dados, cada um com uma unidade de armazenamento e um programa que é utilizado para comunicação e processamento. 
Os valores numéricos utilizados durante a pesquisa foram armazenados e processados nos softwares Excel, Statistica 5.1 (STATSOFT, 1996).

A seguir, foi feita a determinação dos valores de IAF, nas áreas mais abertas, e de biomassa lenhosa aérea, nas áreas com vegetação densa. Posteriormente foram realizados os processamentos das imagens, tanto as de radar quanto as ETM+ Landsat7. Posteriormente foram comparados os valores extraídos das imagens com os coletados no campo a fim de buscar relações entre eles.

As determinações de IAF no campo foram feitas em duas datas: nas semanas de 6 a 10 de maio e de 2 a 6 de setembro de 2002. A imagem utilizada nesta etapa do trabalho é de 5 de junho do mesmo ano, ou seja, em uma data entre os dois conjuntos de medições. Em condições ideais, a data da imagem e a data de amostragem no campo deveriam coincidir. As imagens que fornecem maior quantidade de informações da superfície da terra são aquelas livres de nuvens, o que ocorre com mais freqüência no período seco, quando a vegetação já perdeu muitas folhas. Isto apresenta um conflito de interesses, pois a condição mais adequada para determinar o IAF no campo com o LAI-2000 é quando a radiação solar é difusa, o que ocorre justamente quando o céu se encontra coberto de nuvens. Também seria possível trabalhar no início da manhã ou no final da tarde, quando a iluminação é difusa. A desvantagem é que essas condições se mantêm por pouco tempo. Apesar disso, este trabalho foi realizado nesses horários.

Devido às diferentes dimensões das áreas consideradas, o esforço amostral foi diferente em cada uma delas.

Pela metodologia empregada, o operador deveria caminhar, em linha reta, de costas para o sol, e realizar uma leitura a cada cinco passos. Em áreas muito grandes, foram 
coletados valores em várias linhas paralelas para obter registros representativos de toda a variação da vegetação arbórea presente no local.

O sensor base que permanecia fora do dossel foi configurado para registrar os valores a cada 15 segundos.

Em todas as ocasiões, foram utilizadas máscaras que ocultavam parte da lente do sensor, a fim de eliminar a interferência do corpo do operador nas leituras. Em algumas parcelas, a máscara usada foi de $270^{\circ}$ (abertura de $90^{\circ}$ ) e, em outras, de $315^{\circ}$ (abertura de $45^{\circ}$ ). Foram utilizados sempre os mesmos tipos de máscaras no sensor que estava localizado na área aberta, o que era utilizado para efetuar as medições da vegetação arbustivo-arbórea.

\subsubsection{Estimativa da biomassa lenhosa aérea em áreas de fisionomias florestais}

$\mathrm{Na}$ parte do trabalho que exigiu a estimativa dos valores de biomassa lenhosa aérea no campo foi utilizado o método de quadrantes centrado em uma árvore (MUELLERDOMBOIS; ELLENBERG, 1974). Este método permitiu sistematizar a seleção das árvores a partir das quais se mediram as distâncias ao centro da árvore de referência bem como também se registraram os dados biofísicos a necessários para o calculo dos valores de biomassa.

As espécies arbóreas do cerrado têm a característica de possuírem troncos geralmente tortos e ramificados desde a base (RIZZINI, 1979), o que levou à medição do DB ao invés do DAP. Este último parâmetro é mais utilizado em fisionomias tipicamente florestais, onde as árvores apresentam um único fuste até 1,30 metro de altura.

Com base nos levantamentos descritos anteriormente, foram definidas 10 unidades

amostrais (Tabela 5). Em cada uma destas unidades realizou-se a amostragem de 20 
pontos quadrante, o que determinou o registro das variáveis biofísicas de 80 árvores em cada área e um total de 800 árvores nesta etapa do trabalho. Definiu-se como critério de inclusão o valor limiar de $15 \mathrm{~cm}$ de perímetro na base (PB), posteriormente transformado em DB, acima do qual todas as árvores foram incluídas no levantamento.

Os dados obtidos em campo foram o perímetro do caule na base (PB) e a altura máxima (h).

O cálculo de biomassa vegetal aérea foi feito aplicando a equação alométrica representada pela Equação 5, publicada por Abdala et al. (1998). Esta equação foi desenvolvida com a finalidade de calcular a biomassa aérea de árvores do bioma cerrado no Brasil Central.

$$
\log (y)=0,9967 \log (x)+2,587
$$

Onde:

$\mathrm{y}=$ peso total do indivíduo $(\mathrm{g})$

$\mathrm{x}=$ volume cilíndrico $\left(\mathrm{dm}^{3}\right)$

O volume cilíndrico foi calculado como o produto da área basal média $(\mathrm{AB})$ e a altura do fuste.

Os valores das variáveis biofísicas levantadas para as 800 árvores amostradas estão listados no Anexo 1. 


\subsection{Processamento de dados de sensoriamento remoto}

Neste trabalho foi utilizada uma imagem ETM+ Landsat7, correspondente à órbita / ponto 221/76 do sistema de referência (WRS). A data de aquisição da imagem é 5 de junho de 2002. Também foram utilizadas duas imagens do sistema TM Landsat5 adquiridas nos dias 22 de julho de 1993 e 20 de maio de 1999. Esses dois sistemas produzem imagens na faixa óptica do espectro eletromagnético. Todas as imagens foram georreferenciadas mediante pontos de controle obtidos no campo com um receptor GPS e na carta topográfica Campos Novos Paulista (IBGE, 1975). Em todos os casos o erro se manteve abaixo de meio pixel.

Também foi utilizada uma imagem do satélite japonês JERS-1 do dia 20 de dezembro de 1995 na órbita / ponto 389/-338. A imagem foi processada pela NASDA em 4 de setembro de 2000. Este satélite operava na região espectral das microondas, especificamente na banda L, cujo comprimento de onda é de aproximadamente $23 \mathrm{~cm}$. As imagens do Landsat TM 5 foram processadas com os programas Idrisi 32 e Spring 3.6. Os processamentos digitais das imagens ETM+ Landsat 7 e do satélite JERS-1 foram realizados no programa ENVI 3.4.

\subsubsection{Correção atmosférica}

As bandas 1 (azul), 3 (vermelho) e 4 (infravermelho próximo) da imagem ETM+ foram submetidas a um processamento digital para correção dos efeitos da atmosfera. Este processamento foi feito com o programa 6S 4.1 (ANTUNES, 2001). O modelo permite calcular a reflectância real de cada pixel em uma imagem. Os parâmetros de entrada utilizados para a correção atmosférica foram:

- Dia e mês de aquisição da imagem: 5 de junho

- Hora universal de aquisição da imagem em unidades decimais: 13.05 
- Latitude e longitude do centro da cena: $-50.455761-24.061781$

- Modelo atmosférico: foi selecionado o modelo tropical

- Modelo de aerossol: foi selecionado o modelo continental, pois a área de estudo está relativamente longe do mar.

- Concentração dos aerossóis: foi selecionada a opção "a partir da visibilidade"

- Visibilidade: $25 \mathrm{~km}$.

Todas as bandas ETM+ utilizadas neste trabalho foram gravadas no modo de alto ganho. Por esse motivo, não foi necessário corrigir os efeitos que poderiam derivar de uma gravação da imagem com baixo ganho.

\subsubsection{Georreferenciamento das imagens ópticas}

As imagens Landsat ETM+ foram georreferenciadas mediante 11 pontos de controle adquiridos com o auxílio de um GPS. O erro do processo de georeferenciamento foi mantido inferior a 15 metros, equivalente a meio pixel da imagem.

\subsubsection{Georreferenciamento da imagem JERS-1}

A imagem SAR foi lida e recortada no programa ENVI 3.5 e também foi georreferenciada com o auxílio do mesmo software. A imagem óptica proveniente do sensor ETM+ foi utilizada como base para a seleção dos pontos de controle que posteriormente foram utilizados para georreferenciar a imagem SAR. Outra alternativa teria sido georreferenciar a imagem SAR baseando-se na carta topográfica da área de estudo. Entretanto, optou-se por utilizar a imagem óptica porque geralmente é mais fácil identificar as feições nelas do que em mapas. O fato da base cartográfica ser de 1995 também foi um motivo para essa escolha. 
A imagem JERS-1 tem uma resolução geométrica de 18 m. Esta é menor que a ETM+, cuja resolução geométrica é $30 \mathrm{~m}$. Devido a esta diferencia de resoluções e pelo fato de ter se utilizado como base a imagem com pixels de maiores dimensões, incorreu-se em um erro no registro da imagem JERS-1. O erro máximo está definido pelo erro acumulado no georreferenciamento da imagem ETM+, ou seja, $15 \mathrm{~m}$, e o erro do processo de registro da imagem JERS-1, que também é meio pixel, ou seja, $24 \mathrm{~m}$. Assim, o erro de posicionamento na imagem JERS-1 é, no máximo, de 24 m.

\subsubsection{Geração de imagens índice}

Duas imagens IVDN foram geradas a partir das bandas 3 (vermelho) e 4 (infravermelho próximo) das imagens Landsat órbita-/ponto 221/76. Uma a partir da imagem TM de 20 de maio de 1999 e a outra a partir da imagem ETM+ com data de aquisição 5 de junho de 2002. Em ambos casos foi utilizada a Equação 1.

A imagem IVR foi gerada a partir das bandas 1 (azul), 3 (vermelho) e 4 (infravermelho próximo) da imagem ETM+. Para o cômputo desta imagem foi usada a Equação 2 com os mesmos coeficientes utilizados para a elaboração das imagens IVR a partir de dados do sensor MODIS.

\subsection{Metodologia para integração e análise de dados de campo e sensoriamento remoto}

O trabalho desenvolvido consistiu basicamente de duas partes:

A) Comparação dos dados de IAF com os de IVDN e IVR: foram estimados os valores de IAF das nove áreas que apresentam vegetação aberta do bioma cerrado (1A até 9A). Essas estimativas foram feitas com o analisador de dosséis vegetais LAI-2000. Os resultados foram comparados com os valores extraídos das imagens IVDN e IVR. 
B) Comparação dos dados de biomassa florestal aérea com os de retroespalhamento da imagem JERS-1: Foi determinada a biomassa florestal aérea média em cada uma das dez áreas homogêneas (1B até 10B), cobertas por vegetação lenhosa densa. Estas áreas apresentam grande variação entre si na quantidade de biomassa florestal aérea, porém são homogêneas internamente em sua quantidade e distribuição de biomassa lenhosa aérea. A seguir, esses valores de biomassa determinados foram comparados com os valores de retroespalhamento extraídos da imagem JERS-1. Além da biomassa, também foram comparados os valores de Área basal média (AB) e distância entre as árvores com os valores de retroespalhamento da imagem JERS-1.

As áreas 1B a 10B utilizadas nesta etapa são diferentes das 1A a 9A, utilizadas na primeira parte do trabalho.

\subsubsection{Relação entre Î́ndice de Área Foliar e Índices de Vegetação em áreas} abertas

Os valores médios de IAF estimados através do levantamento no campo com o dispositivo LAI-2000 para cada área, foram posteriormente relacionados aos valores médios de IVDN e IVR para as áreas correspondentes na imagem ETM+ de 2002.

\subsubsection{Caracterização da relação entre biomassa florestal aérea e imagens de radar em áreas de fisionomias florestais}

A segunda parte do trabalho consistiu em determinar uma função que relacionasse os dados de quantidade de biomassa aérea lenhosa de áreas cobertas por vegetação com fisionomias florestais e o sinal registrado nas imagens de radar na banda L. Para tanto, os dados de biomassa necessários foram coletados no campo através das técnicas descritas no próximo item, enquanto que a metodologia utilizada para a extração e tratamento dos dados das imagens de radar está descrita no item 4.3.2. 


\subsubsection{Processamento digital da imagem de radar}

As coordenadas geográficas de cada área amostrada foram coletadas no campo com um receptor GPS. Estes pontos serviram para definir as regiões de amostragem do sinal de retroespalhamento registrado nas imagens de radar georreferenciadas.

A seguir, na imagem JERS-1, foram delimitadas áreas representativas em torno de cada ponto correspondente a cada uma das áreas amostradas no campo, como ilustra a Figura 19. Os valores de retroespalhamento considerados foram os valores médios para cada área.

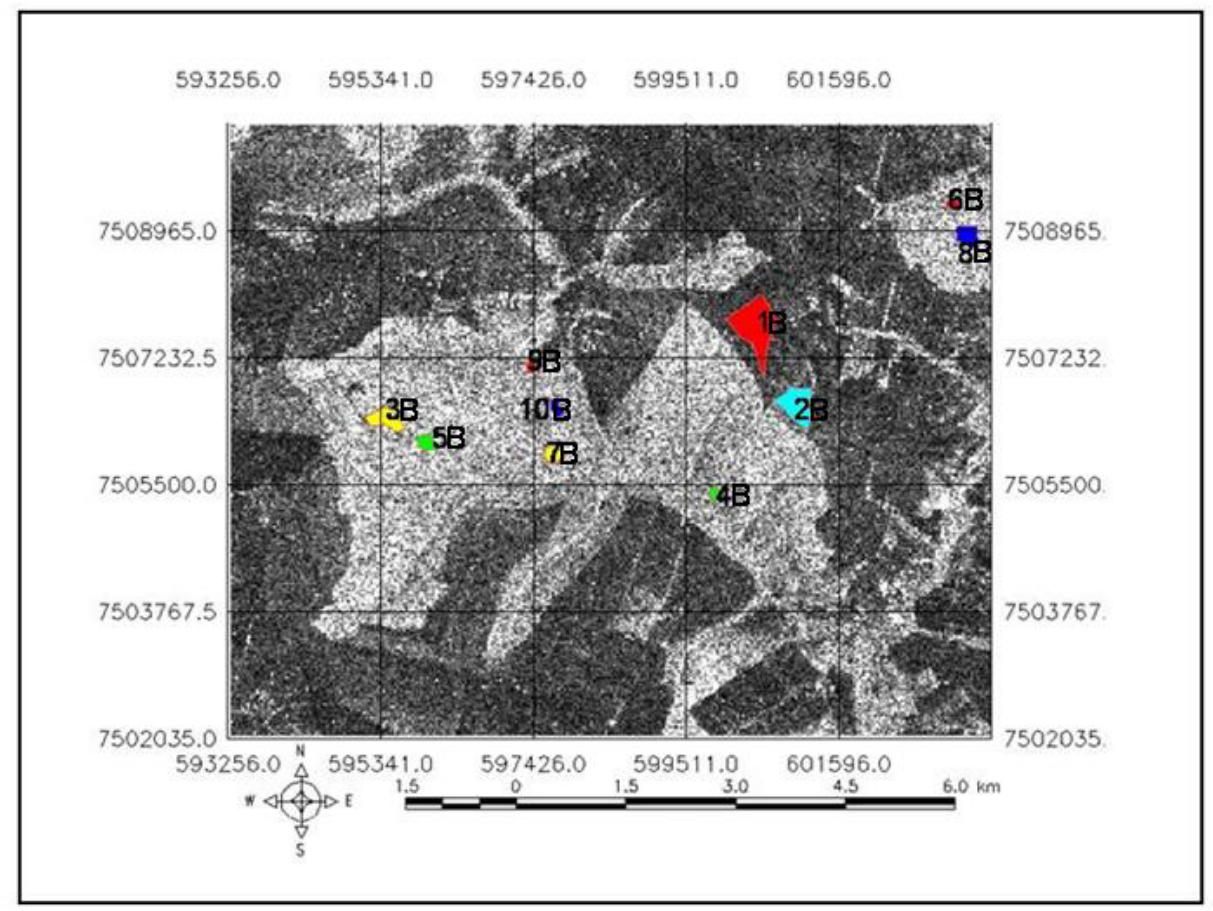

Figura 19. Imagem JERS-1 da área de estudo, mostrando os locais onde foram amostrados os valores de retroespalhamento e de biomassa no campo. A numeração está de acordo com a Tabela 5.

A Figura 19 mostra uma imagem representada em tons de cinza onde as manchas claras correspondem aos remanescentes de cerrado que coincidem com o mapeamento 
realizado por Kronka et al. (1993). As áreas escuras apresentam algum tipo de atividade antrópica. Na região prevalecem as atividades agropastoris.

Os valores dos pixels, originalmente em número-digital, foram convertidos em decibéis (dB), com o objetivo de obter resultados em unidades comparáveis com outros da literatura. Isto foi feito através da Equação 3.

Obtiveram-se assim os seguintes conjuntos de dados:

a) Nas áreas de fisionomias florestais:

-valores médios de biomassa lenhosa aérea (T/ha) determinados no campo para cada área amostrada;

•valores médios de retroespalhamento (número-digital e $\mathrm{dB}$ ) extraídos das áreas correspondente às amostradas no campo na imagem JERS-1.

b) Nas áreas de vegetação aberta:

-valores médios de IAF determinados no campo com o LAI-2000 para cada área amostrada;

-valores médios de IVDN e de IVR, extraídos das áreas correspondente às amostradas no campo, de imagens transformadas em reflectância real e corrigidas para efeitos atmosféricos.

Foram determinadas equações que representassem as relações entre os seguintes conjuntos de valores:

- Biomassa lenhosa aérea e retroespalhamento $(\sigma)$ em números digitais (nd);

- Biomassa lenhosa aérea e retroespalhamento $(\sigma)$ em decibéis $(\mathrm{dB})$;

- IAF e IVDN;

- IAF e IVR. 


\section{5 - Resultados e discussão}

Os resultados são apresentados em duas partes: inicialmente, aqueles derivados da análise das imagens índice de vegetação nas áreas mais abertas; a seguir, os resultados que levaram em consideração os valores extraídos a partir das imagens de radar das fisionomias nas quais predomina o componente florestal.

\subsection{Relação entre Índice de Área Foliar e Índices de Vegetação em áreas abertas}

A Tabela 7 lista os valores médios dos dados de IAF, de IVDN e as coordenadas de cada uma das áreas amostradas nesta parte do trabalho. A ordem de apresentação é de valores decrescentes de IAF.

TABELA 7. Coordenadas planas e valores médios de IAF e de IVDN das áreas amostradas.

\begin{tabular}{cccc}
\hline Área & Coordenadas UTM 22S & IAF & IVDN \\
\hline 1A & 5978367508560 & 3,57 & 0,46 \\
2A & 5955247506326 & 3,21 & 0,66 \\
3A & 5970707507630 & 2,74 & 0,66 \\
4A & 5961897507706 & 2,28 & 0,60 \\
5A & 5968007507690 & 2,15 & 0,54 \\
$6 \mathrm{~A}$ & 5966267506712 & 1,31 & 0,67 \\
7A & 5988487506476 & 0,97 & 0,60 \\
8A & 5953907506500 & 0,82 & 0,72 \\
9A & 5986687506499 & 0,46 & 0,52 \\
\hline
\end{tabular}

Os valores médios de IAF determinados em campo ficaram dentro dos limites esperados $(\sim 0,5$ a $\sim 3,6)$. O menor valor médio de IAF foi de 0,46 (área 9A). Esse valor é o 
resultado de 14 medidas em uma área de cerrado stricto sensu, com predomínio de árvores de aproximadamente 1,5 metro de altura. Essas árvores são consideradas baixas dentro do contexto da área de estudo. O baixo valor de IAF determinado pode ser devido à época do ano em que foi realizado o trabalho de campo, de início de estiagem.

As várias fisionomias vegetais do bioma cerrado sofrem efeitos distintos em relação à sazonalidade, sendo que esse fenômeno é determinado pela disponibilidade hídrica. As fisionomias mais florestais, constituídas pelo cerradão e ecótonos com florestaestacional semi-decidual, apresentam menor variação temporal na quantidade de folhas verdes entre os períodos seco e úmido. Por outro lado, as fisionomias mais abertas, apresentam maior variação sazonal na quantidade de folhas verdes presentes. A perda de folhas é máxima no período seco, sendo provavelmente um dos motivos que ocasionou o registro do valor 0,52 de IVDN naquele momento de início da estiagem. $\mathrm{O}$ fogo também é freqüente nesta época, devido à acumulação de material vegetal seco na superfície do solo, o qual constitui um ótimo combustível. As queimadas normalmente eliminam, além da serapilheira, qualquer órgão fotossintetizante. Deste modo, provocam uma diminuição brusca dos valores de IVDN. No entanto, durante o trabalho de campo para determinar os valores de IAF, não foram detectadas evidências do acontecimento de queimadas recentes nas áreas amostradas. Por este motivo, os baixos valores de IAF parecem ter sido originados por causa do reduzido número de folhas, relacionado à sazonalidade dessa fisionomia do cerrado e à ação do gado que invade continuamente os remanescentes de cerrado. Os principais efeitos prejudiciais do gado na vegetação são o consumo e o pisoteio. O estrato herbáceo é o que apresenta maior sensibilidade a estes dois efeitos. 
A heterogeneidade do ambiente, determinada pela alternância entre pastos e árvores, provavelmente foi a responsável pela grande variação dos valores de IAF coletados na área. Das 14 medições feitas para obter o valor médio de 0,46 , o maior valor registrado foi 0,71 , enquanto que, em duas leituras, foi registrado o valor 0,00. Estas duas medições provavelmente foram feitas em pontos nos quais não havia árvores na área visualizada pelos detectores do LAI-2000. A leitura 0,71 provavelmente foi feita em um ponto próximo de uma árvore e a influência dele na leitura pode ter ocasionado o valor mencionado, o qual mesmo assim, é considerado baixo.

A próxima área com menor IAF é a $8 \mathrm{~A}$. $\mathrm{O}$ valor médio dos dados de IAF coletadas em esta área foi de 0,82. Esse valor foi resultado de uma média de 46 leituras, representando o maior esforço amostral dentro de todas as áreas avaliadas através do analisador de dosséis LAI-2000. Isto se deveu a que é a maior área amostrada e foi preciso realizar medições em vários transectos a fim de caracterizar adequadamente a sua variação interna. Também neste caso a área está coberta por uma fisionomia de cerrado stricto sensu baixo. A cobertura herbácea do solo neste setor apresenta diferenças importantes comparada com as da área 9A. Na área 8A o estrato herbáceo encontra-se dominado por ciperáceas e há muitas bromélias de solo. Isso permite inferir que o solo apresenta algum tipo de mudança, quando comparado ao da área anterior. Essas diferenças no substrato poderiam ocasionar diferenças inclusive na vegetação arbórea. Por essa razão, esta área também foi selecionada para amostragem.

Das 46 medições feitas na área 8A, 23 tiveram valor 0,00, enquanto o maior valor registrado foi 3,11. A maior variação dos valores registrados nesta área, quando comparados com os da área anterior, provavelmente é resultado do maior esforço 
amostral. O valor médio de IVDN obtido para esta área (8A) a partir da imagem é 0,72 . Este valor é considerado alto para ser devido somente às folhas das árvores. $\mathrm{O}$ valor médio de IAF determinado através do analisador de dosséis vegetais sugere a ocorrência de um valor de IVDN menor. A possível explicação destes registros discordantes é que o LAI-2000 subestimou a quantidade de folhas verdes na área. As folhas do estrato herbáceo que cobre o solo podem ter contribuído para incrementar o valor de IVDN. As características da vegetação do estrato herbáceo presente na área permitem suspeitar que a umidade do solo seja suficiente para mantê-lo verde o ano todo.

O maior valor médio de IAF registrado em todas as regiões amostradas dentro da área de estudo atingiu o valor de 3,57. Esse valor está dentro da zona de saturação do IVDN na qual este índice não permite estimar dados confiáveis de biomassa e vice-versa. Este valor foi resultado da média aritmética dos valores coletados na área 1A, a qual corresponde a uma mata ciliar, localizada à beira de um córrego que atravessa a Fazenda Alvorada de Bragança. A vegetação nessa área é mais densa do que nas outras regiões amostradas em essa parte do trabalho, pois provavelmente ela nunca se encontre submetida a estresse hídrico. Um possível aporte de sedimentos pelo curso de água também pode ser a causa de que a vegetação aqui seja tão densa. Por esses motivos, seria esperável que o valor de IVDN coletado nesta área estivesse próximo de um, valor máximo que o índice assume. No entanto, o valor médio extraído da imagem foi 0,46 , correspondente a uma menor cobertura vegetal do que a encontrada na área amostrada. Este valor reduzido $(0,46)$ pode ser explicado pelo fato de que a mata ciliar é muito estreita, menos de 10 metros em cada margem do curso de água, e os valores dos pixels podem estar contaminados pelo sinal originado na cobertura da matriz de pastagem, na qual se insere a mata ciliar. 
$\mathrm{O}$ segundo maior valor médio de IAF foi determinado na área $2 \mathrm{~A}$, a partir de um conjunto de 13 leituras registradas com o LAI-2000, em uma área de cerrado aberto e rodeada por cerradão. Essa área corresponde a um tipo de vegetação transicional do ponto de vista da quantidade de biomassa. A Oeste, o solo está coberto por pastagem implantada, apresentando algumas árvores de grande porte distanciadas entre si. Provavelmente, essas árvores são remanescentes de uma fisionomia tipo cerradão que cobria a área no passado. Atualmente, o cerrado que cobre a área amostrada é baixo e aberto. Próxima a essa área, há uma região coberta exclusivamente por Pteridium spp. Ao redor da área amostrada, o solo está coberto por cerradão. O valor médio de IAF foi 3,21 e o IVDN, calculado como a média aritmética a partir dos valores dos pixels da imagem, foi 0,66 .

A área 3A fica localizada próxima de um depósito de lixo dentro da Fazenda Alvorada de Bragança. Ela foi selecionada devido à escassa cobertura florestal presente, o que a torna adequada ao monitoramento através de imagens índice de vegetação. Essa área apresentou um valor médio de IAF de 2,74, relativamente alto para os valores esperados. O valor médio de IVDN extraído a partir da imagem foi de 0,66. Este valor é considerado alto para as condições da vegetação do lugar, porém é condizente com o valor médio de IAF registrado.

$\mathrm{Na}$ área 4A, o valor médio de IAF foi de 2,28, enquanto que o IVDN foi de 0,60. Essa área corresponde a um cerrado fechado, relativamente denso, alto e com abundantes folhas verdes.

A área 5A, encontra-se ocupada por cerrado stricto sensu baixo e aberto, mais ralo que o encontrado na área 4A. Nesse caso, ao contrário dos outros pontos cobertos por 
vegetação com estas características, o solo encontrava-se coberto por serapilheira, sem evidências de ação do fogo em um passado recente. A maioria das árvores estava desprovida de folhas, havendo abundância de ciperáceas no estrato herbáceo. O valor médio de IAF foi 2,15 , que é considerado alto para a quantidade de cobertura vegetal presente no campo. Acredita-se que os registros de IAF coletados incluam uma interferência do material lenhoso das árvores e arbustos, tendo-se superestimado os verdadeiros valores deste parâmetro. O valor de IVDN foi 0,54 , valor considerado alto devido à pouca quantidade de material vegetal verde presente na área, no momento da aquisição da imagem pelo sensor do satélite.

A área 6A foi amostrada através de 10 medidas do LAI-2000. O valor médio calculado para o parâmetro IAF foi 1,31 e o IVDN foi 0,67 , valores que são considerados consistentes com o tipo de vegetação presente no local, isto é, cerrado stricto sensu denso.

Para a última área considerada neste estudo (7A), o valor de IAF foi 0,97 , enquanto que o valor de IVDN foi 0,60 . O solo desta região encontra-se coberto por cerrado denso e baixo de aproximadamente 1,5 metro de altura.

A maioria das regiões amostradas (78\%) apresentaram valores médios de IAF menores que 3,0 e não foi registrado nenhum valor igual ou maior a 4,0. Fundamentalmente, esse resultado pode ser devido à seleção intencional de áreas com vegetação rala na região de estudo. Locais cobertos por vegetação que apresentem valores superiores de IAF poderiam não ter a sua biomassa estimada através de índices de vegetação. 
Tanto os valores de IAF derivados das medições feitas com o LAI-2000 quanto os valores de IVDN registrados na imagem apresentaram grande variação dentro de cada área amostrada.

Os valores numéricos contidos nas imagens índice de vegetação integram o sinal da radiação refletida por toda a vegetação presente na área que é recebido pelo sensor. Assim, em vegetação aberta, como as que foram consideradas nessa parte do trabalho, a energia refletida tanto pela porção verde da vegetação herbácea quanto pela lenhosa é capaz de sensibilizar o dispositivo a bordo da plataforma orbital. Como resultado disso, os dados contidos na imagem integram tanto as informações provenientes das folhas das árvores e arbustos quanto as do estrato herbáceo da área de estudo.

A amostragem em campo foi realizada exclusivamente na vegetação florestal, sendo que o estrato herbáceo não foi avaliado em nenhum momento. Durante a estação seca, a parte aérea da cobertura herbácea do cerrado em geral morre, principalmente nas áreas pouco modificadas pela ação humana. As áreas mais antropizadas, freqüentemente incluem uma grande proporção de gramíneas exóticas, que conservam suas folhas verdes por mais tempo que as espécies nativas do cerrado. A área de estudo compreende duas manchas de cerrado e cerradão inseridas em uma matriz de pastagem cultivada com espécies exóticas. O constituinte herbáceo da vegetação na área pode ter sido, em parte, responsável pela variabilidade dos resultados obtidos.

As árvores e arbustos presentes na área se distribuem de forma não agregada, porém há várias áreas com menor densidade destes indivíduos, que podem ser classificadas como clareiras. Por causa da interação da geometria de iluminação com a heterogeneidade da cobertura vegetal, observam-se muitas áreas sombreadas. A sombra influencia 
distintamente os valores registrados nas diferentes bandas espectrais. Conseqüentemente, os valores dos índices de vegetação derivados das imagens carregam os erros desta fonte (FERREIRA et al. 2004) e podem ser responsáveis pelos desvios registrados a partir dos valores esperados.

Esperava-se que os dados de IAF e IVDN apresentassem correlação não linear, do tipo logarítmica, segundo a qual os incrementos nos valores de IAF corresponderiam com incrementos cada vez menores nos valores de IVDN, até estabilizarem-se em valores de IAF próximos de três, segundo a Figura 6.

Os dados coletados, no entanto, mostram uma grande dispersão dos valores de ambas variáveis. Em uma primeira análise visual, parece não haver correlação entre as variáveis representadas por estes dados.

A hipótese de correlação linear entre IVDN e IAF foi verificada por meio do teste de Pearson no aplicativo Statistica 5.1 (STASOFT, 1996). O resultado da análise realizada entre os valores das amostras de ambas variáveis forneceu um valor de $p=0,3904$, o qual é muito maior que o limite alfa $(0,05)$. Dessa forma, foi descartada a hipótese de correlação linear entre as variáveis.

A imagem IVDN de 5 de junho de 2002 está apresentada na Figura 21. Os polígonos correspondentes às áreas onde foram feitas determinações do IAF com o LAI-2000 estão desenhados em diferentes cores e numerados na mesma seqüência apresentada na Tabela 7. 
A Figura 20 representa a dispersão dos valores das amostras coletadas de IVDN e IAF. O resultado do teste não permite afirmar a existência uma relação entre as variáveis.

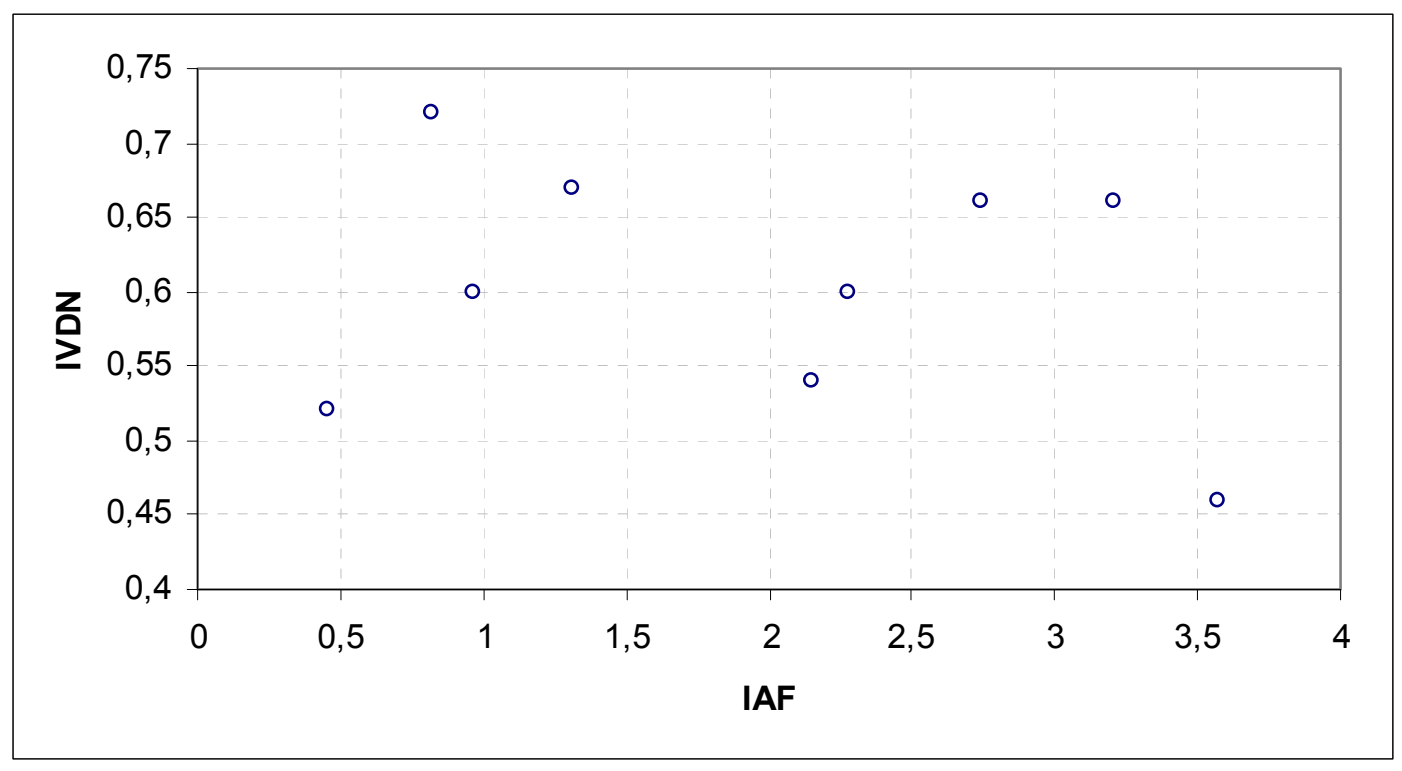

Figura 20. Distribuição dos valores médios de IVDN e IAF na área amostrada. $(\mathrm{r}=0,238 ; \mathrm{p}=0,3904)$.

Como já foi mencionado, o IVR, foi desenvolvido especificamente para aplicações com imagens do sensor MODIS e os coeficientes necessários para o cômputo do índice foram determinados para a altura, a localização e a largura das bandas em que opera esse sensor. A utilização deste índice de vegetação, a partir de dados coletados por sensores que operam em outras faixas espectrais, tem sendo feita apesar dos valores dos coeficientes utilizados serem aqueles determinados para o MODIS (FERREIRA et al. 2004). O erro decorrente da utilização desses coeficientes não foi avaliado, mas apesar disso, o uso dessa metodologia com os mesmos coeficientes, é sugerida por pesquisadores da própria instituição que desenvolveu o sensor e o IVR (HUETE, 2003 comunicação pessoal). 


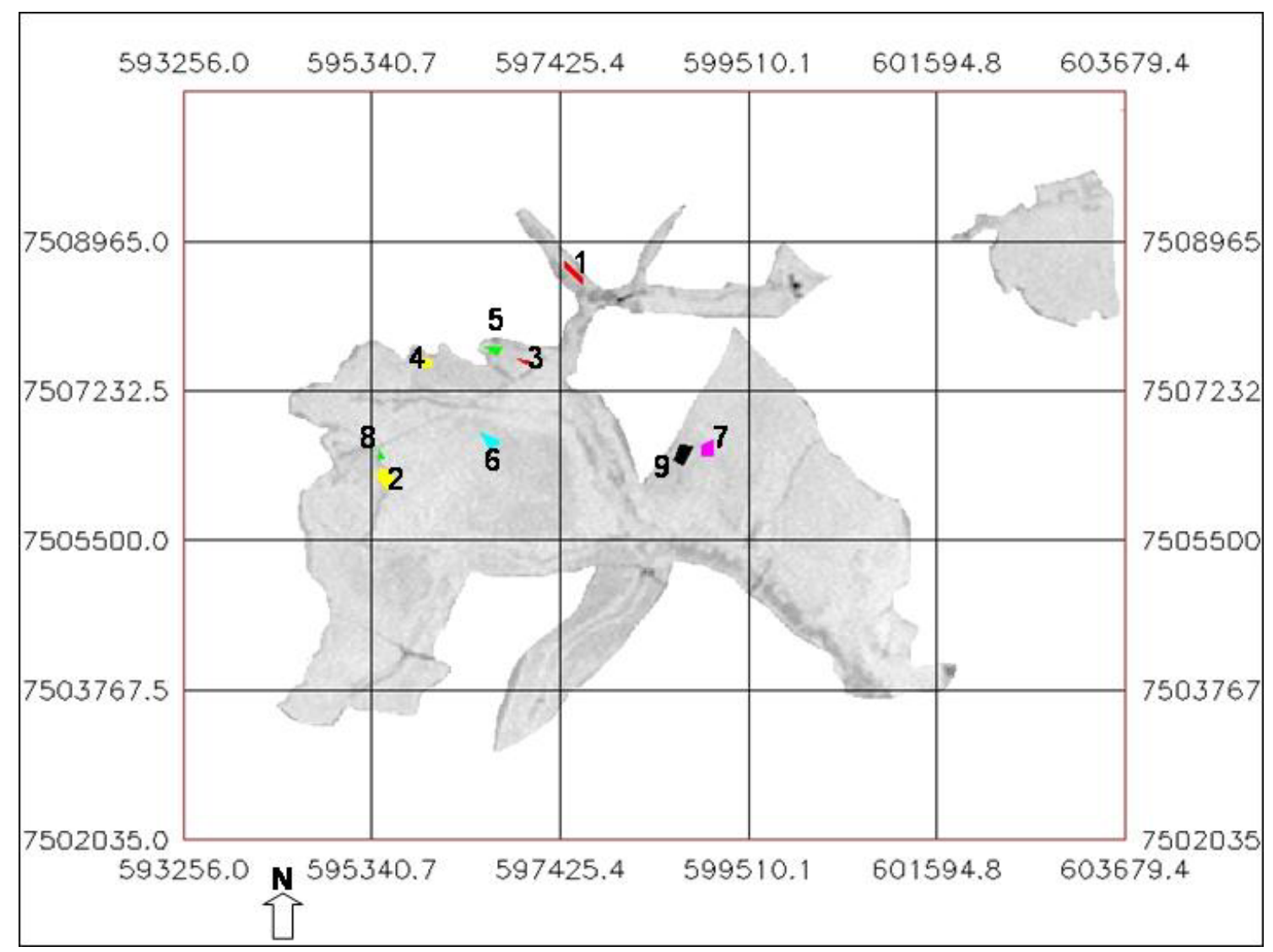

Figura 21. Imagem IVDN de 5 de junho de 2002 com a localização das as áreas de vegetação aberta amostradas.

Foram utilizadas as mesmas áreas tanto para extrair os valores da imagem IVDN quanto para extrair os valores correspondentes da imagem IVR. Essa última imagem está representada na Figura 22, ilustrando as áreas amostradas.

A Tabela 8 mostra os valores médios de IAF, IVDN e de IVR das áreas amostradas nesta parte do trabalho. 


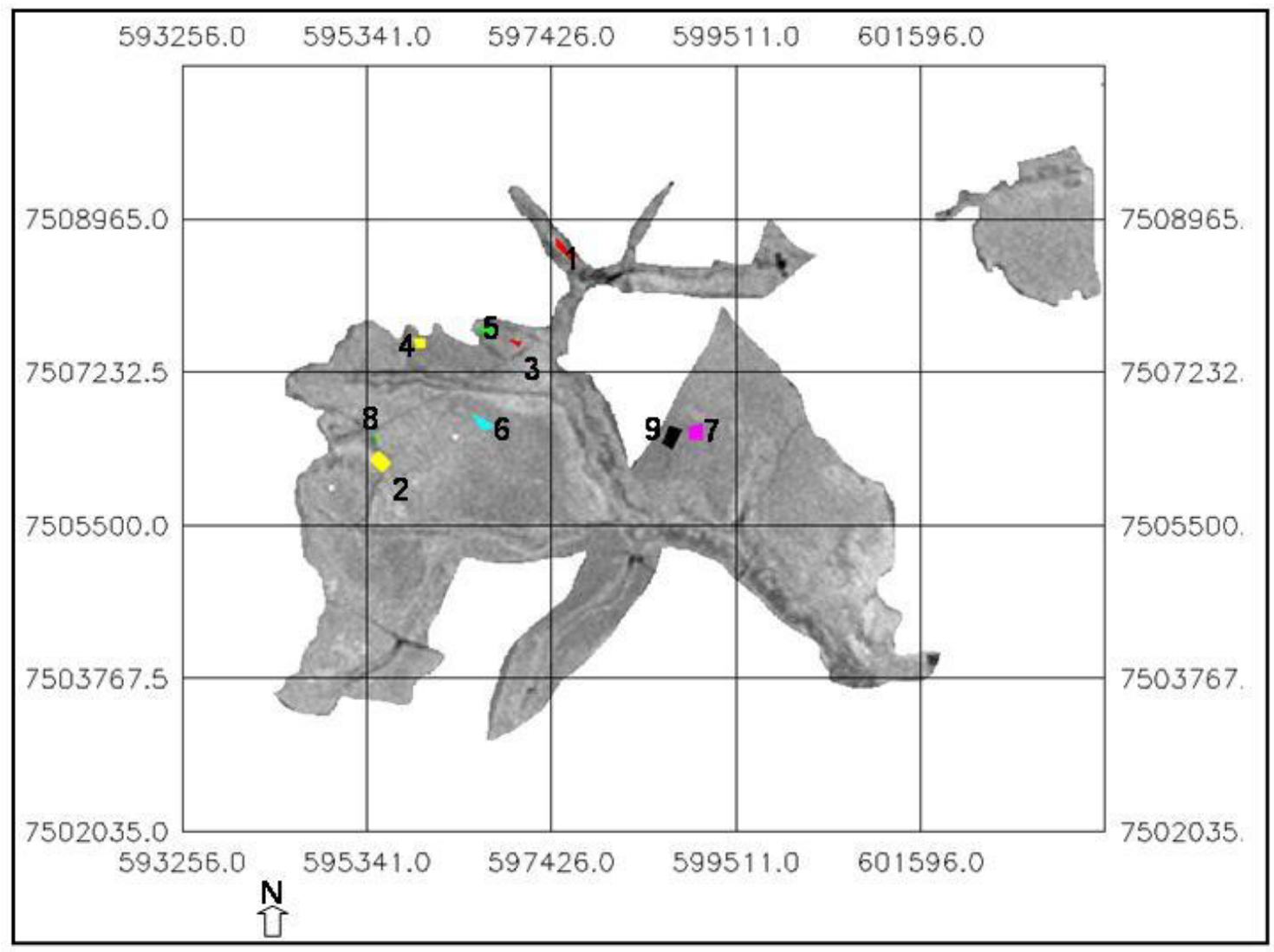

Figura 22. Imagem IVR de 5 de junho de 2002 com a localização das áreas amostradas de vegetação aberta. As áreas são as mesmas que as da imagem IVDN.

A variação dos valores de IVR em relação às mudanças dos valores do IAF nas áreas amostradas é menor que a variação dos valores do IVDN. Essa tendência está de acordo com o observado por Ferreira et al. (2004). Os valores máximos e mínimos dentro da área de estudo foram 0,26 e 0,18 respectivamente. Ferreira et al. (2004), trabalhando com imagens índice de vegetação elaboradas a partir de imagens MODIS para áreas de cerrado e cerradão no Parque Nacional de Brasília, encontraram valores de IVR entre 0,26 e 0,32 e IVDN entre 0,55 e 0,67 para as mesmas áreas. No entanto, deve-se considerar que os valores dos coeficientes utilizados na equação de cálculo do IVR possivelmente não são adequados para as imagens do sensor ETM+ Landsat7. A Figura 23 representa a distribuição dos valores amostrados de IVR e IAF na área de estudo. 


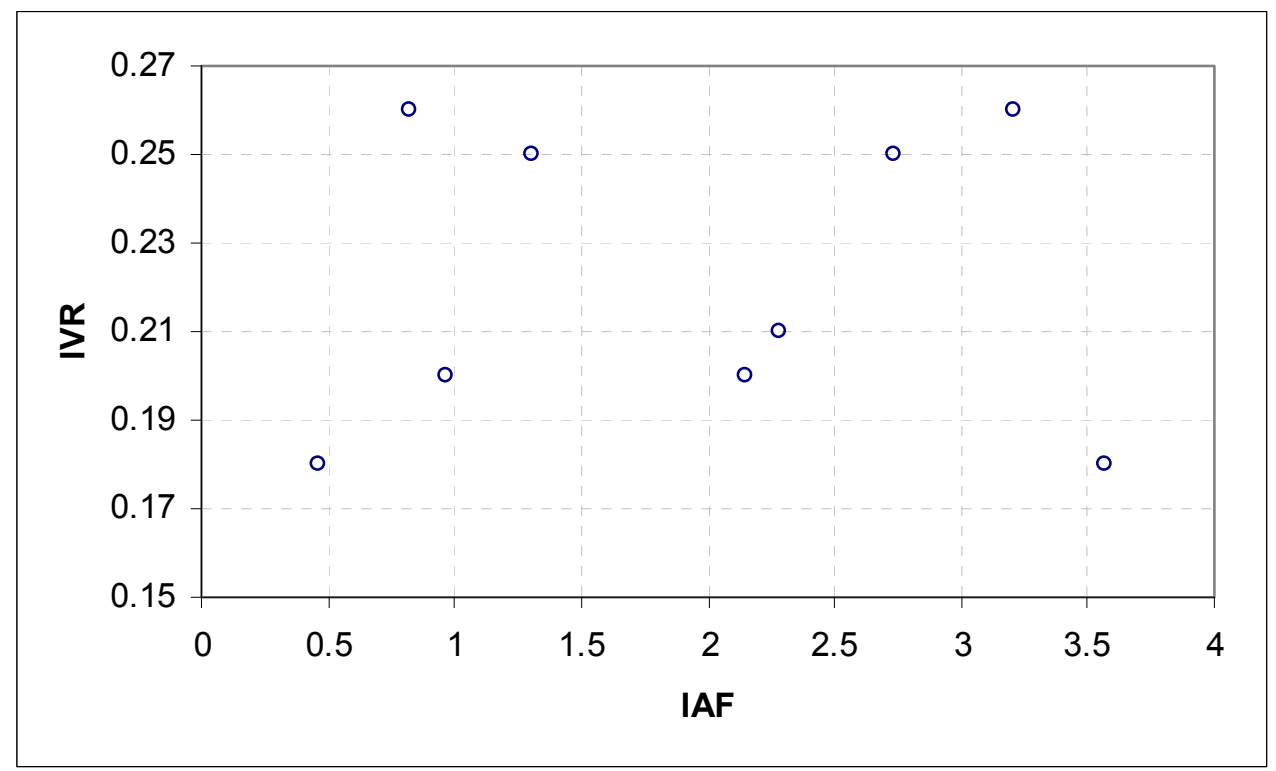

Figura 23. Distribuição dos valores médios de IVR e IAF nas áreas amostradas.

Outra fonte de erro nos valores de IVR pode ter origem no processo de correção atmosférica. Os dados de entrada do modelo $6 \mathrm{~S}$ utilizados durante esse processamento foram estimados, podendo ter influenciado os valores, principalmente da banda 1 . Os valores de reflectância dos pixels desta banda estão submetidos a os dois tipos de espalhamento, o Mie e o Rayleigh. Os valores dessa banda estão incluídos na equação para o cálculo do índice, o que não acontece no caso do IVDN.

Os problemas de amostragem do IAF, mencionados quando foram discutidos os resultados do IVDN, também são aplicáveis aos resultados do IVR, pois, em ambos os casos foi utilizado o mesmo conjunto de dados. 
TABELA 8. Valores médios de IAF e de IVR das áreas amostradas.

\begin{tabular}{cccc}
\hline Área & Coordenadas UTM 22S & IAF & IVR \\
\hline 1A & 5978367508484 & 3,57 & 0,18 \\
2A & 5955247506326 & 3,21 & 0,26 \\
3A & 5969167507590 & 2,74 & 0,25 \\
$4 \mathrm{~A}$ & 5961897507706 & 2,28 & 0,21 \\
$5 \mathrm{~A}$ & 5969237507650 & 2,15 & 0,20 \\
$6 \mathrm{~A}$ & 5966267506712 & 1,31 & 0,25 \\
$7 \mathrm{~A}$ & 5988487506476 & 0,97 & 0,20 \\
$8 \mathrm{~A}$ & 5955007506500 & 0,82 & 0,26 \\
$9 \mathrm{~A}$ & 5986687506499 & 0,46 & 0,18 \\
\hline
\end{tabular}

5.2. Caracterização da relação entre biomassa florestal aérea e imagens de radar em áreas de fisionomias florestais

A metodologia utilizada para o levantamento das variáveis biofísicas (DB e altura), a seleção da estratégia de amostragem através do método de quadrantes centrados e o cálculo posterior de biomassa lenhosa aérea por meio de equações alométricas apropriadas permitiram caracterizar um amplo espectro da vegetação.

Os valores resultantes do cálculo de biomassa através da equação desenvolvida por Delitti et al. (2002) foram, em média, 3,5\% maiores que os fornecidos pela equação publicada por Abdala et al. (1998). O fato de que o cálculo dessa variável por dois métodos diferentes tenha fornecido resultados similares, sugerem uma boa representatividade dos valores utilizados. Assim, foram computados valores de biomassa lenhosa aérea em uma amplitude desde 1,7 T/ha. até 124,36 T/ha.

A Tabela 9 resume os resultados das variáveis biofísicas dos levantamentos feitos no campo, as coordenadas centrais dos locais de coleta, os dados de biomassa calculados, 
bem como os valores médios de retroespalhamento na imagem JERS-1 para cada área. As áreas estão numeradas de acordo com a Figura 19.

A área 1B corresponde a uma área antigamente ocupada por cerradão, na qual a vegetação florestal foi quase totalmente retirada para a implantação de pastagem. O objetivo do proprietário foi destinar essa área para a criação de gado. Portanto, a maioria das árvores foi cortada e a regeneração tem sido evitada continuamente. Nesta área, foram mantidos alguns indivíduos de grande porte com a finalidade de fornecer sombra para o gado. $O$ valor médio de $A B$ nesta área de coleta é $0,55 \mathrm{~m}^{2} /$ ha e a biomassa aérea média dos indivíduos é de 240,62 kg. Essas árvores, no entanto, encontram-se muito esparsas. Isso se evidencia pela distância média entre os indivíduos calculada em $38,3 \mathrm{~m}$. O grande distanciamento entre as árvores, com a conseqüente diminuição da competição por luz, água e nutrientes, pode ter contribuído para o aumento do tamanho dos indivíduos. As árvores com maior biomassa foram encontradas nessa área, porém elas se encontram em número muito pequeno: apenas 6,8 árvores/ha. $\mathrm{O}$ valor de retroespalhamento médio nessa área é de $-14,87 \mathrm{~dB}$ e o valor de biomassa lenhosa aérea $1,7 \mathrm{~T} / \mathrm{ha}$.

$\mathrm{A}$ área $2 \mathrm{~B}$, com segundo menor valor de biomassa por hectare, corresponde a uma região localizada ao Sul da área $1 \mathrm{~B}$. O aspecto visual em campo leva a supor que é possível que as duas áreas originalmente tivessem coberturas vegetais similares. A vegetação florestal nesta área também foi parcialmente retirada, com o mesmo objetivo de implantar pastagem e dedicar a área para a criação de gado. No entanto, foram preservados mais indivíduos arbóreos que na área 1B para fornecer sombra, restando 28 árvores/ha. Devido a essa prática de manejo, os valores de biomassa por unidade de área são maiores que os da área $1 \mathrm{~B}$. $\mathrm{A} \mathrm{AB}$ é de $1,66 \mathrm{~m}^{2} / \mathrm{ha}$, mais do triplo do valor 
determinado na primeira área, o que é condizente com o fato de haver maior número de árvores por unidade de área. Todavia, a biomassa média por indivíduo é 178,54 kg, menor do que a determinada na área 1B. O menor tamanho das árvores não estaria determinado pela competição por recursos, como poderia se cogitar em uma primeira análise. A distância média entre as árvores é de aproximadamente 19 metros, o que discorda com essa hipótese de competição. As árvores maiores têm sido preservadas, assim como na área anterior. Entretanto, na área 2B, o número de indivíduos é maior, o que necessariamente implica em ter selecionado todas as árvores grandes e também algumas de menores dimensões que na primeira. Esse procedimento provavelmente seja o responsável pelo menor valor de peso médio das árvores.

Essa maior proximidade entre as árvores resulta em maiores valores de biomassa por unidade de área, apesar do menor tamanho dos indivíduos. Assim, a distância média entre eles é de 18,82 m. O valor de retroespalhamento médio nesta área é de $-11,36 \mathrm{~dB}$. e o valor médio de biomassa é de 5,04 T/ha.

A área $3 \mathrm{~B}$, com o terceiro menor valor de biomassa vegetal aérea por unidade de superfície, encontra-se coberta por cerrado stricto sensu aberto. As árvores aqui apresentam menores dimensões, porém são mais numerosas do que nas áreas anteriores. A AB é de $2,7 \mathrm{~m}^{2} /$ ha, a distância média entre árvores é de 11,2 metros e o peso médio por indivíduo é de $85,79 \mathrm{~kg}$, sendo que foram contabilizadas 79,9 árvores/ha. O valor de biomassa é de 6,86 T/ha e o de retroespalhamento médio na imagem de radar que corresponde a esta área é -11,27 dB. Luckman et al. (1997) encontraram o valor de biomassa 8 T/ha em uma área de regeneração na floresta Amazônica. O valor de retroespalhamento que os autores determinaram na imagem para essa área é -11,5 dB. 
TABELA 9. Coordenadas centrais das áreas amostrais, biomassa e valores de retroespalhamento na imagem JERS-1.

\begin{tabular}{|c|c|c|c|c|c|c|c|}
\hline Área & Nome da área & $\begin{array}{c}\text { Coordenadas } \\
\text { UTM } 22 \mathrm{~S}\end{array}$ & $\begin{array}{c}\text { Biomassa } \\
\text { (T/ha) }\end{array}$ & $\begin{array}{l}\text { Retroespalhamento } \\
\text { (dB) }\end{array}$ & $\begin{array}{l}\text { Distância } \\
\text { média (m) }\end{array}$ & $\begin{array}{l}\text { AB média } \\
\left(\mathrm{m}^{2} / \mathrm{ha}\right)\end{array}$ & $\begin{array}{c}\text { Peso médio } \\
\text { das árvores } \\
\quad(\mathrm{kg})\end{array}$ \\
\hline $1 \mathrm{~B}$ & P-Arv2 & $\begin{array}{l}0600434 \\
7506980\end{array}$ & 1,7 & $-14,87$ & 67,0 & 0,55 & 240,62 \\
\hline $2 \mathrm{~B}$ & PasArv & $\begin{array}{l}0601024 \\
7506601\end{array}$ & 5,0 & $-11,36$ & 18,82 & 1,7 & 178,54 \\
\hline $3 \mathrm{~B}$ & CerradoAberto08 & $\begin{array}{l}0595500 \\
7506500\end{array}$ & 6,9 & $-11,27$ & 11,2 & 2,7 & 85,79 \\
\hline $4 \mathrm{~B}$ & Pto52 & $\begin{array}{l}0599802 \\
7505514\end{array}$ & 33,4 & $-10,40$ & 3,3 & 11,9 & 37,58 \\
\hline $5 \mathrm{~B}$ & Pto42 & $\begin{array}{l}0595600 \\
7506100\end{array}$ & 57,7 & $-10,51$ & 3,3 & 20,11 & 63,39 \\
\hline $6 \mathrm{~B}$ & Faz. Três Irmãos-2 & $\begin{array}{l}0603184 \\
7509365\end{array}$ & 62,7 & $-8,71$ & 3,2 & 17,6 & 63,72 \\
\hline $7 \mathrm{~B}$ & GK4 & $\begin{array}{l}0597750 \\
7505555\end{array}$ & 72,2 & $-8,15$ & 3,55 & 20,11 & 91,05 \\
\hline $8 \mathrm{~B}$ & Faz. Três Irmãos-1 & $\begin{array}{l}0603304 \\
7508911\end{array}$ & 105,1 & $-7,44$ & 2,23 & 27,3 & 52,40 \\
\hline $9 \mathrm{~B}$ & GK-3 beira do rio & $\begin{array}{l}0597465 \\
7506950\end{array}$ & 119,91 & $-7,92$ & 3,13 & 86,9 & 110,08 \\
\hline $10 \mathrm{~B}$ & GK2 & $\begin{array}{l}0597753 \\
7506443\end{array}$ & 124,36 & $-6,67$ & 3,55 & 36,9 & 126,85 \\
\hline
\end{tabular}


A área 4B é a seguinte em ordem crescente de valores de biomassa florestal aérea por unidade de área. Corresponde a uma área de ecótono entre cerradão e floresta estacional semi-decidual, de acordo com o levantamento florístico realizado por Durigan (1999). Este tipo de vegetação permitiria esperar valores de biomassa vegetal significativamente maiores aos que se observam nas áreas cobertas tanto pelo cerrado quanto pelo cerradão (BATALHA et al. 2001). No entanto, essa situação não foi a encontrada nessa área. Provavelmente, isso é resultado da retirada total da vegetação arbórea, há aproximadamente 20 anos, sendo que atualmente apresenta uma cobertura florestal em processo de regeneração. Muitas árvores apresentam rebrote desde a parte inferior do caule (Figura 16), pois foi a porção que permaneceu no terreno após a retirada do fuste, que é a porção com valor comercial. Das 80 árvores amostradas nesta área, $17(21,25 \%)$ apresentaram este fenômeno de rebrote múltiplo axilar (Tabela 6). Esta área encontra-se comunicada com outras destinadas à pastagem, por isso o gado a invade continuamente, dificultando assim a regeneração da vegetação florestal. $\mathrm{O}$ valor de $\mathrm{AB}$ nessa área é de $11,9 \mathrm{~m}^{2} /$ ha, enquanto o peso médio das árvores medidas é de $37,58 \mathrm{~kg}$ e a distância média entre os indivíduos é de 3,3 metros. Essa proximidade determina a ocorrência de um grande número de árvores por hectare, 889,4. Provavelmente a vegetação nessa área está longe de ter atingido o clímax determinado pelo solo. Supõe-se que a quantidade de biomassa por unidade de área nesse local aumente com o decorrer do tempo. Essa seria a expectativa, caso nenhum outro fator (como a ação do gado) impedisse o avanço do processo sucessional. A biomassa determinada nessa área é 33,43 T/ha e o valor de retroespalhamento médio é $-10,40 \mathrm{~dB}$. Austin et al. (2003), trabalhando em uma área coberta por eucaliptos na Austrália, com 29,5 T/ha de biomassa, determinaram um valor de retroespalhamento de $-10,9 \mathrm{~dB}$, em imagens produzidas pelo mesmo sensor. 
$\mathrm{A}$ área 5B se encontra coberta por cerradão, com acúmulo de serapilheira no solo Este é um indício de que o fogo provavelmente não penetra nesta área, e se o faz, esse evento não se repete freqüentemente. As árvores encontram-se a uma distância média similar às árvores da última área descrita, isto é, 3,3 metros e devido a isto o número de indivíduos por hectare também é similar, embora um pouco maior: 910,7 árvores/ha. $\mathrm{A} \mathrm{AB}$ é de $20,11 \mathrm{~m}^{2} /$ ha, enquanto que a biomassa média por indivíduo é de $63,39 \mathrm{~kg}$ e a biomassa por unidade de área é de 57,72 T/ha. O valor de retroespalhamento médio nesta área é de $-10,51 \mathrm{~dB}$.

Todas as áreas descritas até aqui estão localizadas dentro da Fazenda Alvorada de Bragança. Diferentemente, as áreas $6 \mathrm{~B}$ e $8 \mathrm{~B}$, estão dentro de um fragmento geograficamente separado das anteriores. Esse é o único fragmento amostrado nesse trabalho que se encontra dentro da Fazenda Três Irmãos. A vegetação arbórea que cobre esse fragmento foi submetida a corte raso há aproximadamente 30 anos, mas desde então tem sido protegida com cercas que impedem a entrada de gado. Por este motivo, o avanço da regeneração da vegetação natural é evidente e o fragmento está coberto por cerradão em bom estado de conservação, conformando uma fisionomia tipicamente florestal. Dentro do fragmento foram escolhidas duas áreas amostrais relativamente homogêneas.

A área 6B é a mais próxima da borda. Ali os indivíduos estão separados 3,2 metros um do outro, determinando a existência de 983 árvores/ha. A AB é 17,6 m²/ha e o peso médio por árvore é $63,72 \mathrm{~kg}$. A quantidade de biomassa vegetal aérea atinge o valor médio de 62,67 T/ha e o retroespalhamento médio nesta área é $-8,71 \mathrm{~dB}$. Luckman et al. (1997) encontraram os valores de retroespalhamento $-8,1$ e $-8,4 \mathrm{~dB}$ em duas áreas com $62 \mathrm{~T} /$ ha de biomassa aérea. 
A área 8B, que está dentro do mesmo fragmento de cerradão, encontra-se mais afastada do limite da fisionomia florestal com o pasto e, devido a isto, provavelmente é menos influenciada pelo efeito de borda. Os indivíduos incluídos na amostragem apresentam um peso médio de 52,4 kg, e estão distanciados 2,23 metros em média uns dos outros. Esta é a área amostrada onde as árvores encontravam-se mais próximas e onde a densidade de indivíduos é maior, 2006 árvores/ha. A AB é de $27,34 \mathrm{~m}^{2} /$ ha. O valor médio de biomassa encontrado aqui é de $105,14 \mathrm{~T} / \mathrm{ha}$ e o valor médio de retroespalhamento é de $-7,44 \mathrm{~dB}$.

Poucas informações estão disponíveis sobre o histórico de uso do solo nas fazendas estudadas. Na carta topográfica Campos Novos Paulista (IBGE, 1975), toda a área da Fazenda Alvorada de Bragança, que inclui todas as áreas amostradas com exceção das duas mencionadas por último, aparece descrita como coberta por pastagem. A única exceção está constituída por uma faixa localizada ao longo de uma drenagem, se distribui aproximadamente de Norte a Sul. Na legenda da carta, esta área está descrita como "mata, cerrado, macega, floresta ou caatinga". Embora esta descrição seja excessivamente ampla e geral, pode-se inferir que a vegetação florestal mais antiga da área esteja localizada exatamente dentro dessa faixa. Também parece lógico admitir que a regeneração do cerrado stricto sensu e do cerradão nas áreas vizinhas tenha sido feita, pelo menos em parte, a partir de propágulos provenientes da vegetação presente nesta faixa. Por estes motivos, foram definidas três áreas de amostragem na região (áreas 7B, 9B e 10B). A primeira dessas, identificada como área 7B, está em uma encosta com alta declividade, à beira da drenagem mencionada. O solo encontra-se coberto por vegetação que conforma uma fisionomia do tipo cerradão, com algumas árvores emergentes. Há evidências de presença de fogo no passado, identificado por restos de carvão na cortiça de alguns indivíduos arbóreos. O 
ambiente no sub-bosque é úmido e existem touceiras de bambu e numerosas bromélias de chão. A AB desta área é $20,11 \mathrm{~m}^{2} /$ ha. O peso das árvores amostradas nesta área tem um valor médio de $91,05 \mathrm{~kg}$, e estão separados por uma distância de 3,55 metros em média. Foi determinado que existem 793,4 árvores/ha. Esta área apresenta o valor médio de biomassa florestal aérea de 72,24 toneladas por hectare. $\mathrm{O}$ valor de retroespalhamento médio determinado é $-8,15$ dB. Luckman et al. (1997), trabalhando em uma área com $75 \mathrm{~T} / \mathrm{ha}$ de biomassa lenhosa aérea, encontraram o valor de retroespalhamento $-7,7 \mathrm{~dB}$.

A área 9B, também localizada dentro dessa faixa que contorna a drenagem, apresenta $\mathrm{AB}$ de $86,9 \mathrm{~m}^{2} /$ ha. O peso médio das árvores se distribui em torno de $110,08 \mathrm{~kg}$ e os indivíduos amostrados estão distanciados 3,13 m. em média, encontrando-se 1016,6 árvores/ha. O valor médio de biomassa determinado nesta área é de 119,91 T/ha e o de retroespalhamento médio é -7,92 dB.

A área 10B é a terceira, e última, amostrada dentro da faixa de vegetação à beira da drenagem. Essa é a que apresenta a maior quantidade de biomassa dentre todas as áreas amostradas no presente trabalho, isto é, 124,36 T/ha, confirmando as previsões baseadas na antiguidade da vegetação na área. $\mathrm{A} A B$ nesta área é de $36,9 \mathrm{~m}^{2} / \mathrm{ha}$. As árvores pesam 126,85 kg em média e estão separadas por uma distância média de 3,55 metros, determinando a existência de 980,4 árvores/ha. $\mathrm{O}$ valor de retroespalhamento médio determinado nesta área é de -6,67dB. Sano et al. (2001) encontraram o mesmo valor de retroespalhamento, $-6,67 \mathrm{~dB}$, em uma área de mata ciliar no planalto central. Estes autores não quantificaram a biomassa dessa área. É possível que o fato de estar localizada em uma área próxima a um curso de água, e devido a isso não submetida a déficit hídrico em nenhum período do ano, seja responsável pelo acúmulo de biomassa lenhosa aérea, cujo valor médio, como já foi 
mencionado é 124,36 T/ha., o maior das áreas amostradas durante este trabalho. Outro elemento que deve ser considerado é a declividade, que pode possibilitar maior exposição à radiação solar, facilitando maiores taxas de fotossíntese do que nas áreas sobre relevo plano. Além disso, deve-se ter em vista que, provavelmente, esta seja a área com vegetação nativa mais antiga dentro da região estudada.

A relação entre os valores de biomassa, coletados no campo, e os de retroespalhamento, obtidos na imagem JERS-1, foi verificada pelo teste de correlação de Pearson com auxílio do aplicativo Statistica (STARSOFT, 1996).

A análise de correlação requer que a distribuição dos dados de ambas variáveis consideradas seja normal (SOKAL; ROLF, 1987). Foi assumido que a distribuição dos valores dos pixels dentro das áreas amostradas na imagem de radar é normal. Com o aplicativo Statistica, foi testado se a distribuição dos valores médios de biomassa lenhosa aérea e $\mathrm{AB}$ amostrados podem ser consideradas normais. Os resultados indicam que não pode ser afirmado que as distribuições não sejam normais, por isso as correlações podem ser calculadas.

A Figura 24 mostra a curva que relaciona os valores dos dados coletados no campo de biomassa lenhosa aérea com os valores de retroespalhamento em $\mathrm{dB}$ para as áreas correspondentes na imagem JERS-1. A Tabela 10 mostra os valores dos desvio padrão da variável retroespalhamento nos dados amostrados. 


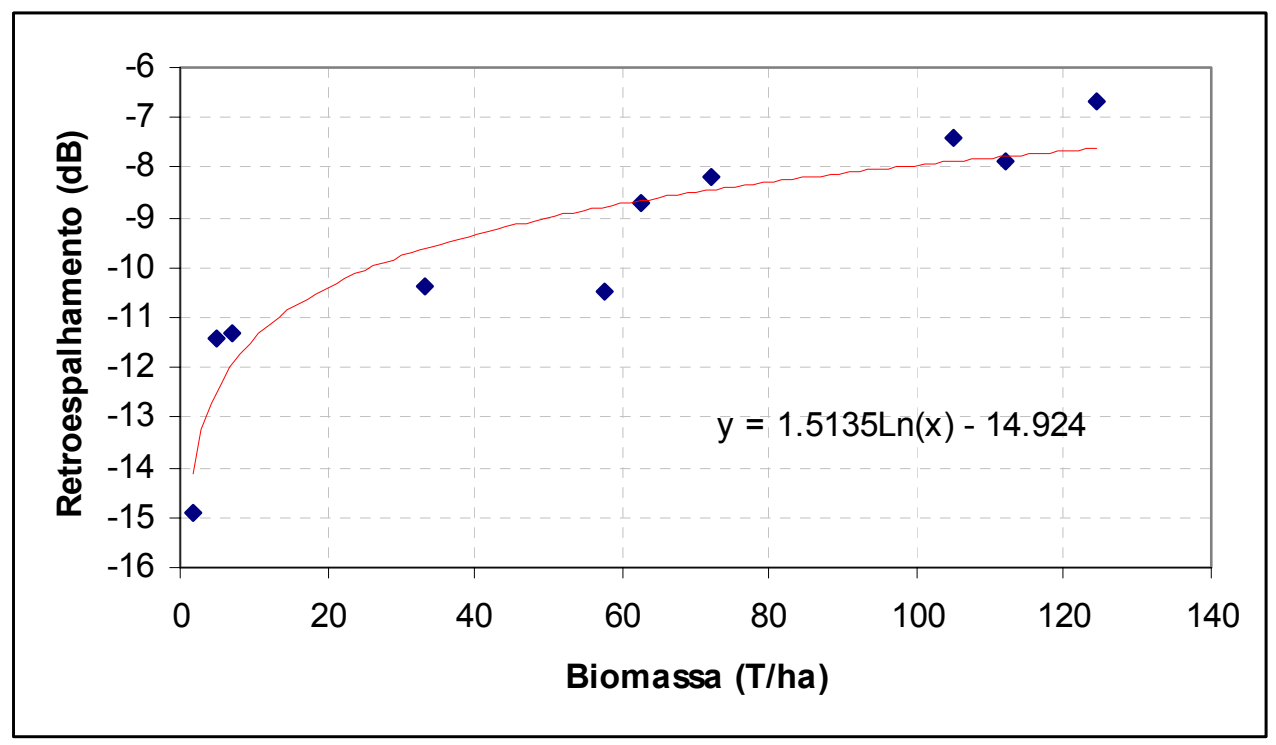

Figura 24. Relação entre os valores médios das amostras de biomassa lenhosa aérea e os valores de retroespalhamento em unidades de decibéis $(\mathrm{dB})$ da imagem JERS-1. A curva foi ajustada aos dados pelo método dos mínimos quadrados.

TABELA 10. Desvio padrão do retroespalhamento $\sigma(\mathrm{dB})$ para as dez áreas amostradas.

\begin{tabular}{cc}
\hline Área & $\begin{array}{c}\text { Desvio padrão do } \\
\text { retroespalhamento } \sigma\end{array}$ \\
\hline 1B & 0,8468 \\
2B & 0,5740 \\
3B & 0,686 \\
4B & 0,5904 \\
5B & 0,4997 \\
6B & 0,5077 \\
7B & 0,4900 \\
8B & 0,5118 \\
9B & 0,7240 \\
10B & 0,4770 \\
\hline
\end{tabular}

A Equação 7 define esta curva que relaciona ambas variáveis:

Retroespalhamento $(\mathrm{dB})=1,5135 \operatorname{Ln}($ biomassa $(\mathrm{T} / \mathrm{ha}))-14,.924(7)$ 
Esta equação é similar à encontrada por Santos et al. (2002) e Santos et al. (2000).

A análise da curva sugere que incrementos nos valores de biomassa vegetal correspondem a incrementos decrescentes nos valores de retroespalhamento. Observa-se uma tendência da curva à estabilidade, à medida que aumentam os valores da variável biomassa lenhosa aérea. Porém, a estabilidade da curva não foi atingida com os dados disponíveis no presente estudo.

O comportamento de ambas variáveis permite sugerir a utilidade das imagens de radar na banda L, especificamente do sensor imageador de microondas do satélite JERS-1, para a estimativa, ou até possivelmente, para a quantificação de biomassa lenhosa aérea em áreas de cerrado e cerradão.

As microondas interagem com os troncos das árvores. Assim, o sinal de retorno que é registrado pelo sensor está relacionado à quantidade de biomassa lenhosa em pé. No entanto, é importante salientar que o sinal está influenciado tanto pelas árvores vivas quanto pelas mortas.

Outra variável que influencia o retroespalhamento das microondas é o conteúdo hídrico dos alvos imageados. Objetos secos aparecem mais escuros do que objetos úmidos de formas e dimensões similares. Desta forma, apesar das árvores em pé (vivas e mortas) contribuírem no sinal que é registrado pelo sensor, a diferença no teor de água pode ser responsável por variações na resposta dos dois grupos: o dos indivíduos vivos e o dos mortos em pé. Assim, é necessário considerar que os dados derivados a partir das imagens de radar integram o sinal da biomassa viva e morta em pé (AUSTIN et al. 2002).

A tendência à estabilidade da curva, à medida que se incrementam os valores de biomassa aérea, poderia ser responsável por uma diminuição da eficácia desta ferramenta em condições florestais muito densas, como no caso de florestas tropicais 
pluviais ou mesmo em florestas implantadas. Nas primeiras, os valores de biomassa podem superar o valor de $400 \mathrm{~T} / \mathrm{ha}$.

Numerosos trabalhos mencionam diferentes valores de limiares de biomassa lenhosa aérea aos quais se estabiliza a resposta das microondas em sistemas SAR na banda L. Assim, Imhoff (1995) (apud SANTOS et al. 2002) propõe um limiar de $40 \mathrm{~T} / \mathrm{ha}$. Luckman et al. (1997); Luckman et al. (1998) e Santos et al. (2000) propõem um valor superior de 60 T/ha. Já Araujo et al. (1999), Kasischke et al. (1997) e Sun et al. (2002) sugerem um valor de $100 \mathrm{~T} / \mathrm{ha}$. Por outro lado Ranson et al. (1997) propõem $150 \mathrm{~T} / \mathrm{ha}$. enquanto Austin et al. (2002) afirmam que conseguiram estimar valores de até $700 \mathrm{~T} / \mathrm{ha}$. trabalhando com imagens JERS-1 em uma floresta de eucaliptos na Austrália.

Apesar da grande amplitude dos valores máximos de biomassa florestal aérea sugeridos pelos diferentes autores como passíveis de serem estimados por meio de imagens de radar na banda L, há consenso na existência de um valor superior a partir do qual não seria mais possível estimar este parâmetro. Com base nos trabalhos disponíveis, é evidente que as imagens SAR na banda L são adequadas para estimar biomassa florestal aérea em ecossistemas com valores de biomassa médios, similares aos normalmente encontrados em áreas cobertas por cerrado e cerradão.

No presente trabalho, a curva não atingiu a estabilidade. No entanto, os incrementos dos valores de retroespalhamento nas áreas com maior quantidade de biomassa tornaram-se cada vez menores.

Santos et al. (2002) também utilizaram imagens de radar JERS-1 na quantificação de biomassa vegetal aérea de cerradão e floresta Amazônica, em uma área de contato entre estas formações vegetais. Estes autores encontraram valores de biomassa que superavam grandemente os do limite máximo do presente trabalho. Embora o tipo de 
cerrado com que estes autores trabalharam seja muito diferente do estudado no presente trabalho, eles encontraram uma relação similar à apresentada aqui.

Em uma análise qualitativa, Sano et al. (2001) utilizaram imagens do mesmo satélite para a separação de fisionomias vegetais de cerrado na região central de domínio deste bioma. Esses autores encontraram valores de retroespalhamento $(\sigma)$ de $-6,67 \mathrm{~dB}$ para florestas de galeria. No presente trabalho, os valores de $\sigma$ para o cerradão com alta quantidade de biomassa variaram em torno do mesmo valor $\sigma=-6,67$. Sano et al. (2001), também encontraram valores de $\sigma=-13,6 \mathrm{~dB}$ nas áreas de cerrado stricto sensu mais aberto, enquanto que nesse trabalho os valores de retroespalhamento em áreas dessa fisionomia oscilaram entre $-11,27$ e $-14,87 \mathrm{~dB}$.

O radar é extremamente sensível à textura, devido à sua natureza e geometria de observação. Assim, diferenças de rugosidade são salientadas nas imagens geradas por estes sensores. Áreas com superfícies lisas e homogêneas, tal como corpos de água, aparecem uniformes e escuras. Isso ocorre porque a maior parte do sinal emitido pelo satélite é refletida de forma especular, enquanto que uma pequena porção volta na direção do satélite. À medida que aumenta a rugosidade (por exemplo, devido a ondas na superfície de um corpo de água), a proporção do sinal retroespalhado em direção ao sensor aumenta.

Em áreas cobertas por vegetação, o comportamento da radiação é similar. Áreas relativamente homogêneas e lisas, tais como pastagem, aparecem homogêneas e obscuras. Em contraste, áreas ocupadas por florestas multi-específicas, com indivíduos de diferentes idades, diâmetros e alturas, com clareiras e árvores emergentes, aparecem nas imagens de radar em formas muito heterogêneas. Assim, é esperado que uma imagem de floresta natural esteja formada por uma ampla gama de 
valores, representando a intensidade da energia retroespalhada pelos diferentes alvos que a compõem.

A vegetação do cerrado stricto sensu tipicamente não forma dosséis. Por isso, constitui um claro exemplo de formação vegetal com alta rugosidade. As copas das árvores não estão em contato entre si e os indivíduos de diferentes alturas determinam uma superfície rugosa. Essa característica torna o sinal do radar muito influenciado pela geometria dos elementos florestais das diferentes fisionomias do cerrado.

Para verificar a influência da distância entre as árvores sobre o sinal de radar foi feito um teste de correlação de Pearson entre os valores amostrados dessas duas variáveis. Para tanto, foram considerados os valores médios de distância entre as árvores de cada área amostrada e os de retroespalhamento extraídos da imagem de radar para as regiões correspondentes. Os valores utilizados estão apresentados na Tabela 11.

TABELA 11. Valores de retroespalhamento $(\mathrm{dB})$ e de distância média entre árvores nas áreas amostradas.

\begin{tabular}{|c|c|c|}
\hline Área & Retroespalhamento (dB) & Distância média (m) \\
\hline 1B & $-14,9$ & 38,3 \\
\hline $2 \mathrm{~B}$ & $-11,4$ & 18,8 \\
\hline $3 B$ & $-11,3$ & 11,2 \\
\hline $4 \mathrm{~B}$ & $-10,4$ & 3,3 \\
\hline $5 B$ & $-10,5$ & 3,3 \\
\hline $6 \mathrm{~B}$ & $-8,7$ & 3,2 \\
\hline $7 \mathrm{~B}$ & $-8,2$ & 3,5 \\
\hline $8 \mathrm{~B}$ & $-7,4$ & 2,2 \\
\hline $9 \mathrm{~B}$ & $-7,9$ & 3,1 \\
\hline 10B & $-6,7$ & 3,5 \\
\hline
\end{tabular}

Foi encontrada uma correlação linear negativa entre essas variáveis $(r=-0,87$; $\mathrm{p}=0,00093$ ), como mostra a Figura 25. 
Com base nos dados disponíveis no presente trabalho, pode-se afirmar que existe uma tendência à diminuição dos valores de retroespalhamento à medida que aumenta a distância entre as árvores. Esse resultado é esperado, uma vez que o aumento na distância entre as árvores provoca a diminuição no número dos indivíduos por unidade de área. Geralmente, tal diminuição coincide com o decréscimo da quantidade de biomassa por unidade de área.

A equação que explica a relação entre os valores de ambas variáveis nas amostras disponíveis é do tipo exponencial e é representada por $\mathrm{Y}=0,0732 \mathrm{e}^{-0,3428 \mathrm{x}}$

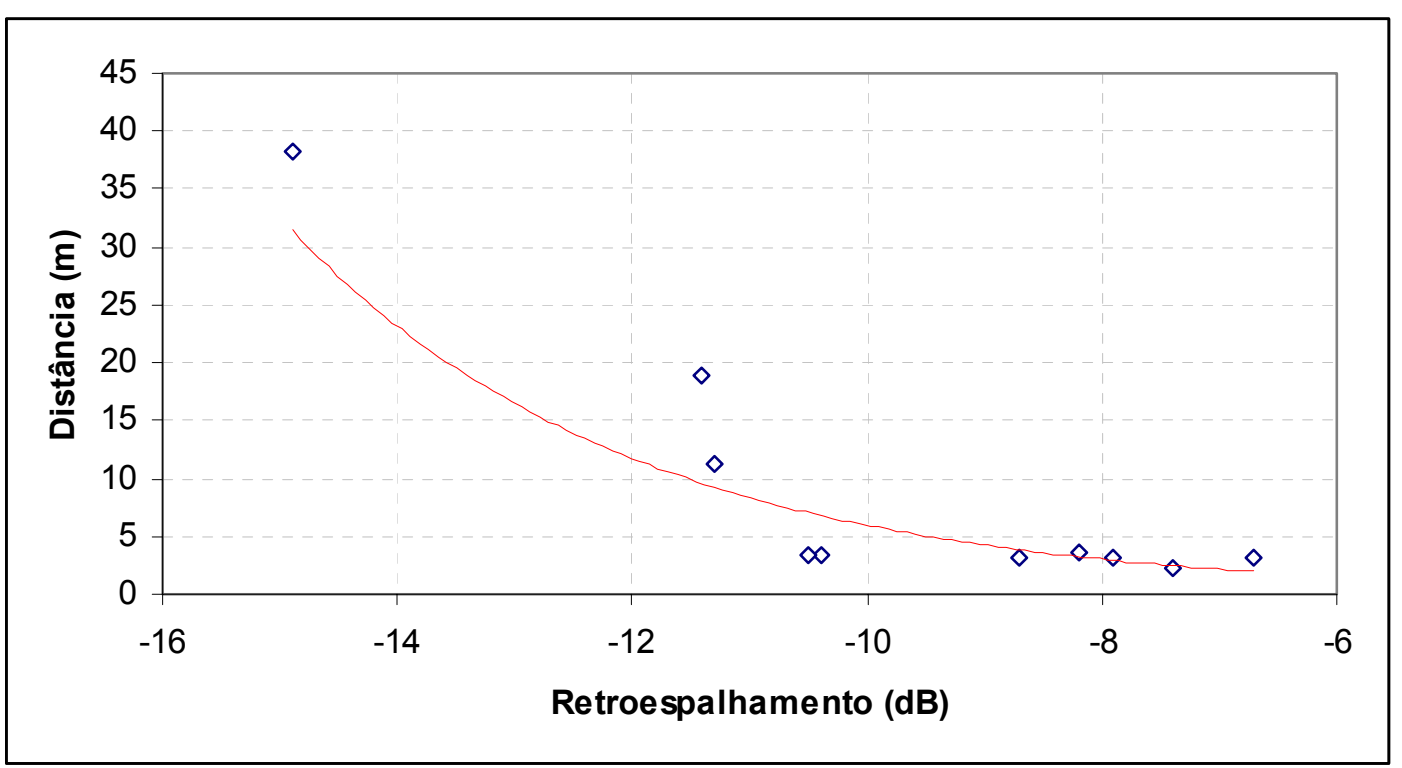

Figura 25. Relação entre os valores de distância entre as árvores (m) de cada amostra e os valores de retroespalhamento (dB) da imagem JERS-1.

Os valores de distância apresentam maior amplitude nas áreas em que as árvores estão mais distanciadas entre si. A distância máxima absoluta encontrada, 109 metros, foi medida na área 1B. Essa área também apresentou o maior valor médio de distância entre as árvores, 38,29 metros.

O menor valor médio de distância, 2,23 metros, foi encontrado na área 8B, a mesma área que apresentou o menor valor absoluto, 0,2 metros. 
O Diâmetro na Base (DB) foi medido em cada indivíduo na base do fuste no nível do solo. Esse é outro parâmetro freqüentemente utilizado para descrever comunidades vegetais florestais (MUELLER-DOMBOIS; ELLEMBERG, 1974; MATTEUCCI; COLMA, 1982), principalmente quando as árvores apresentam mais de um fuste.

A vegetação florestal do cerrado possui a característica de apresentar múltiplos talhos desde a base. Geralmente isso é devido à presença de gemas axilares latentes que se tornam ativas após a retirada da parte aérea (RIZZINI, 1979). A eliminação da parte aérea das árvores e arbustos do cerrado e cerradão é um evento comum, que pode ser atribuído ao fogo ou à ação antrópica. A vegetação do bioma cerrado tem evoluído no sentido de adaptar-se a esses eventos, através do brotamento das gemas axilares após a eliminação da parte aérea. Assim, é comum encontrar a presença de árvores e arbustos nos quais não há um fuste principal, mas sim vários e de dimensões similares. Esse fenômeno pode ser observado na Figura 16.

A fim de solucionar a dificuldade de determinar um valor de DB nesses casos, essa variável é substituída pelo DB equivalente, o qual leva em consideração a somatória da área dos caules. Portanto, o procedimento para determinar o DB equivalente em indivíduos florestais consiste na medição do Perímetro à Altura do Peito (PAP) de cada caule individual. Com esses dados, calcula-se a Área à Altura do Peito (AAP) de cada caule. A seguir, somam-se as áreas correspondentes a todos os caules de cada indivíduo, obtendo-se a AAP da árvore. Finalmente calcula-se o DB de uma circunferência de área igual à AAP calculada. Assim obtêm-se um DB equivalente que na verdade não existe fisicamente mas que representa o DB que teria uma árvore com um único talo com área à altura do peito igual à do indivíduo em questão. Essa metodologia permite padronizar a determinação desta variável, considerando o volume de madeira da árvore. 
A área de estudo onde foi realizado o presente trabalho inclui vários indivíduos que apresentam esse fenômeno de rebrote múltiplo axilar desde a base (Tabela 6), provavelmente devido à vegetação ter sido submetida a corte raso no passado. Por este motivo, o DB foi calculado pela metodologia exposta acima para os indivíduos que apresentam esse fenômeno e, a partir desses valores, foi computada a área basal média por hectare $\mathrm{AB} / \mathrm{ha}$.

A relação entre a $\mathrm{AB}$ e o retroespalhamento foi verificada por meio do teste de correlação linear de Pearson com auxílio do aplicativo Statistica (STARSOFT, 1996). Com alfa $=0,09$ não foi encontrada correlação entre essas duas variáveis $(\mathrm{r}=0,61$; $\mathrm{p}=0,058)$.

O gráfico que representa a dispersão entre $\mathrm{AB}$ e retroespalhamento está representado na Figura 26.

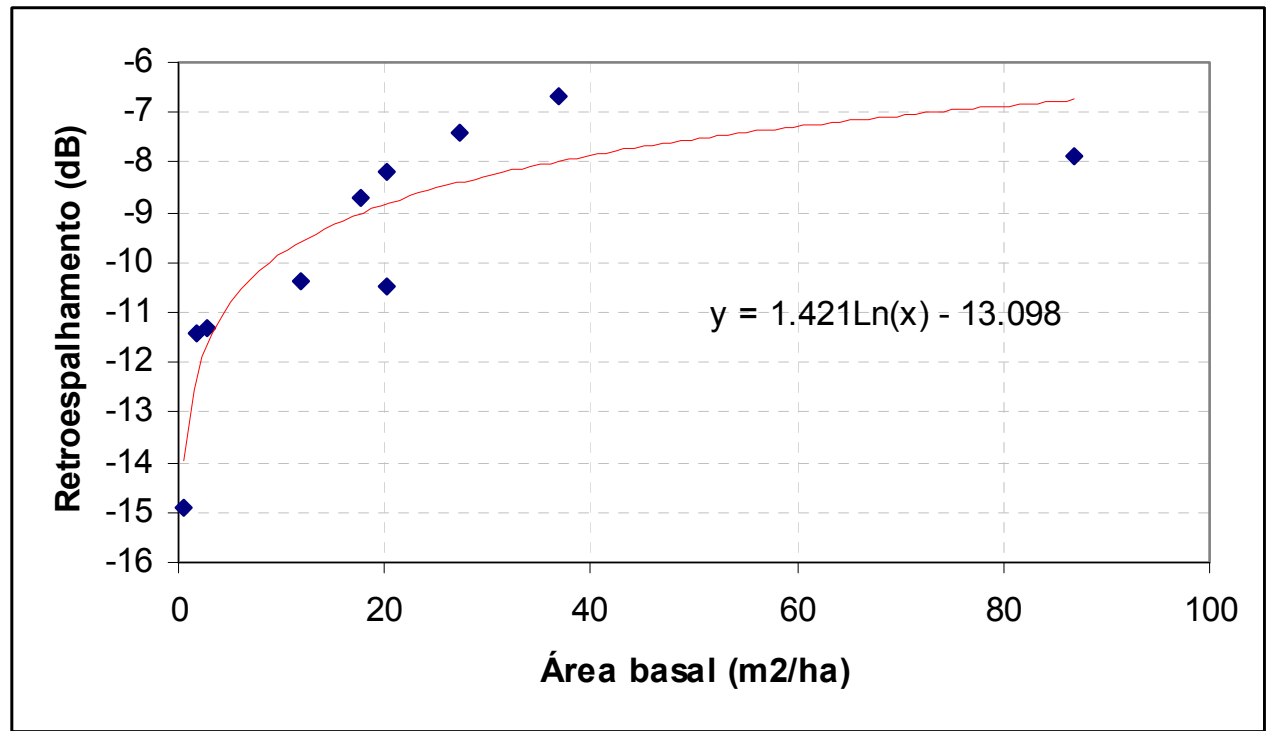

Figura 26. Relação entre os valores médios de $\mathrm{AB} /$ ha e de retroespalhamento. A curva foi ajustada aos dados pelo método dos mínimos quadrados.

90\% dos dados que sintetizam as informações de $\mathrm{AB}$ estão incluídos no intervalo de zero a $40 \mathrm{~m}^{2} /$ ha, enquanto somente $10 \%$ dos dados superam este limiar máximo. Esses $10 \%$ encontram-se representados por um único valor $\left(86,9 \mathrm{~m}^{2} / \mathrm{ha}\right)$, resultado da 
média aritmética de 80 árvores da área 9B. A curva que se ajusta aos dados disponíveis sugere a existência de uma relação do tipo logarítmica entre as variáveis retroespalhamento $(\mathrm{dB})$ e $\mathrm{AB}(\mathrm{m} 2 / \mathrm{ha})$. Esse comportamento fica definido pela Equação 8.

Retroespalhamento=1,421* Ln (Área basal média $\left[\mathrm{m}^{2} / \mathrm{ha}\right]-13,098(8)$

O ponto da curva determinado pelo par de valores da área 9B pode ser considerado um outlyer. A distância entre este ponto e o anterior no eixo das abscissa (AB) é de 50 unidades $\left(\mathrm{m}^{2}\right)$, enquanto os outros $90 \%$ dos valores se distribuem em menos de 40 $\mathrm{m}^{2}$. Os valores que assumem ambas variáveis no ponto 9B são confiáveis, pois derivam de médias de 80 árvores e de 16 pixels. No entanto, carece-se de informações acerca do comportamento das variáveis no intervalo entre o ponto $9 \mathrm{~B}$ e o $10 \mathrm{~B}$, imediatamente anterior. A falta de dados de $\mathrm{AB}$ no intervalo mencionado é devida a que a verificação da relação existente entre a $A B$ e os valores de retroespalhamento não é o objetivo principal deste trabalho. Por este motivo a estratégia de amostragem não levou em consideração a coleta de dados no intervalo mencionado.

Os valores de retroespalhamento registrados nas imagens JERS-1 parecem úteis para estimar $\mathrm{AB}$ de espécies lenhosas em áreas de cerrado e cerradão. No entanto, com base nestes dados, somente é possível fazer inferências dos valores que a variável $\mathrm{AB}$ assumiria a partir de valores de retroespalhamento no intervalo $0-40 \mathrm{~m} 2 / \mathrm{ha}$.

Se esse ponto fosse eliminado do conjunto de dados, a equação ficaria definida pelos nove pontos restantes segundo a Equação 9.

$$
\text { Retroespalhamento=1,5774 } \operatorname{Ln}(\mathrm{AB})-13,304 \text { (9) }
$$

A curva que a representa está graficada na Figura 27. 


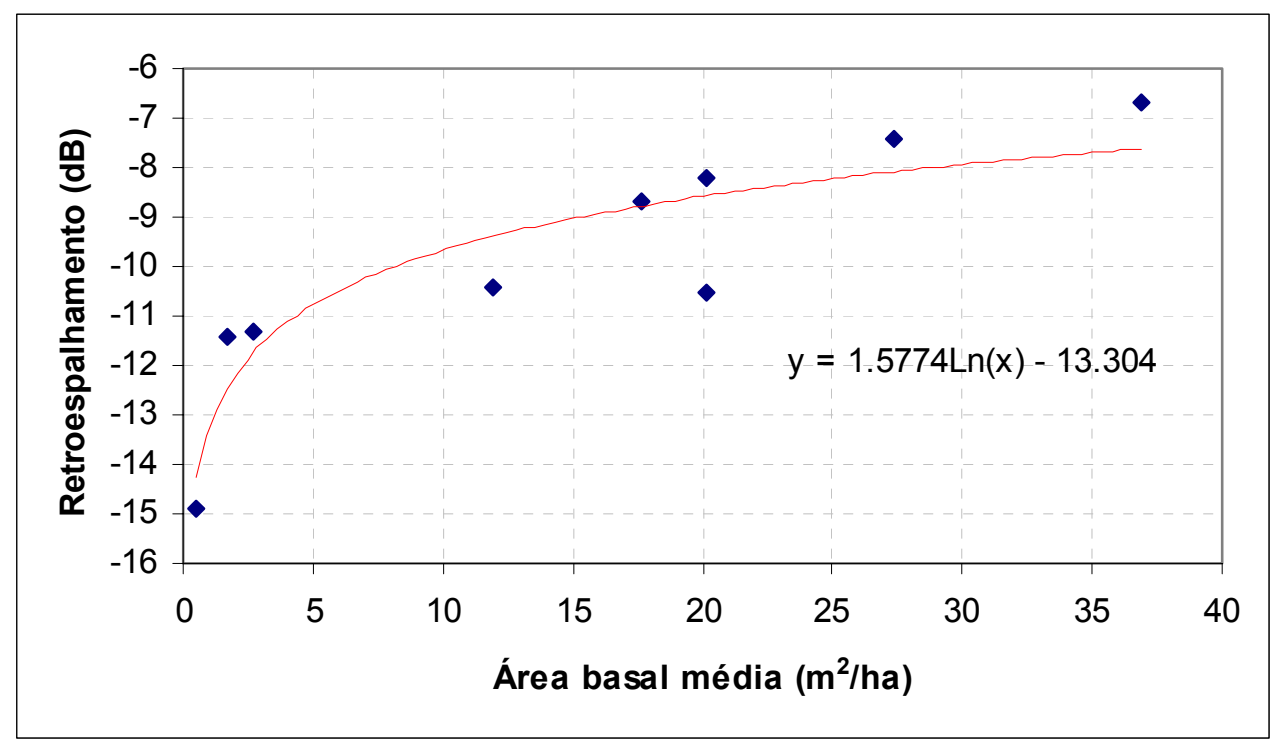

Figura 27. Relação entre os valores médios de $\mathrm{AB} /$ ha e de retroespalhamento $(\mathrm{dB})$.

Esta curva parece representar o comportamento de ambas variáveis com maior grau de certeza que a anterior, pois a distribuição dos valores é mais homogênea ao longo do intervalo de $\mathrm{AB}$ considerado. No entanto considera-se conveniente considerar o décimo par de valores, correspondente à área 9B, pois eles foram obtidos de maneira confiável e indicam uma tendência da curva à estabilidade à medida que se incrementam valores de $\mathrm{AB}$.

A radiação emitida pelo radar do satélite na faixa espectral de $23,5 \mathrm{~cm}$. interage com objetos de dimensões similares na superfície terrestre. Assim, árvores com DB de 20 $\mathrm{cm}$ ou maiores conseguem sensibilizar o sensor do radar. No entanto, as árvores com múltiplos talos freqüentemente apresentam uma diminuição do DB de cada um deles individualmente, embora o DB-equivalente seja similar a árvores de altura similar. Portanto, é possível que o sinal de radar na banda L retroespalhado por árvores com múltiplos fustes e DB-equivalente superior a $20 \mathrm{~cm}$. não seja o mesmo ao retroespalhado por indivíduos com um único fuste com o mesmo DB. Provavelmente, o sensor não consegue captar os caules mais finos desses indivíduos e, por esse 
motivo, subestima a biomassa da árvore. A ausência de relação linear entre DB e o sinal de retroespalhamento pode ser devida à grande variação no diâmetro das árvores. Assim, algumas poderiam ser totalmente captadas pelo sensor, enquanto outras poderiam ter somente alguns de seus talos registrados, provavelmente os mais grossos.

Seriam necessários estudos mais aprofundados para determinar se há ou não uma relação entre ambas variáveis.

Os inconvenientes que resultaram nos resultados obtidos na comparação dos valores de IAF com os de IVDN e IVR impossibilitaram comprovar o objetivo geral relativo à complementaridade dos dados ópticos e de radar na estimativa da biomassa vegetal. Como foi mencionado anteriormente, o dispositivo utilizado para realizar as determinações de IAF nas áreas abertas, onde predomina o estrato herbáceo, provavelmente seja inadequado para essas medições nas condições encontradas na área de estudo.

O estrato herbáceo do cerrado é muito sensível à ação antrópica. Os remanescentes de cerrado, onde o presente trabalho foi desenvolvido, tiveram seu estado de conservação avaliado mediante levantamentos do componente lenhoso. $\mathrm{O}$ estrato herbáceo não foi considerado para esta avaliação. No entanto, este último é o que sofre maior impacto pela ação do gado que continuamente invade os fragmentos, pisoteando e consumindo as plantas herbáceas. Assim, uma fonte de erro nas comparações pode ter sido a ação do gado no período transcorrido entre a aquisição da imagem e os trabalhos de campo.

Vários trabalhos na literatura de sensoriamento remoto salientam a relação entre IAF e os índices de vegetação IVDN e IVR. Embora isto não tenha sido comprovado no presente trabalho, considera-se que há consenso geral sobre o tipo de relação 
existente entre ambas variáveis. O segundo objetivo específico foi atingido, isto é, a determinação de uma equação que caracterize a relação existente entre a biomassa lenhosa aérea e o retroespalhamento em imagens de radar da banda L. Deste modo, o objetivo geral pode ser considerado também atingido, pelo menos parcialmente, pela junção do consenso mencionado das imagens ópticas e os IV e dos resultados obtidos com imagens de radar. 


\section{6 - Conclusões}

Com base nos dados coletados no presente trabalho, não foi possível estabelecer correlações entre os valores IAF e os dos índices IVDN e IVR. Isso foi conseqüência de limitações da metodologia de amostragem no campo. O sensor LAI-2000 é adequado para determinações de IAF em dosséis vegetais homogêneos. Contudo, as áreas escolhidas para a tomada de dados não correspondem a fisionomias típicas de cerrado pois seu estrato herbáceo tinha sido removido e a área vinha sendo usada como pasto com árvores esparsas. Portanto não havia uma estrato contínuo.

Foi verificada a existência de uma relação do tipo logarítmica entre a quantidade de biomassa lenhosa aérea e o sinal registrado pelo radar. Essa relação é particularmente útil para estimar biomassa em áreas de cerradão, onde o IVDN ou o IVR saturariam. O limite de biomassa que provoca a saturação do sinal na banda L está acima dos valores normalmente encontrados em áreas de cerrado stricto sensu e cerradão. Isso torna as imagens de radar da banda $\mathrm{L}$ úteis para auxiliarem nas estimativas de biomassa vegetal em fisionomias florestais do bioma cerrado. A relação verificada deriva de um baixo número de fisionomias para caracterizar a tendência da curva mais precisamente. Por este motivo se considera apropriado utilizar a curva para estimar intervalos de valores de biomassa vegetal, mas não para valores pontuais. As imagens de radar mostraram ser adequadas para estimar biomassa lenhosa aérea em fisionomias densas de cerrado. Ambos tipos de imagens podem ser complementares na estimativa de biomassa, desde que entendidos os limites de sazonalidade que afetam o bioma cerrado.

A quantificação da biomassa das árvores foi feita utilizando duas equações alométricas desenvolvidas para condições similares às da área de estudo, tendo-se 
obtido resultados similares. No entanto, teriam sido obtidos resultados mais representativos da realidade se o cálculo tivesse sido feito através de diferentes equações, cada uma desenvolvida para a espécie amostrada, ao invés de utilizar as mesmas equações para diferentes espécies. A carência desse tipo de equações levou à utilização de uma única equação para todas as espécies. É difícil de se quantificar o erro em que se incorreu devido a esse procedimento.

Considera-se importante ressaltar que, tanto os valores de retroespalhamento determinados para as áreas amostradas quanto a tendência da curva que descreve a relação entre essa variável e a quantidade de biomassa estão de acordo com trabalhos na mesma linha de pesquisa.

É importante salientar que a validade do presente trabalho não esta comprometida pelo fato de as imagens JERS-1 terem sido adquiridas seis anos antes da realização das medições no campo. Sem dúvida, o tempo transcorrido entre 1995 e 1999/2000 poderia ter trazido mudanças no uso da vegetação e que a amplitude dessas mudanças é muito difícil de se quantificar. Contudo, o estado de conservação desses fragmentos estudados foi considerado muito bom em visita realizada em 1999, por botânicos especializados em cerrado, o que sugere que se houve mudanças no referido período, estas não foram muito significativas. É importante salientar, contudo, que a biomassa vegetal aérea registrada pelos métodos de campo levam em conta a presença de folhas e a assinatura espectral na banda $L$ não pois é devida predominantemente ao sinal decorrente da interação da energia com os galhos e troncos. Assim, esta equação fica parcialmente comprometida em ecossistemas com muitas espécies caducifólias. Apesar de não ter sido possível confirmar a complementaridade dos sistemas ópticos e de microondas na estimativa de biomassa vegetal aérea, sugere-se repetir os testes em fisionomias com estrato herbáceo desenvolvido e não antropisado. 


\section{7 - Considerações finais}

Os dados resultantes do Projeto "The Conservation Feasibility of Cerrado Remnants in São Paulo State" (BITENCOURT et al. 2003), mostram que a maioria dos remanescentes de vegetação do bioma cerrado no estado de São Paulo correspondem às formas densas do bioma. Isto pode ser devido ao fato de o Código Florestal proteger somente as fisionomias florestais, permitindo a alteração das outras. Os resultados do presente trabalho provam que a metodologia aplicada e o sensor utilizado são adequados para a estimativa da quantidade de biomassa vegetal aérea em áreas de cerrado denso e cerradão nas condições predominantes do estado de São Paulo. Por esse motivo é possível aplicar a metodologia proposta para refinar os dados disponíveis de levantamentos de remanescentes florestais.

O sinal registrado pelos sensores remotos inclui uma série de interferências que contaminam a informação dos alvos de interesse localizados na superfície da Terra. Por este motivo não sempre é possível comparar os valores registrados por sensores remotos com as medições feitas no campo de alguma variável biofísica.

$\mathrm{O}$ autor sugere o incentivo do desenvolvimento de trabalhos que busquem definir o limite superior de biomassa que pode ser estimado através das imagens de radar banda L, pois há um grande número de dados conflitantes na literatura. 


\section{8 - Referências Bibliográficas}

ABDALA, G.C.; CALDAS, L.S.; HARIDASAN, M.; EITEN, G. Above and belowground organic matter and root:shoot ratio in a cerrado in Central Brazil. Brazilian Journal of Ecology, v. 2, n. 1, p. 11-23, 1998.

ALVIM, P.; ARAÚJO, W. A. El suelo como factor ecológico em el desarrollo de la vegetación en el centro-oeste del Brasil. Turrialba, v. 2, n. 4, p. 153-160. 1952.

ANTUNES, M. A. H. 6S 4.1.

ARAUJO, L. S.; SANTOS, J. R., FREITAS, C. C.; XAUD, H. A. M. The use of microwave and optical data for estimating aerial biomass of the savannah and forest formations at Roraima State, Brazil. IN: IEEE 1999 IGARSS Proceedings CD-ROM. 1999.

ART, H. W. (ed) Dicionário de ecologia e ciências ambientais. Rio Claro: Ed. UNESP, Melhoramentos. 583p. 2001.

ASNER, G. P. Biophysical and Biochemical Sources of Variability in Canopy Reflectance. Remote Sensing of Environment, v. 64, p. 234-253. 1998.

AUSTIN, J. M.; MACKEY, B. G.; VAN NIEL, K. P. Estimating forest biomass using satellite radar: an exploratory study in a temperate Australian Eucalyptus forest Forest Ecology and Management, n. 6040, p. 1-9. 2002.

BATALHA, M. A.; MANTOVANI, W.; MESQUITA JR, H. N. DE. Vegetation structure in cerrado physiognomies in south-eastern Brazil. Brazilian Journal of Biology, v. 61, n. 3, p. 475-483. 2001

BEGON, M.; HARPER, J.L.; TOWNSEND, C.R. Ecology: individuals, populations and communities. Oxford: Blackwell Scientific Publications. 1986.

BERGEN, M. B.; DOBSON, M. C. Integration of remotely sensed radar imagery in modeling and mapping of forest biomass and net primary production. Biological Modelling, v. 12, p. 257-274. 1999.

BITENCOURT, M. D.; MESQUITA, H. N. DE, KUNTSCHIK, G. Calibrating physiognomies and woody biomass using SAR and optical images, in the cerrado biome of the State of São Paulo, Brazil. Advanced SAR Workshop 2003.

Proceedings. CD ROM. St. Hubert, Quebec, Canadá. 27-27 June 2003.

BITENCOURT PEREIRA, M. D. Correlação de fitomassa foliar de campo cerrado com dados espectrais obtidos pelo sistema MSS/Landsat e por radiometria de campo. 1986. 90 f. Tese (Mestrado em Sensoriamento Remoto) Instituto Nacional de Pesquisas Espaciais. São José dos Campos. 
BOELMAN, N. T.; STIEGLITZ, M. RUETH, H. M.; SOMMERKORN, M.;

GRIFFIN K. L.;'SHAVER, G. R. GAMON, J. A. Response of NDVI, biomass, and ecosystem gas exchange to long-term warming and fertilization in wet sedge tundra. Oecologia, v. 135, p. 414-421. 2003.

BROWN, S.; GILLESPIE, A. J. R.; LUGO, A. E. Biomass estimation methods for tropical forests with applications to forest inventory data. Forest Science, v. 35, n. 4, p. 881-902. 1989.

BURROWS, W. H.; HENRY, B. K.; BACK, P. V.; HOFFMANN, M. B.; TAIT, L. J.; ANDERSON, E. R.; MENKE, N.; DANAHER, T., J.; CARTER, O.; MCKEON, G. M. Growth and carbon stock change in eucalypt woodlands in northeast Australia: ecological and greenhouse sink implications. Global Change Biology, v. 8, n. 8, p. 769. 2002.

CARLSON, T.; RIPLEY, D. A. On the relation between NDVI, fractional vegetation cover and leaf area index. Remote Sensing of Environment, v. 62, p. 241-252. 1997.

CHAVEZ, P. S. Jr. An improved dark-object subtraction technique for atmospheric scattering correction of multispectral data. Remote Sensing of Environment, v. 24, p. 459-479. 1988.

CASTEL,T.; GUERRA, F.; CARAGLIO, Y.; HOULLIER, F. Retrieval biomass of a large Venezuelan pine plantation using JERS-1 SAR data. Analysis of forest structure impact on radar signature. Remote Sensing of Environment, v. 79, p. 30- 41. 2002.

CASTRO, E. A.; KAUFFMAN, J. B. Ecosystem structure in the Brazilian Cerado: a vegetation gradient of aboveground biomass, root biomass and consumption by fire.

Journal of Tropical Ecology, v. 14, p. 263-283. 1998.

CECCATO, P.; GOBRON, N.; FLASSE, S.; PINTY, B.; TARANTOLA, S.

Designing a spectral index to estimate vegetation water content from remote sensing data: Part 1 Theoretical approach. Remote Sensing of Environment, v. 82, p. 188197. 2002.

CIÊNCIA HOJE. A questão ambiental no Brasil (Ed.). v. 22, n. 128, p. 1. 1997.

COLE, M. M. The savannas: biogeography and geobotany. Academic Press Inc. UK. 1986. 438 p.

Cerrado, caatinga and pantanal: the distribution and origim of the savanna vegetation of Brazil. Geographical Journal, v. 126, n. 2, p. 168-179. 1960.

COUTINHO, L. M. O cerrado e a ecologia do fogo. Ciência Hoje, v. 12, n. 68, p. 22-30. 1990. 
COUTINHO, L. M. O conceito de cerrado. Revista Brasileira de Botânica, v. 1, p. 17-23. 1978.

COTTAM, G.; CURTIS, J. T. The use of distance measures in phytosociological sampling. Ecology, v. 37, n. 3, p. 451-460, 1956.

DALLEMAND, J.F.; LICHTENEGGER, J.; RANEY, R.K.; SCHUMANN, R. Principes d'imagerie radar. Rome, FAO/ESA, 1991. (RSC Series 67).

DELITTI, W. B. C.; PAUSAS, J. G.; BURGUER, D. B. Belowground biomass seasonal variation in two Neotropical savannahs (Brazilian Cerrados) with different fire histories. Annals of Forest Science, v. 58, p. 13-721. 2001

DELITTI, W. B. C.; MEGURO, M.; PAUSAS, J. Allometric relations and biomass estimates in cerrado ecosystems. Não publicado. Comunicação pessoal. São Paulo, 2002. 34 p.

DÍAZ-BALTEIRO, L.; ROMERO, C. Carbon captured as a new instrument in Forest management: some implications. Scientia Forestalis, v. 63, p. 103-114. 2003.

DONG, J.; KAUFMANN, R. K.; MYNENI, R. B.; TUCKER,C. J. KAUPPI, P. E.; LISKI, J.; BUERMANN, W.; ALEXEYEV, V.; HUGHES, M. K. Remote sensing estimates of boreal and temperate forest woody biomass: carbon pools, sources, and sinks. Remote Sensing of Environment, v. 84, p. 393-410. 2003

DURIGAN, G. Levantamento Botânico Expedito no Município de Campos Novos Paulista SP. Disponível em: <http://sinbiota.cria.org.br/>. Acesso: 09 de setembro 2000.

DURIGAN, G.; SIQUEIRA, M.F.; FRANCO, G. A. D. C.; BRIDGEWATER, S.; RATTER, J. A. The vegetation of priority areas for cerrado conservation in São Paulo State, Brazil. Edinburgh Journal of Botany, v. 60, n. 2, p. 217-241. 2003.

EITEN, G. The cerrado vegetation of Brazil. The Botanical Review, v. 38, n. 2, p. 201-341. 1972

ELACHI, C. Introduction to the physics and techniques of remote sensing. Pasadena. John Wiley, 1988. 413 p.

FASSNACHT, K. S.; GOWER, S. T.; MACKENZIE, M. D.; NORDHEIM, E. V.; LILLESAND, T. M. Estimating the leaf area index of North Central Winsconsin forests using the Landsat Thematic Mapper. Remote Sensing of Environment, v. 61, p. 229-245. 1997.

FEARNSIDE, P. M. Amazonian deforestation and global warming: carbon stocks in vegetation replacing Brazil's Amazon forest. Forest Ecology and Management, v. 80, p. 21-34. 1996. 
FERREIRA, L.G.; YOSHIOKA, H.; HUETE, A.; SANO, E. E. Seasonal landscape and spectral vegetation index dynamics in the Brazilian Cerrado: An analysis within the Large-Scale Biosphere-Atmosphere Experiment in Amazonnia (LBA). Remote Sensing of Environment. v. 87, p. 534-550. 2003.

FERREIRA, L.G.; YOSHIOKA, H.; HUETE, A.; SANO, E. E. Optical characterization of the Brazilian Savanna physiognomies for improved land cover monitoring of the cerrado biome: preliminary assessments from an airborne campaign over an LBA core site. Journal of Arid Environments. v. 56, p. 425-447. 2004.

FOODY, G. M., CUTLER, M. E.; MCMORROW, J.; PELZ, D.; TANGKI, H.; BOYD, D. S.; DOUGLAS, I. Mapping the biomass of Bornean tropical rain forest from remotely sensed data. Global Ecology \& Biogeography. v. 10, p. 379-387, 2001.

FOODY, G. M.; GREEN, R. M.; LUCAS, R. M.; CURRAN, P. J.; HONZAK, M.; DO AMARAL, I. Observations on the relationship between SIR-C radar backscatter and the biomass of regenerating tropical forests. International Journal of Remote Sensing, v. 18, n. 3, p. 687-694. 1997.

FOODY, G.M.; PALUBINSKAS, G.; LUCAS, R.M.; CURRAN, P.J.; HONZAK, M. Identifying terrestrial carbon sinks: classification of successional stages in regenerating tropical forest from Landsat TM data. Remote Sensing of Environment, v. 55, p. 205-216, 1996.

FOODY, G. M.; BOYD, D. S.; CUTLER, M. E. J. Predictive relations of tropical forest biomass from Landsat TM data and their transferability between regions. Remote Sensing of Environment, v. 85, p. 463-474, 2003.

FORMAGGIO, A. R.; EPIPHANIO, J. C. N.; VALERIANO, M. M.; OLIVEIRA, J. B. Comportamento espectral $(450-2450 \mathrm{~nm})$ de 14 classes de solos tropicais brasileiros. Revista Brasileira de Ciência do Solo, v. 20, p. 467 - 474, 1996.

FURLEY, P. A. The nature and diversity of neotropical savanna vegetation with particular reference to the Brazilian cerrados. Global Ecology \& Biogeography, v. 8, n. 3-4, p. 223-241. 1999

FURLEY, P. The influence of slope on the nature and distribution of soils and plant communities in the central Brazilian cerrado. IN: Advances in hillslope processes, Vol. 1. Anderson, M. G.; Brooks, M. (ed). John Wiley \& Sons. 1996.

FURLEY, P. A.; RATTER, J. A. Soil resources and plant communities of the Central Brazilian Cerrado and their development. Journal of Biogeography, v.1, n. 15, p. 97-108, 1998.

GALVÃO, L. S.; VITORELLO, I.; ALMEIDA FILHO, R. Effects of Band Positioning and Bandwidth on NDVI Measurements of Tropical Savannas. Remote Sensing of Environment, v. 67, p. 181-193, 1999. 
GALVÃO, L. S.; VITORELLO, I.; PIZARRO, M. A. An adequate band positioning to enhance NDVI contrast among green vegetation, senescent biomass and tropical soils. International Journal of Remote Sensing, v. 21, n. 9, p. 1953-1960. 2000.

GILABERT, M. A.;GONZÁLEZ-PIQUERAS, J.; GARCÍA-HARO, F.;MELIÁ, J. A generalized soil-adjusted vegetation index. Remote Sensing of Environment, v. 82, p. 303-310. 2002.

GITELSON, A. A.; KAUFMAN, Y. J.; STARK, R.; RUNQUIST, D. Novel algorithms for remote estimation of vegetation fraction. Remote Sensing of Environment, v. 80, p. 76- 87. 2002.

GOODLAND, R.; POLLARD, R. The Brazilian cerrado vegetation: a fertility gradient. Journal of Ecology, v. 61, p. 219-224, 1973.

GOWER, S. T.; KUCHARIK, C. J.; NORMAN, J. M. Direct and indirect estimation of leaf area index, fapar, and net primary production of terrestrial ecosystems.

Remote Sensing of Environment, v. 70, p. 29-51, 1999.

GUPTA, R. K.; PRASAD, T. SD. Relationship between LAI and NDVI for IRSS LISS and Landsat TM bands. Advances in Space Research, v. 26, n. 7, p. 10471050. 2000.

HARRELL, P. A.; BORGEAU-CHAVEZ, L. L.; KASISCHKE, E. S.; FRENCH, N. H. F.; CHRISTENSEN Jr., N. H. L. Sensitivity of ERS-1 and JERS-1 radar data to biomass and stand structure in Alaskan boreal forest. Remote Sensing of Environment, v. 54, p. 247-260. 1995.

HASHIM, M.; HAZLI, W.; KADIR, W.; YOONG, L. K. Global rain forest mapping activities in Malaysia: radar remote sensing for forest survey and biomass indicators. JERS-1 Science Program '99 PI reports. Global forest monitoring and SAR interferometry. Earth Observation Research Center, National Space Development Agency of Japan. 1999.

HOLBEN, B.N.; TUCKER, C.J. Spectral assessment of soybean leaf area and leaf biomass. Photogrammetric Engineering and Remote Sensing, v. 46, n. 5, p. 651656,1980 .

HOUGHTON J. T; DING, Y; GRIGGS, D. J.; NOGUER, M; VAN DER LINDEN, P. J.; DAI, X; MASKELL, K; JOHNSON, C. A (ed) IPCC Summary for Policy Makers. In Climate Change 2001: The Scientific Basis. Contribution of Working Group I to the Third Assessment Report of the Intergovernmental Panel on Climate Change, Cambridge University Press, Cambridge, United Kingdom and New York, NY, EUA. 2001.

HU, B.; LUCHT, W.; STRAHLER, A. H.; SCHAAF, C. B.; SMITH, M. Surface Albedos and Angle-Corrected NDVI from AVHRR Observations of South America. Remote Sensing of Environment, v. 71, p. 119-132. 2000. 
HUETE, A. R. A soil-adjusted vegetation index (SAVI). Remote Sensing of Environment, v. 25, p. 295-309. 1988.

HUETE, A.; LIU, H. Q.; BATCHILY, K.; VAN LEEUWEN, W. A comparison of vegetation indices over a global set of TM images for EOS-MODIS. Remote Sensing of Environment, v. 59, p. 440-451. 1997.

HUETE, A.; LIU, H. Q.; VAN LEEUWEN, J. D. The use of vegetation indices in forested regions: issues of linearity and saturation. IEE Transactions on Geosciences and remote sensing IN: Proceedings_of IGARSS '97 - International Geosciences and Remote Sensing Seminar 4:1966-1968. Noordwijk, The Netherlands: ESA Publications. 1997.

\section{HUETE, A.; JUSTICE, C.; VAN LEEUWEN, J. D. MODIS Vegetation Index} (Mod 13), EOS MODIS Algorithm Theoretical Basis Document Version 3. NASA Goddard Space Flight Center, Greenbelt, Maryland 20771, 1999

HUETE, A.; DIDAN , K.; MIURA , T.; RODRIGUEZ, E. P.; GAO , X.; FERREIRA, L. G. Overview of the radiometric and biophysical performance of the MODIS vegetation indices. Remote Sensing of Environment, v. 83, p.195-213. 2002.

HYYPPA, J.; HYYPPA, H.; INKINEN, M.; ENGDAHL, M.; LINKO, S.; ZHU, Y. Accuracy comparison of various remote sensing data sources in the retrieval of forest stand attributes. Forest Ecology and Management, v. 128, p.109-120, 2000.

IMHOFF, M. L. Radar backscatter and biomass saturation: ramifications for global biomass inventory. IEEE Transactions on Geoscience and Remote Sensing, v. 23, n. 2, p. 511-518. 1995.

IBGE - INSTITUTO BRASILEIRO DE GEOGRAFIA E ESTATÍSTICA Atlas do Brasil (escala 1:1 000.000), Mapa da Vegetação do Brasil. Rio de Janeiro: Instituto Brasileiro de Geografia e Estatística, 1992.

IBGE - INSTITUTO BRASILEIRO DE GEOGRAFIA E ESTATÍSTICA. Carta do Brasil (escala 1:50.000), Campos Novos Paulista, Folha SF-22-Z-A-V-2. Instituto Brasileiro de Geografia e Estatística, Rio de Janeiro. 1975.

JACKSON, R. D.; HUETE, A. R. Interpreting vegetation indices. Preventive Veterinary Medicine, v. 11, p. 185-200. 1991.

JANSSENS,I. A.; FREIBAUER, A.; CIAIS, P.; SMITH, P, NABUURS, G. J.; FOLBERTH, G.; SCHLAMDINGER, B.; HUTJES, R. W. A.; CEULEMANS, R.; SCHLUZE, E. D.; VALENTINI, R. Europe's Terrestrial Biosphere Absorbs 7 to $12 \%$ of European Anthropogenic $\mathrm{CO}_{2}$ Emissions. Science, v. 300, p. 1538-1542. 2003.

JENSEN, J. R. Remote sensing of the environment. An Earth resource perspective. Prentice Hall series in Geographic Information Systems. UK. 
JOHNSON, C. M.; VIEIRA, I. C. G.; ZARIN, D. J.; FRIZANO, J.; JOHNSON, A. H. Carbon and nutrient storage in primary and secondary forests in eastern Amazônia. Forest Ecology and Management, v. 147, p. 245-252. 2001.

JORDAN, C. F. Derivation of leaf-area index from quality of light on the Forest floor. Ecology, v. 40, n. 4, p. 663-666. 1969.

JUSTICE, C.O.. Monitoring the grasslands of semi-arid Africa using NOAA-AVHRR data. International Journal of Remote Sensing, v.7, p. 1383-1622. 1986.

KAMPEL, S. A.; SHIMABUKURO, Y. E.; VALERIANO, D. M.; KUNTSCHIK, G.; PEREIRA, J. L. G.; AHERN, F. J. Correlation between forest and optical and microwave remote sensing parameters at Tapajós National Forest, Brazilian Amazon, In: VIII Simpósio Latinoamericano de Percepción Remota, Mérida, Venezuela. ANAIS CD ROM. 1997

KASISCHKE, E. S.; MELACK, J. M.; DOBSON, M. C. The use of imaging radars for ecological applications - a review. Remote Sensing of Environment, v. 59, p. 141-156. 1997.

KAUFFMAN, J. B.; CUMMINGS D. L.; WARD, D. E. Relationships of fire, biomass and nutrient dynamics along a vegetation gradient in the Brazilian Cerrado.

Journal of Ecology, v. 82, n. 3, p. 519-531, 1994.

KAUFMAN, Y.J. TANRÉ, D. Atmospherically resistant vegetation index (ARVI) for EOS-MODIS. IEEE Transactions on Geoscience and Remote Sensing, v. 30, p. 261-270, 1992.

KING, D.A. Allometry of saplings and understorey trees of a Panamanian forest. Functional ecology, n. 4, p.27-32, 1990.

KING, D. Allometry and life history of tropical trees. Journal of Tropical Ecology, n. 12 , p. $25-44,1996$

KÖPPEN, W. Climatologia con un estúdio de los climas de la tierra. Fondo de Cultura Econômica. México. 478p. 1948

DE KONING, F.; OLSCHEWSKI,R.; VELDKAMP, E.; BENÍTEZ, P.; LACLAU, P.; LÓPEZ,M.; URQUIZA, M.; SCHLICHTER, T. Tropical Forest Research: Evaluation of the $\mathrm{CO}_{2}$ sequestration potential of afforestation projects and secondary forests in two different climate zones of South America. Deutsche Gesellschaft für Technische Zusammenarbeit (GTZ) GmbH, Eschborn, Alemanha, 2002.

KRONKA, F.; MATSUKUMA, C. K.; NALON, M. A.; DEL CALI, I. H.; ROSSI, M.; MATTOS, I. F. A.; SHIN-IKE-YWANE, M. S.; PONTINHAS, A. A. S.

Inventario florestal do Estado de São Paulo. Instituto Florestal do Estado de São Paulo/ SEMA. 1993. 
KYOTO PROTOCOL TO THE UNITED NATIONS FRAMEWORK

CONVENTION ON CLIMATE CHANGE. English Conference of the Parties. Third session Kyoto, 1-10. Dezembro 1997.

LAMBIN, E. F. Monitoring forest degradation in tropical regions by remote sensing: some methodological issues. Global Ecology \& Biogeography, v. 8, n. 3-4, p. 191198, 1999.

LARK, R. M.; WHEELER, H. C. Understanding and using yield maps - an analytical tool for their interpretation. Outlook on Agriculture, v. 29, n.1, p. 39-45. 2000.

LICOR. LAI-2000 Plant canopy analyzer: Instruction manual. Lincoln, Nebraska, USA. 1992. 182p.

LILLESAND, T. M.; KIEFER, R. W. Remote sensing and image interpretation. 3 ed. John Wiley \& Sons Inc. 1994. 750 p.

LIU, W. K.; KOGAN, F. Monitoring Brazilian soybean production using NOAA/AVHRR based vegetation condition indices. International Journal of Remote Sensing, v. 23, n. 6, p. 1161-1179. 2002.

LUCKMAN, A., BAKER, J.; HONZÁK, M.; KUPLICH, T. M; YANASSE, C. C. F.; FRERY, A. A study of the relationship between radar backscatter and regenerating tropical Forest biomass for spaceborne SAR instruments. Remote sensing of Environment, v. 60, p. 1-13. 1997.

LUCKMAN, A.; BAKER, J.; HONZÁK, M.; LUCAS, R. Tropical Forest Biomass Density Estimation Using JERS-1 SAR: Seasonal Variation, Confidence Limits, and Aplication to Image Mosaics. Remote Sensing of Environment, v. 63, p. 126-139. 1998.

MANTOVANI, W. Estrutura e dinâmica da Floresta Atlântica na Jureia, Iguape - SP. 1993. 126 f. Tese (Livre Docente) - Instituto de Biociências, Universidade de São Paulo. São Paulo.

MANTOVANI, W. Comunicação pessoal, 2001.

MARMORI, M. O fogo na justa medida. Ciência Hoje, v. 12, n. 68, p. 68. 1990.

MARTINS, F. R. Estrutura de uma floresta mesófila. Editora da UNICAMP. Campinas, 1993. 246 p.

MATTEUCCI, S.D.; COLMA, A. Metodología para el estudio de la vegetación. Secretaría Geral da Organização dos Estados Americanos, Wasington. 163p. 1982.

MAYAUX, P.; ACHARD, F.; MALINGREAU, J. P. Global tropical forest area measurements derived from coarse resolution satellite imagery: a comparison with other approaches. Environmental Conservation, 25 (1):37-52, 1998. 
MAYAUX, P.; DE GRANDI,G.; MALINGREAU, J. P. Central African Forest Cover Revisited: A Multisatellite Analysis. Remote Sensing of Environment, 71:183-196. 2000.

MENIZER, F. C.; GOLDSTEIN, G.; FRANCO, A. C.; BUSTAMANTE, M.; IGLER, E.; JACKSSON, P.; CALDAS, L.; RUNDELL, P. W. Atmospheric and hidraulic limitations on transpiration in Brazilian Cerrado woody species. Functional Ecology, 13(2):273-282, 1999.

MESQUITA JR, H. N. Análise temporal com sensor orbital de unidades fisionômicas de cerrado na Gleba Pé-de-Gigante (Parque Estadual de Vassununga- SP). 1998. 127 f. Tese (Mestrado em Ecologia) - Instituto de Biociências, Universidade de São Paulo. São Paulo.

MESQUITA JR, H. N. Modelagem da resposta espectral das fisionomias de Cerrado em relação às variações climáticas sazonais. 2003. $244 \mathrm{f}$. Tese (Doutorado em Ecologia) do Instituto de Biociências. São Paulo: Universidade de São Paulo.

MIURA, T.; HUETE, A. R.; YASHIOKA, H.; NOLBEN, B. N. An error and sensitivity analysis of atmospheric resistant vegetation indices derived from dark target-based atmospheric correction. Remote Sensing of Environment, 78:284298. 2001.

MODIS Profundidade óptica da atmosfera em 5 de junho de 2002. Consulta ao banco de dados. Disponível em: http://modis-

atmos.gsfc.nasa.gov/IMAGES/index_mod08d3h.html. acesso em 03 de novembro 2003.

MOREAU, S.; LE TOAN, T. Biomass quantification of Andean wetland forages using ERS satellite SAR data for optimizing livestock management. Remote Sensing of Environment, 84:477-492. 2003.

MOURA, M. L. DE; GALVÃO, L. S. Smoke effects on NDVI determination of savannah vegetation types. International Journal of Remote Sensing, 24(21):42254231. 2003.

MUELLER-DOMBOIS, D, ELLENBERG, H. Aims and Methods of Vegetation Ecology. New York: Wiley, 547p. 1974.

MYERS, N.; MITTERMEIER, R. A.; MITTERMEIER, C. G.; da FONSECA, G. A. B.; KENT, J. Biodiversity hotspots for conservation priorities. Nature, 403: 853858. 2000.

MYNENI, R. B.; DONG, R.B.; TUCKER, J.; KAUFMANN, C.J.; KAUPPI, R.E.K.; LISKI, P.E.J.; ZHOU, L.; ALEXEYEV, V.; HUGHES, M. K. A large carbon sink in the woody biomass of Northern forests. Proceedings of the National Academy of Sciences of the United States of America, 98(26):14784-14789. December 18, 2001. 
NACKAERTS, K.; COPPIN, P.; MUYS, B.; HERMY, M. Sampling methodology for LAI measurements with LAI-2000 in small forest stands. Agricultural and Forest Meteorology, 101:247-250. 2000.

NELSON, R. F.; KIMES, D. S.; SALAS, W. A.; ROUTHIER, M. Secondary forest age and tropical forest biomass estimation using Thematic Mapper imagery.

BioScience, v. 50, n. 5, p. 419-431, 2000.

OHSUMI, T. Ocean storage, including costs and risks. IN: Intergovernmental Panel on Climate Change, Working Group III: Mitigation of Climate Change. IPCC workshop on carbon dioxide capture and storage. Proceedings. Regina, Canada, 1821 November 2002. 69-78

OLIVEIRA, J. B.; CAMARGO, M. N.; ROSSI, M.; CALDERANO FILHO, B. Mapa pedológico do Estado de São Paulo. Legenda expandida. Campinas, Instituto Agronômico de Campinas. Rio de Janeiro, RJ. Embrapa. 1999. 64 p.

OLIVEIRA FILHO, A. T.; SHEPHERD, G. J.; MARTINS, F. R.; STUBBLEBINE, W. H. Environmental factors affecting physiognomic and floristic variation in an area of cerrado in Central Brazil. Journal of Tropical Ecology, 5(4):413-431, 1989.

OTTMAR, R. D.; VIHNANEK, R. E.; MIRANDA, H.; SATO, M.; ANDRADE, S. M. A. Stereo photo series for quantifying Cerrado fuels in central Brazil-Volume I. Gen. Tech. Rep. PNW-GTR-519. Portland, OR: US Department of Agriculture, ForestService, Pacific Northwest Research Station. 87p. 2001.

PIVELLO, V. R.; COUTINHO, L. M. A qualitative successional model to assist in the management of Brazilian Cerrados. Forest Ecology and Management, n. 87, p.127-138. 1996.

QUEGAN, S.; LE TOAN, T.; YU, J. J.; RIBBES, F.; FLOURY, N. Multitemporal ERS SAR analysis applied to forest mapping. IEEE Transactions on Geoscience and Remote Sensing, n. 38, p. 741-753. 2000.

RANSON, K. J.; SUN, G.; WEISHAMPEL, J. S.; KNOX, R. G. Forests biomass from combined ecosystem and radar backscatter modeling. Remote sensing of the Environment, n. 50, p.118-133. 1997.

RATTER, J. A.; BRIDGEWATER, S.; RIBEIRO, J.F.; DIAS, T.A B.; SILVA, M.R. Distribuição das espécies lenhosas da fitofisionomia Cerrado sentido restrito nos estados compreendidos pelo bioma Cerrado. Boletim do Herbário Ezechias Paulo Heringer, n.5, p. 5-43. 2000a.

RATTER, J.A.; BRIDGEWATER, S.; RIBEIRO, J.F. Analysis of the floristic composition of the Brazilian cerrado vegetation III: Comparison of woody vegetation of 380 areas. Edinburgh Journal of Botany, n. 60, p. 59-109. 2003. 
RATTER, J.A.; RIBEIRO, J.F.; BRIDGEWATER, S. The Brazilian cerrado vegetation and threats to its biodiversity. Annals of Botany, n. 80, p. 223-230. 1997.

RATTER, J.A.; RIBEIRO, J.F.; BRIDGEWATER, S. Woody flora distribution of the Cerrado Biome: phytogeography and conservation priorities. In: Cavalcanti, T.B. et al. (eds.). Tópicos Atuais em Botânica (Palestras convidadas do 51o Congresso Nacional de Botânica), pp. 340-342. Brasília: EMBRAPA Recursos Genéticos e Biotecnologia/Sociedade Botânica do Brasil. $2000 \mathrm{~b}$.

RIZZINI, C. T. Tratado de fitogeografia do Brasil: aspectos sociológicos e florísticos. 2 vol. Hucitec, Ed. da Universidade de São Paulo. 1979. São Paulo. 374 p. 1979.

ROSENQVIST, A. Evaluation of JERS-1, ERS-1 and ALMAZ SAR backscatter for rubber and oil palm stands in West Malaysia. International Journal of Remote Sensing, n. 21, v. 17, p. 3219-3231, 1996.

SANCHEZ-AZOFEIFA, G. A.; CASTRO, K. L.; RIVARD, B.; KALASCKA, M. R. Remote Sensing Research Priorities in Tropical Dry Forest Environments.

Biotropica, n. 35, v. 2, p.134-142, 2003

SANO, E.E.; PINHEIRO, G.G.C.; MENESES, P.R. Assessing JERS-1 synthetic aperture radar data for vegetation mapping in the Brazilian savanna. Journal of the Remote Sensing Society of Japan, n. 21, v. 2, p. 158-167. 2001.

SANTOS, J. R. Biomassa aérea da vegetação de cerrado: estimativa e correlação com dados do sensor Thematic Mapper do satélite Landsat. 1988. Tese (Doutorado em Engenharia Florestal) - Universidade Federal do Paraná, Curitiba.

SANTOS, J. R.; KEIL, M.; ARAÚJO, L. S.; PARDI LACRUZ, M. S.; KRÄMER, J.C. M.; KANDLER. Biomass estimation of forest and savanna transition vegetation zone by JERS-1 and SIR-C backscatter data. International Archives of

Photogrammetry and Remote Sensing. Amsterdam. v. 33, n. 7, p. 377-381. 2000.

SANTOS, J. R.; PARDI LACRUZ, M. S.; ARAÚJO, L. S.; KEIL, M. Savanna and tropical rainforest biomass estimation and spatialization using JERS-1 data.

International Journal of Remote Sensing. v. 7, n. 23, p. 1217-1229. 2002.

SÃO PAULO. Sistema Integrado de Gerenciamento de Recursos Hídricos -

SIGRH. Consulta ao banco de dados. Disponível em:

$<$ http://www.sigrh.sp.gov.br/sigrh/basecon/bancodedados/plu/plu.htm>. Acesso: 1 de julho 2003.

SCHROEDER, P. E.; WINJUM, J. K. Assessing Brazil's carbon budget: II Biotic fluxes and net carbon balance. Forest Ecology and Management, v. 75, p. 87-99. 1995.

SCHULZE, E. D; WIRTH, C.; HEINMANN, M. Climate Change: Managing Forests After Kyoto. Science, v. 289, p. 2058-2059. 2000. 
SCOLFORO, J. R.; MELLO, J. M. Inventario florestal. Universidade Federal de Lavras, Lavras, MG. 1997. 334p.

SHIMADA, M. User's guide to NASDA's SAR products. Ver. 2. NDX-000291. Tokyo Japan: NASDA. 27 p. 2002.

SMOLANDER, H.; STENBERG, P. Response of LAI-2000 estimates to changes in plant surface area index in a Scots pine stand. Tree Physiology, v. 16, p. 345-349. 1996.

SOKAL, R. R.; ROLF, F. J. Introduction to biostatistics. W. H. Freeman and Co., New York. 1987. 363p.

SPECHT, A.; WEST, P. W. Estimation of biomass and sequestered carbon on farm forest plantations in northern New South Wales, Australia. Biomass and Bioenergy, v. 25 , p. $363-379.2003$.

STATSOFT, INC. Statistica for Windows 5.1. Tulsa, EUA. StatSoft Inc., 1996.

STEVEN, M. D. The sensitivity of the OSAVI Vegetation Index to observational parameters. Remote Sensing of Environment, v. 63. p. 49-60. 1998.

SUN, G.; RANSON, K. J.; KHARUK, V. I. Radiometric slope correction for forest biomass estimation from SAR data estimation from Western Sayani Mountains, Siberia. Remote sensing of the Environment, n. 79, v. 2-3, p. 279-287. 2002.

TANRÉ, D.; DEROO, C.; DUHAUT, P.; HERMAN, M.; MORCRETTE, J. J.; PERBOS, J.; DESCHAMPS, P. Y. Description of a computer code to simulate the satellite signal in the solar spectrum: the $5 \mathrm{~S}$ code. International Journal of Remote Sensing, v. 11, n. 4, p. 659-668. 1990.

THENKABAIL, P. S.; SMITH, R. B.; DE PAUW, E. Hyperspectral Vegetation Indices and Their Relationships with Agricultural Crop Characteristics. Remote Sensing of Environment, v. 71, p. 158-182. 2000.

THE ROYAL SOCIETY. The role of land carbon sinks in mitigating global climate change. Policy document 10/01, Londres, 2001. 35p

TIAN, H.; MELILLO, J. M.; KICKLIGHTER, D. W.; MCGUIRE, A. D.; HELFRICH J.; MOORE, B.; VÖRÖSMARTY, C.J. Climatic and biotic controls on annual carbon storage in Amazonian ecosystems. Global Ecology and Biogeography, v. 9, n. 4, p. 315-335, 2000.

TUCKER C, J. Red and photographic infrared linear combinations for monitoring vegetation. Remote Sensing of Environment, v. 8, p.127-150, 1979.

TUCKER, C. J.; SELLERS, P. J. Satellite remote sensing of primary productivity. International Journal of Remote Sensing, v. 7, p.1395-1416, 1986. 
TUCKER, C. J.; VANPRAET, C. L.; SHARMAN, J.; VAN ITTERSUM, G.. Satellite remote sensing of total herbaceous biomass production in the Senegalese Sahel:

1980-1984. Remote Sensing of Environment, v. 17, p. 233-249, 1985.

TURNER,D. P.; COHEN,W. B.; KENNEDY, R. E.; FASSNACHT, K. S.; BRIGGS, J. M. Relationships between Leaf Area Index and Landsat TM Spectral Vegetation Indices across Three Temperate Zone Sites. Remote Sensing of Environment, v.70, p. 52-68. 1999.

ULABY, F.T.; MOORE, R.K.; FUNG. A.K. Microwave remote sensing: active and passive: Microwave remote sensing fundamentals and radiometry. $\mathrm{v} .1$. Norwood, Artech House, 1981.

VALERIANO, D. M.; BITENCOURT PEREIRA, M. D. Relações entre a biomassa aérea do estrato rasteiro do cerrado e sua reflectância espectral. Instituto Nacional de Pesquisas Espaciais. São José dos Campos, SP. 1989. INPE-4048$\mathrm{PRE} / 1477$

VARGAS, L. A.; ANDERSEN, M.N.; JENSEN, C.R.; JØRGENSEN, U. Estimation of leaf area index, light interception and biomass accumulation of Miscanthus sinensis 'Goliath' from radiation measurements. Biomass and Bioenergy, n. 22, p. $1-14.2002$

VERMOTE, E.F.; TANRE, D.; DEUZE, J.L.; HERMAN, M.; MORCRETTE, J.J. Second simulation of the satellite signal in the solar spectrum, 6S: An overview., IEEE Transactions on Geosciences and Remote Sensing, n. 35 v. 3, p. 675-686. 1997.

WAGNER, W.; LUCKMAN, A.; VIETMEIER, J.; TANSEY, K.; BALZTER, H.; SCHMULLIUS, C.; DAVIDSON, M.; GAVEAU, D.; GLUCK, M.; LE TOAN, T.; QUEGAN, S.; SHVIDENKO, A.; WIESMANN, A.; YU, J. J. Large-scale mapping of boreal forest in SIBERIA using ERS tandem coherence and JERS backscatter data. Remote Sensing of Environment, v. 85, p. 125-144, 2003.

WARING, R. H.; WAY, J. B.; HUNT JR, E. R.; MORRISSEY, L.; RANSON, K. J.; WEISHAMPEL, J. F.; OREN, R.; FRANKLIN, S. E. Imaging radar for ecosystem studies. BioScience, v. 45, n. 10, p. 715-723. 1995.

XAUD, M. R. Avaliação de dados TM/Landsat e SAR/JERS na caracterização da cobertura vegetal e distribuição de fitomassa em áreas de contato floresta/savana no Estado de Roraima-Brasil. 1998. Tese (Mestrado em Sensoriamento Remoto) - Instituto Nacional de Pesquisas Espaciais. São José dos Campos.

XIAO, X.; BRASWELL, B.; ZHANG, Q.; BOLES, S.; FROLKING, S.; MOORE III, B. Sensitivity of vegetation indices to atmospheric aerosols: continental-scale observations in Northern Asia. Remote Sensing of Environment, v. 84, p. 385392, 2003. 
ZAK, M.; CABIDO, M. Land-cover types in central Argentina based on Landsat TM and phytosociological data. Applied Vegetation Science, v. 5, n. 2, p. 213-226, 2002.

ZULLO Jr., J. Correção Atmosférica de Imagens de Satélite e Aplicações. 1994. 190 f. Tese (Doutorado em Engenharia Elétrica) - Faculdade de Engenharia Elétrica. Universidade de Campinas, Campinas.

ZULLO Jr., J.; GUYOT, G.; GU, X. F.; BEZERRA, P. C. 1994. Importância da correção atmosférica no cálculo do índice de vegetação a partir de imagens de satélite. IN: Congresso Brasileiro de Engenharia Agrícola, 23., Campinas, jul. 1994. Anais. Campinas: UNICAMP, 1994. p. 1-12. 


\section{Anexo 1}

Valores das variáveis biofísicas levantadas para as 800 árvores amostradas nas áreas 1B a 10B (Quadr.: quadrante; Dist: distância em metros; Alt.: altura em metros; AB: área basal em centímetros quadrados).

\section{Área 1B}

Biomassa: 1,7 T/ha.

Área basal média: $0,55 \mathrm{~m}^{2} / \mathrm{ha}$.

6,8 árvores/ha.

\begin{tabular}{|c|c|c|c|c|c|}
\hline Quadr. & Indivíduo & Dist. (m) & Alt. $(\mathrm{m})$ & $\mathrm{AB}\left(\mathrm{cm}^{2}\right)$ & Biomassa(Kg \\
\hline \multirow{4}{*}{1} & 1 & 67,0 & 10 & 1986,6 & 748,5 \\
\hline & 2 & 28,7 & 8 & 368,0 & 111,6 \\
\hline & 3 & 1 & 5 & 378,9 & 71,9 \\
\hline & 4 & 40,7 & 4,5 & 588,6 & 100,5 \\
\hline \multirow{4}{*}{2} & 1 & 49,7 & 8 & 795,8 & 240,8 \\
\hline & 2 & 28 & 3 & 71,6 & 8,2 \\
\hline & 3 & 54,5 & 4 & 1011,2 & 153,2 \\
\hline & 4 & 32 & 10 & 2958,2 & 1113,2 \\
\hline \multirow{4}{*}{3} & 1 & 7,6 & 7 & 1609,7 & 425,4 \\
\hline & 2 & 35,9 & 6,5 & 1363,7 & 334,9 \\
\hline & 3 & 87 & 9 & 3296,8 & 1116,6 \\
\hline & 4 & 60 & 10 & 1559,7 & 588,2 \\
\hline \multirow{4}{*}{4} & 1 & 16 & 7 & 223,5 & 59,5 \\
\hline & 2 & 53,6 & 3,5 & 92,0 & 12,3 \\
\hline & 3 & 14,8 & 8 & 1559,7 & 470,9 \\
\hline & 4 & 39,4 & 4 & 1493,6 & 226,0 \\
\hline \multirow{4}{*}{5} & 1 & 4 & 7 & 325,9 & 86,6 \\
\hline & 2 & 77,5 & 4 & 223,5 & 34,0 \\
\hline & 3 & 25 & 4 & 189,5 & 28,9 \\
\hline & 4 & 24,2 & 4 & 331,1 & 50,4 \\
\hline \multirow{4}{*}{6} & 1 & 52,7 & 6 & 962,9 & 218,6 \\
\hline & 2 & 15,4 & 5 & 564,2 & 107,0 \\
\hline & 3 & 22,2 & 8 & 496,6 & 150,5 \\
\hline & 4 & 47,1 & 3,5 & 255,3 & 34,0 \\
\hline \multirow{4}{*}{7} & 1 & 36 & 10 & 1656,5 & 624,5 \\
\hline & 2 & 18,3 & 8 & 574,9 & 174,2 \\
\hline & 3 & 17,3 & 3 & 249,3 & 28,5 \\
\hline & 4 & 40 & 5 & 175,8 & 33,5 \\
\hline \multirow{4}{*}{8} & 1 & 35 & 14 & 2872,7 & 1511,9 \\
\hline & 2 & 12 & 5 & 207,0 & 39,4 \\
\hline & 3 & 38 & 8 & 844,2 & 255,4 \\
\hline & 4 & 109,5 & 8 & 616,2 & 186,6 \\
\hline \multirow[t]{2}{*}{9} & 1 & 18,6 & 5 & 315,8 & 60,0 \\
\hline & 2 & 13,3 & 3,5 & 108,9 & 14,6 \\
\hline
\end{tabular}




\begin{tabular}{|c|c|c|c|c|c|}
\hline Quadr. & Indivíduo & Dist. (m) & Alt. (m) & $\mathrm{AB}\left(\mathrm{cm}^{2}\right)$ & Biomassa(Kg \\
\hline & 3 & 45 & 7 & 481,7 & 127,8 \\
\hline & 4 & 44,5 & 8 & 684,2 & 207,1 \\
\hline \multirow{4}{*}{10} & 1 & 57,5 & 5 & 229,6 & 43,7 \\
\hline & 2 & 47,4 & 4,5 & 147,1 & 25,2 \\
\hline & 3 & 48,3 & 3,5 & 198,9 & 26,5 \\
\hline & 4 & 67 & 7 & 658,3 & 174,5 \\
\hline \multirow{4}{*}{11} & 1 & 76 & 4,5 & 147,1 & 25,2 \\
\hline & 2 & 33,5 & 7 & 1609,7 & 425,4 \\
\hline & 3 & 84 & 4 & 331,1 & 50,4 \\
\hline & 4 & 7,4 & 3 & 249,3 & 28,5 \\
\hline \multirow{4}{*}{12} & 1 & 18,2 & 14 & 2872,7 & 1511,9 \\
\hline & 2 & 67,2 & 5 & 207,0 & 39,4 \\
\hline & 3 & 33 & 5 & 315,8 & 60,0 \\
\hline & 4 & 52 & 10 & 1986,6 & 748,5 \\
\hline \multirow{4}{*}{13} & 1 & 28,7 & 8 & 574,9 & 174,2 \\
\hline & 2 & 3,9 & 9 & 3296,8 & 1116,6 \\
\hline & 3 & 40,7 & 5 & 175,8 & 33,5 \\
\hline & 4 & 79,7 & 3 & 108,9 & 12,5 \\
\hline \multirow{4}{*}{14} & 1 & 22,1 & 7 & 223,5 & 59,5 \\
\hline & 2 & 9,7 & 4 & 92,0 & 14,0 \\
\hline & 3 & 39,4 & 7 & 481,7 & 127,8 \\
\hline & 4 & 61,6 & 8 & 616,2 & 186,6 \\
\hline \multirow{4}{*}{15} & 1 & 28 & 7 & 325,9 & 86,6 \\
\hline & 2 & 55 & 5 & 229,6 & 43,7 \\
\hline & 3 & 17,3 & 4 & 1493,6 & 226,0 \\
\hline & 4 & 18,3 & 10 & 1656,5 & 624,5 \\
\hline \multirow{4}{*}{16} & 1 & 35,5 & 3 & 255,3 & 29,2 \\
\hline & 2 & 38 & 5 & 223,5 & 42,5 \\
\hline & 3 & 90,9 & 5 & 564,2 & 107,0 \\
\hline & 4 & 30,6 & 5 & 378,9 & 71,9 \\
\hline \multirow{4}{*}{17} & 1 & 45 & 8 & 1559,7 & 470,9 \\
\hline & 2 & 25 & 8 & 496,6 & 150,5 \\
\hline & 3 & 35 & 3,5 & 198,9 & 26,5 \\
\hline & 4 & 24,2 & 8 & 368,0 & 111,6 \\
\hline \multirow{4}{*}{18} & 1 & 48 & 6,5 & 1363,7 & 334,9 \\
\hline & 2 & 13,3 & 8 & 844,2 & 255,4 \\
\hline & 3 & 8 & 4 & 1011,2 & 153,2 \\
\hline & 4 & 20,3 & 8 & 795,8 & 240,8 \\
\hline \multirow{4}{*}{19} & 1 & 53,5 & 4,5 & 588,6 & 100,5 \\
\hline & 2 & 47,4 & 6 & 962,9 & 218,6 \\
\hline & 3 & 15,4 & 4 & 189,5 & 28,9 \\
\hline & 4 & 52,7 & 3 & 71,6 & 8,2 \\
\hline \multirow{4}{*}{20} & 1 & 46,7 & 7 & 658,3 & 174,5 \\
\hline & 2 & 18,6 & 10 & 2958,2 & 1113,2 \\
\hline & 3 & 45 & 10 & 1559,7 & 588,2 \\
\hline & 4 & 62,9 & 8 & 684,2 & 207,1 \\
\hline
\end{tabular}


Área 2B

Biomassa: 5,0 T/ha.

Área basal média: 1,66 m2/ha.

28 árvores/ha.

\begin{tabular}{|c|c|c|c|c|c|}
\hline Quadr. & Indivíduo & Dist. (m) & Alt. (m) & $\mathrm{AB}\left(\mathrm{cm}^{2}\right)$ & Biomassa $(\mathrm{kg})$ \\
\hline \multirow{4}{*}{1} & 1 & 10,7 & 5 & 175,8 & 33,5 \\
\hline & 2 & 34,4 & 10 & 1838,6 & 693,0 \\
\hline & 3 & 6,9 & 4,5 & 108,9 & 18,7 \\
\hline & 4 & 14,4 & 5 & 207,0 & 39,4 \\
\hline \multirow{4}{*}{2} & 1 & 33,2 & 4 & 127,3 & 19,4 \\
\hline & 2 & 11,5 & 6 & 267,7 & 61,0 \\
\hline & 3 & 11,3 & 4,5 & 325,9 & 55,7 \\
\hline & 4 & 31,5 & 8 & 1032,8 & 312,2 \\
\hline \multirow{4}{*}{3} & 1 & 21,6 & 11 & 258,5 & 107,9 \\
\hline & 2 & 12,6 & 14 & 1034,2 & 546,1 \\
\hline & 3 & 11,9 & 10 & 1849,4 & 697,0 \\
\hline & 4 & 44 & 12 & 1559,7 & 705,4 \\
\hline \multirow{4}{*}{4} & 1 & 17,5 & 10 & 2675,8 & 1007,3 \\
\hline & 2 & 62 & 15 & 1814,4 & 1024,5 \\
\hline & 3 & 51 & 4,5 & 258,5 & 44,3 \\
\hline & 4 & 40,3 & 4,5 & 1549,8 & 263,7 \\
\hline \multirow{4}{*}{5} & 1 & 10 & 6 & 652,4 & 148,3 \\
\hline & 2 & 47 & 5 & 315,8 & 60,0 \\
\hline & 3 & 63,4 & 3,5 & 215,2 & 28,7 \\
\hline & 4 & 84,8 & 12 & 2037,2 & 920,5 \\
\hline \multirow{4}{*}{6} & 1 & 0,3 & 5 & 240,7 & 45,8 \\
\hline & 2 & 0,9 & 4 & 154,1 & 23,5 \\
\hline & 3 & 1,2 & 5 & 267,7 & 50,9 \\
\hline & 4 & 1,6 & 4,5 & 232,0 & 39,7 \\
\hline \multirow{4}{*}{7} & 1 & 27,7 & 6 & 424,1 & 96,5 \\
\hline & 2 & 13,63 & 4,5 & 412,5 & 70,5 \\
\hline & 3 & 9,45 & 10 & 1650,1 & 622,2 \\
\hline & 4 & 17,9 & 9 & 814,9 & 277,3 \\
\hline \multirow{4}{*}{8} & 1 & 6,9 & 5 & 168,4 & 32,1 \\
\hline & 2 & 10,2 & 4,5 & 147,1 & 25,2 \\
\hline & 3 & 16,88 & 8 & 357,2 & 108,4 \\
\hline & 4 & 41 & 12 & 4032,9 & 1818,2 \\
\hline \multirow{4}{*}{9} & 1 & 17,55 & 4,5 & 551,1 & 94,1 \\
\hline & 2 & 29,2 & 4 & 509,3 & 77,3 \\
\hline & 3 & 38,3 & 6 & 258,5 & 58,9 \\
\hline & 4 & 37,4 & 4 & 235,5 & 35,9 \\
\hline \multirow{4}{*}{10} & 1 & 15,4 & 6 & 198,9 & 45,4 \\
\hline & 2 & 20,1 & 5 & 191,1 & 36,4 \\
\hline & 3 & 9,3 & 6 & 405,7 & 92,4 \\
\hline & 4 & 8,1 & 4,5 & 336,2 & 57,5 \\
\hline \multirow[t]{2}{*}{11} & 1 & 4 & 5 & 522,1 & 99,0 \\
\hline & 2 & 1,1 & 3,5 & 346,6 & 46,1 \\
\hline
\end{tabular}




\begin{tabular}{|c|c|c|c|c|c|}
\hline Quadr. & Indivíduo & Dist. (m) & Alt. (m) & $\mathrm{AB}\left(\mathrm{cm}^{2}\right)$ & Biomassa $(\mathrm{kg})$ \\
\hline & 3 & 40,5 & 3,5 & 223,5 & 29,8 \\
\hline & 4 & 8 & 4 & 207,0 & 31,5 \\
\hline \multirow{4}{*}{12} & 1 & 3,7 & 3,5 & 97,5 & 13,0 \\
\hline & 2 & 4,7 & 4,5 & 435,8 & 74,5 \\
\hline & 3 & 5,1 & 4 & 406,9 & 61,8 \\
\hline & 4 & 8,1 & 3,5 & 232,0 & 30,9 \\
\hline \multirow{4}{*}{13} & 1 & 18,4 & 4 & 183,3 & 27,9 \\
\hline & 2 & 14,4 & 6 & 191,1 & 43,6 \\
\hline & 3 & 4,9 & 5 & 893,2 & 169,1 \\
\hline & 4 & 25,9 & 8 & 1273,6 & 384,8 \\
\hline \multirow{4}{*}{14} & 1 & 15,6 & 6 & 342,5 & 78,0 \\
\hline & 2 & 3,6 & 3,5 & 212,4 & 28,3 \\
\hline & 3 & 22,4 & 4 & 240,7 & 36,6 \\
\hline & 4 & 19 & 4,5 & 644,6 & 110,0 \\
\hline \multirow{4}{*}{15} & 1 & 12,3 & 7 & 660,4 & 175,0 \\
\hline & 2 & 6,5 & 4,5 & 372,8 & 63,7 \\
\hline & 3 & 5,6 & 5 & 583,0 & 110,5 \\
\hline & 4 & 20,2 & 6 & 356,0 & 81,1 \\
\hline \multirow{4}{*}{16} & 1 & 11 & 8 & 389,9 & 118,3 \\
\hline & 2 & 5,4 & 3,5 & 416,5 & 55,4 \\
\hline & 3 & 11,7 & 4 & 198,9 & 30,3 \\
\hline & 4 & 8,6 & 8 & 325,9 & 98,9 \\
\hline \multirow{4}{*}{17} & 1 & 21 & 9 & 286,5 & 97,8 \\
\hline & 2 & 8,9 & 5 & 374,5 & 71,1 \\
\hline & 3 & 16,9 & 6 & 175,8 & 40,1 \\
\hline & 4 & 11,6 & 6 & 240,7 & 54,9 \\
\hline \multirow{4}{*}{18} & 1 & 7,5 & 6 & 258,5 & 58,9 \\
\hline & 2 & 5,6 & 6 & 389,9 & 88,8 \\
\hline & 3 & 5,2 & 4,5 & 175,8 & 30,1 \\
\hline & 4 & 7,9 & 5 & 368,0 & 69,9 \\
\hline \multirow{4}{*}{19} & 1 & 17,9 & 6 & 325,9 & 74,3 \\
\hline & 2 & 6,7 & 6 & 795,8 & 180,8 \\
\hline & 3 & 30,4 & 5,5 & 438,7 & 91,6 \\
\hline & 4 & 61 & 6 & 675,3 & 153,5 \\
\hline \multirow{4}{*}{20} & 1 & 7,4 & 4 & 240,7 & 36,6 \\
\hline & 2 & 14,9 & 4 & 258,5 & 39,4 \\
\hline & 3 & 8 & 8 & 2003,8 & 604,5 \\
\hline & 4 & 50,7 & 7 & 368,1 & 97,8 \\
\hline
\end{tabular}


Área 3B

6,9 T/ha.

Área basal média: $2,7 \mathrm{~m}^{2} / \mathrm{ha}$.

79,9 árvores/ha.

\begin{tabular}{|c|c|c|c|c|c|}
\hline Quadr. & Indivíduo & Dist. (m) & Alt. (m) & $\mathrm{AB}\left(\mathrm{cm}^{2}\right)$ & Biomassa(Kg \\
\hline \multirow{4}{*}{1} & 1 & 5,05 & 8 & 1557,9 & 470,3 \\
\hline & 2 & 5,6 & 6 & 407,5 & 92,8 \\
\hline & 3 & 18 & 7,5 & 795,8 & 225,8 \\
\hline & 4 & 16 & 6 & 286,5 & 65,3 \\
\hline \multirow{4}{*}{2} & 1 & 20 & 4 & 286,5 & 43,6 \\
\hline & 2 & 15 & 3,5 & 49,7 & 6,7 \\
\hline & 3 & 16 & 5 & 718,2 & 136,1 \\
\hline & 4 & 18 & 4,5 & 53,6 & 9,2 \\
\hline \multirow{4}{*}{3} & 1 & 16 & 6,5 & 127,3 & 31,5 \\
\hline & 2 & 15 & 6,5 & 512,0 & 126,1 \\
\hline & 3 & 14 & 5,5 & 191,1 & 40,0 \\
\hline & 4 & 12 & 4 & 60,0 & 9,2 \\
\hline \multirow{4}{*}{4} & 1 & 11 & 3,5 & 207,0 & 27,6 \\
\hline & 2 & 25 & 8 & 811,8 & 245,6 \\
\hline & 3 & 24 & 3,5 & 37,2 & 5,0 \\
\hline & 4 & 30 & 3,5 & 154,1 & 20,6 \\
\hline \multirow{4}{*}{5} & 1 & 7 & 5 & 459,6 & 87,2 \\
\hline & 2 & 7 & 6 & 346,6 & 79,0 \\
\hline & 3 & 2,5 & 6 & 92,0 & 21,0 \\
\hline & 4 & 6 & 10 & 183,3 & 69,6 \\
\hline \multirow{4}{*}{6} & 1 & 13 & 7 & 522,1 & 138,5 \\
\hline & 2 & 4 & 6,5 & 161,1 & 39,9 \\
\hline & 3 & 12 & 4,5 & 23,0 & 4,0 \\
\hline & 4 & 20 & 7 & 471,8 & 125,2 \\
\hline \multirow{4}{*}{7} & 1 & 8 & 5,5 & 240,7 & 50,3 \\
\hline & 2 & 17 & 4 & 35,1 & 5,4 \\
\hline & 3 & 16 & 7 & 218,5 & 58,1 \\
\hline & 4 & 18 & 4 & 114,9 & 17,5 \\
\hline \multirow{4}{*}{8} & 1 & 8 & 5 & 267,7 & 50,9 \\
\hline & 2 & 9 & 3,5 & 108,9 & 14,6 \\
\hline & 3 & 4 & 5 & 297,5 & 56,5 \\
\hline & 4 & 15 & 3,5 & 114,9 & 15,4 \\
\hline \multirow{4}{*}{9} & 1 & 11 & 6 & 201,6 & 46,0 \\
\hline & 2 & 13 & 4 & 207,0 & 31,5 \\
\hline & 3 & 14 & 6 & 127,3 & 29,1 \\
\hline & 4 & 17 & 4,5 & 375,4 & 64,2 \\
\hline \multirow{4}{*}{10} & 1 & 4 & 3 & 23,0 & 2,6 \\
\hline & 2 & 8 & 6 & 223,5 & 51,0 \\
\hline & 3 & 12 & 5 & 189,8 & 36,1 \\
\hline & 4 & 12 & 4 & 53,8 & 8,2 \\
\hline
\end{tabular}




\begin{tabular}{|c|c|c|c|c|c|}
\hline Quadr. & Indivíduo & Dist. (m) & Alt. (m) & $\mathrm{AB}\left(\mathrm{cm}^{2}\right)$ & Biomassa(Kg \\
\hline \multirow{4}{*}{11} & 1 & 5 & 3,5 & 499,3 & 66,4 \\
\hline & 2 & 25 & 3,5 & 175,8 & 23,5 \\
\hline & 3 & 7 & 5 & 133,8 & 25,5 \\
\hline & 4 & 4 & 4 & 175,8 & 26,8 \\
\hline \multirow{4}{*}{12} & 1 & 6 & 4,5 & 389,9 & 66,6 \\
\hline & 2 & 8 & 4 & 215,2 & 32,8 \\
\hline & 3 & 3 & 12 & 140,4 & 64,0 \\
\hline & 4 & 16 & 8 & 1790,5 & 540,3 \\
\hline \multirow{4}{*}{13} & 1 & 1,6 & 4,5 & 140,4 & 24,1 \\
\hline & 2 & 5 & 4 & 302,1 & 46,0 \\
\hline & 3 & 8 & 4,5 & 161,1 & 27,6 \\
\hline & 4 & 10 & 3,5 & 66,9 & 9,0 \\
\hline \multirow{4}{*}{14} & 1 & 4,5 & 5 & 249,6 & 47,4 \\
\hline & 2 & 3,5 & 3 & 169,1 & 19,3 \\
\hline & 3 & 7 & 3,5 & 81,5 & 10,9 \\
\hline & 4 & 12 & 3 & 133,8 & 15,3 \\
\hline \multirow{4}{*}{15} & 1 & 11 & 6 & 354,1 & 80,7 \\
\hline & 2 & 2,5 & 4 & 522,0 & 79,3 \\
\hline & 3 & 1,4 & 5 & 161,1 & 30,7 \\
\hline & 4 & 6 & 3,5 & 198,9 & 26,5 \\
\hline \multirow{4}{*}{16} & 1 & 4 & 12 & 3509,4 & 1582,9 \\
\hline & 2 & 15 & 4 & 325,9 & 49,6 \\
\hline & 3 & 13 & 5 & 198,9 & 37,9 \\
\hline & 4 & 16 & 4 & 286,5 & 43,6 \\
\hline \multirow{4}{*}{17} & 1 & 5 & 5 & 557,3 & 105,7 \\
\hline & 2 & 14 & 5 & 482,9 & 91,6 \\
\hline & 3 & 9 & 4 & 178,9 & 27,3 \\
\hline & 4 & 13 & 4 & 42,1 & 6,4 \\
\hline \multirow{4}{*}{18} & 1 & 3,5 & 4 & 81,5 & 12,4 \\
\hline & 2 & 10 & 8 & 764,3 & 231,3 \\
\hline & 3 & 6 & 6 & 403,0 & 91,7 \\
\hline & 4 & 11 & 3,5 & 92,0 & 12,3 \\
\hline \multirow{4}{*}{19} & 1 & 12 & 6 & 277,0 & 63,1 \\
\hline & 2 & 12 & 8 & 471,8 & 143,0 \\
\hline & 3 & 17 & 4,5 & 71,6 & 12,3 \\
\hline & 4 & 18 & 6 & 183,3 & 41,8 \\
\hline \multirow{4}{*}{20} & 1 & 17 & 4,5 & 97,5 & 16,7 \\
\hline & 2 & 8 & 3,5 & 239,2 & 31,9 \\
\hline & 3 & 5,8 & 7 & 962,9 & 254,9 \\
\hline & 4 & 21 & 5 & 459,6 & 87,2 \\
\hline
\end{tabular}


Área 4B

33,4 T/ha.

Área basal média: $11,9 \mathrm{~m}^{2} /$ ha.

889,4 árvores/ha.

\begin{tabular}{|c|c|c|c|c|c|}
\hline Quadr & Indivíduo & Dist. (m) & Alt. (m) & $\mathrm{AB}\left(\mathrm{cm}^{2}\right)$ & Biomassa $(\mathrm{kg})$ \\
\hline \multirow{4}{*}{1} & 1 & 3 & 8 & 66,9 & 20,4 \\
\hline & 2 & 2,5 & 4 & 28,7 & 4,4 \\
\hline & 3 & 4 & 9 & 154,1 & 52,7 \\
\hline & 4 & 3 & 7 & 53,8 & 14,4 \\
\hline \multirow{4}{*}{2} & 1 & 1,5 & 8 & 140,4 & 42,7 \\
\hline & 2 & 4 & 7 & 169,1 & 45,0 \\
\hline & 3 & 2 & 7 & 76,5 & 20,4 \\
\hline & 4 & 1,5 & 9 & 240,7 & 82,2 \\
\hline \multirow{4}{*}{3} & 1 & 1 & 8 & 336,2 & 102,0 \\
\hline & 2 & 2 & 10 & 561,5 & 212,5 \\
\hline & 3 & 1 & 6 & 108,9 & 24,9 \\
\hline & 4 & 8 & 6 & 62,4 & 14,3 \\
\hline \multirow{4}{*}{4} & 1 & 3 & 7 & 129,3 & 34,5 \\
\hline & 2 & 10 & 8 & 252,3 & 76,6 \\
\hline & 3 & 6 & 6 & 58,0 & 13,3 \\
\hline & 4 & 5 & 4,5 & 49,7 & 8,6 \\
\hline \multirow{4}{*}{5} & 1 & 1,5 & 8 & 429,2 & 130,1 \\
\hline & 2 & 1,3 & 7 & 81,5 & 21,7 \\
\hline & 3 & 1,2 & 7 & 86,7 & 23,1 \\
\hline & 4 & 4 & 5 & 35,1 & 6,7 \\
\hline \multirow{4}{*}{6} & 1 & 2,5 & 8 & 140,4 & 42,7 \\
\hline & 2 & 0,3 & 4,5 & 45,8 & 7,9 \\
\hline & 3 & 4 & 8 & 133,8 & 40,7 \\
\hline & 4 & 6 & 7 & 491,8 & 130,5 \\
\hline \multirow{4}{*}{7} & 1 & 1 & 7 & 224,5 & 59,7 \\
\hline & 2 & 4 & 7 & 62,4 & 16,7 \\
\hline & 3 & 1,2 & 4 & 62,4 & 9,5 \\
\hline & 4 & 4,5 & 5 & 23,0 & 4,4 \\
\hline \multirow{4}{*}{8} & 1 & 0,5 & 5 & 23,0 & 4,4 \\
\hline & 2 & 3,5 & 8 & 277,0 & 84,1 \\
\hline & 3 & 3 & 8 & 396,4 & 120,2 \\
\hline & 4 & 2,5 & 6 & 158,9 & 36,3 \\
\hline \multirow{4}{*}{9} & 1 & 3 & 5 & 35,1 & 6,7 \\
\hline & 2 & 3 & 5 & 62,4 & 11,9 \\
\hline & 3 & 2,5 & 5 & 38,5 & 7,4 \\
\hline & 4 & 4 & 5 & 31,8 & 6,1 \\
\hline \multirow{4}{*}{10} & 1 & 7 & 5 & 718,6 & 136,1 \\
\hline & 2 & 4,5 & 5 & 95,6 & 18,2 \\
\hline & 3 & 4 & 6 & 23,0 & 5,3 \\
\hline & 4 & 6 & 4,5 & 17,9 & 3,1 \\
\hline
\end{tabular}




\begin{tabular}{|c|c|c|c|c|c|}
\hline Quadr & Indivíduo & Dist. (m) & Alt. (m) & $\mathrm{AB}\left(\mathrm{cm}^{2}\right)$ & Biomassa $(\mathrm{kg})$ \\
\hline \multirow{4}{*}{11} & 1 & 2 & 3,5 & 114,9 & 15,4 \\
\hline & 2 & 3 & 7 & 81,5 & 21,7 \\
\hline & 3 & 1,5 & 4 & 62,4 & 9,5 \\
\hline & 4 & 2,5 & 10 & 183,3 & 69,6 \\
\hline \multirow{4}{*}{12} & 1 & 4,5 & 10 & 472,8 & 179,0 \\
\hline & 2 & 5 & 5 & 35,1 & 6,7 \\
\hline & 3 & 3 & 3 & 86,7 & 9,9 \\
\hline & 4 & 4,5 & 10 & 554,3 & 209,8 \\
\hline \multirow{4}{*}{13} & 1 & 4 & 10 & 497,4 & 188,3 \\
\hline & 2 & 8 & 10 & 127,3 & 48,4 \\
\hline & 3 & 5 & 4,5 & 25,8 & 4,4 \\
\hline & 4 & 6 & 7 & 111,6 & 29,7 \\
\hline \multirow{4}{*}{14} & 1 & 4 & 7 & 322,1 & 85,6 \\
\hline & 2 & 4,5 & 2 & 45,8 & 3,5 \\
\hline & 3 & 6,5 & 7 & 286,5 & 76,1 \\
\hline & 4 & 2 & 7 & 52,2 & 14,0 \\
\hline \multirow{4}{*}{15} & 1 & 1 & 6,5 & 236,9 & 58,5 \\
\hline & 2 & 5 & 6 & 53,8 & 12,3 \\
\hline & 3 & 6 & 3,5 & 35,1 & 4,7 \\
\hline & 4 & 3 & 3 & 17,9 & 2,1 \\
\hline \multirow{4}{*}{16} & 1 & 1 & 3,5 & 25,8 & 3,5 \\
\hline & 2 & 0,65 & 3,5 & 23,0 & 3,1 \\
\hline & 3 & 0,6 & 4 & 23,0 & 3,5 \\
\hline & 4 & 1,5 & 9 & 42,1 & 14,5 \\
\hline \multirow{4}{*}{17} & 1 & 5 & 7 & 175,8 & 46,8 \\
\hline & 2 & 3 & 4,5 & 25,8 & 4,4 \\
\hline & 3 & 6 & 5 & 76,5 & 14,6 \\
\hline & 4 & 2,5 & 7 & 23,0 & 6,2 \\
\hline \multirow{4}{*}{18} & 1 & 4 & 8 & 58,0 & 17,7 \\
\hline & 2 & 0,5 & 6 & 62,4 & 14,3 \\
\hline & 3 & 7 & 12 & 31,8 & 14,6 \\
\hline & 4 & 2,5 & 5 & 305,9 & 58,1 \\
\hline \multirow{4}{*}{19} & 1 & 3 & 5 & 17,9 & 3,4 \\
\hline & 2 & 3 & 5 & 31,8 & 6,1 \\
\hline & 3 & 3 & 7 & 23,0 & 6,2 \\
\hline & 4 & 2,5 & 7 & 49,7 & 13,3 \\
\hline \multirow{4}{*}{20} & 1 & 2,5 & 7 & 20,4 & 5,5 \\
\hline & 2 & 0,5 & 5 & 49,7 & 9,5 \\
\hline & 3 & 2,5 & 6 & 17,9 & 4,1 \\
\hline & 4 & 3,5 & 6 & 23,0 & 5,3 \\
\hline
\end{tabular}




\section{Área 5B}

Biomassa: 57,7 T/ha.

Área basal média: $20,11 \mathrm{~m}^{2} /$ ha.

910,7 árvores/ha.

\begin{tabular}{|c|c|c|c|c|c|}
\hline Quadr & Indivíduo & Dist. (m) & Alt. $(\mathrm{m})$ & $A B\left(\mathrm{~cm}^{2}\right)$ & Biomassa $(\mathrm{kg})$ \\
\hline \multirow{4}{*}{1} & 1 & 3 & 8 & 168,4 & 51,2 \\
\hline & 2 & 5 & 8 & 962,9 & 291,2 \\
\hline & 3 & 5 & 6 & 223,5 & 51,0 \\
\hline & 4 & 10 & 7 & 1559,7 & 412,2 \\
\hline \multirow{4}{*}{2} & 1 & 2 & 8 & 860,7 & 260,4 \\
\hline & 2 & 7 & 7 & 232,0 & 61,7 \\
\hline & 3 & 2 & 7 & 191,1 & 50,8 \\
\hline & 4 & 5 & 4,5 & 25,8 & 4,4 \\
\hline \multirow{4}{*}{3} & 1 & 1,5 & 4 & 38,5 & 5,9 \\
\hline & 2 & 4 & 4,5 & 58,0 & 10,0 \\
\hline & 3 & 5 & 4,5 & 38,5 & 6,6 \\
\hline & 4 & 4 & 4,5 & 76,5 & 13,1 \\
\hline \multirow{4}{*}{4} & 1 & 1,2 & 6 & 482,1 & 109,7 \\
\hline & 2 & 2,5 & 5 & 42,1 & 8,1 \\
\hline & 3 & 5 & 8 & 962,9 & 291,2 \\
\hline & 4 & 5 & 4,5 & 108,9 & 18,7 \\
\hline \multirow{4}{*}{5} & 1 & 4 & 7 & 104,5 & 27,9 \\
\hline & 2 & 2,5 & 8 & 1018,6 & 308,0 \\
\hline & 3 & 4 & 7 & 140,4 & 37,4 \\
\hline & 4 & 3 & 9 & 435,8 & 148,6 \\
\hline \multirow{4}{*}{6} & 1 & 1,5 & 8 & 631,0 & 191,1 \\
\hline & 2 & 3 & 7 & 360,1 & 95,6 \\
\hline & 3 & 5 & 6,5 & 191,1 & 47,2 \\
\hline & 4 & 4,5 & 6,5 & 66,9 & 16,6 \\
\hline \multirow{4}{*}{7} & 1 & 6 & 4,5 & 31,8 & 5,5 \\
\hline & 2 & 4 & 7 & 147,1 & 39,2 \\
\hline & 3 & 3 & 9 & 616,2 & 209,9 \\
\hline & 4 & 2,5 & 7 & 66,9 & 17,9 \\
\hline \multirow{4}{*}{8} & 1 & 3,5 & 6 & 53,8 & 12,3 \\
\hline & 2 & 12 & 7 & 127,3 & 33,9 \\
\hline & 3 & 2,5 & 6 & 86,7 & 19,8 \\
\hline & 4 & 2,5 & 3,5 & 31,8 & 4,3 \\
\hline \multirow{4}{*}{9} & 1 & 4 & 8 & 412,5 & 125,1 \\
\hline & 2 & 2,5 & 4 & 25,8 & 4,0 \\
\hline & 3 & 2 & 5 & 71,6 & 13,7 \\
\hline & 4 & 3 & 5 & 38,5 & 7,4 \\
\hline \multirow{4}{*}{10} & 1 & 2 & 6 & 71,6 & 16,4 \\
\hline & 2 & 5 & 9 & 435,8 & 148,6 \\
\hline & 3 & 6 & 8 & 154,1 & 46,9 \\
\hline & 4 & 5 & 5 & 38,5 & 7,4 \\
\hline
\end{tabular}




\begin{tabular}{|c|c|c|c|c|c|}
\hline Quadr & Indivíduo & Dist. (m) & Alt. (m) & $\mathrm{AB}\left(\mathrm{cm}^{2}\right)$ & Biomassa $(\mathrm{kg})$ \\
\hline \multirow{4}{*}{11} & 1 & 3 & 4 & 41,4 & 6,3 \\
\hline & 2 & 6 & 5 & 28,7 & 5,5 \\
\hline & 3 & 2,5 & 4,5 & 114,9 & 19,7 \\
\hline & 4 & 4 & 10 & 1451,9 & 547,6 \\
\hline \multirow{4}{*}{12} & 1 & 3 & 4,5 & 62,4 & 10,7 \\
\hline & 2 & 2,5 & 7 & 97,5 & 26,0 \\
\hline & 3 & 3 & 4,5 & 31,8 & 5,5 \\
\hline & 4 & 4 & 8 & 66,9 & 20,4 \\
\hline \multirow{4}{*}{13} & 1 & 1,2 & 10 & 644,6 & 243,8 \\
\hline & 2 & 2,5 & 3 & 31,8 & 3,7 \\
\hline & 3 & 2,5 & 4 & 35,1 & 5,4 \\
\hline & 4 & 1,5 & 5 & 20,4 & 3,9 \\
\hline \multirow{4}{*}{14} & 1 & 1,2 & 8 & 108,9 & 33,2 \\
\hline & 2 & 0,75 & 7 & 49,7 & 13,3 \\
\hline & 3 & 4 & 7 & 147,1 & 39,2 \\
\hline & 4 & 2,5 & 7 & 97,5 & 26,0 \\
\hline \multirow{4}{*}{15} & 1 & 1 & 7 & 23,0 & 6,2 \\
\hline & 2 & 0,85 & 7 & 267,7 & 71,2 \\
\hline & 3 & 1,3 & 7 & 179,0 & 47,6 \\
\hline & 4 & 3 & 6,5 & 267,7 & 66,1 \\
\hline \multirow{4}{*}{16} & 1 & 3 & 4,5 & 28,7 & 5,0 \\
\hline & 2 & 1,8 & 5 & 91,5 & 17,5 \\
\hline & 3 & 3 & 5 & 86,7 & 16,5 \\
\hline & 4 & 1,1 & 7 & 97,1 & 25,9 \\
\hline \multirow{4}{*}{17} & 1 & 6 & 7 & 198,9 & 52,9 \\
\hline & 2 & 2 & 7 & 183,3 & 48,8 \\
\hline & 3 & 1,1 & 8 & 207,0 & 62,9 \\
\hline & 4 & 3 & 3,5 & 154,1 & 20,6 \\
\hline \multirow{4}{*}{18} & 1 & 0,5 & 10 & 267,7 & 101,5 \\
\hline & 2 & 3 & 5 & 23,0 & 4,4 \\
\hline & 3 & 3,5 & 7,5 & 45,8 & 13,1 \\
\hline & 4 & 3 & 5 & 20,4 & 3,9 \\
\hline \multirow{4}{*}{19} & 1 & 1,1 & 5 & 315,8 & 60,0 \\
\hline & 2 & 5 & 4,5 & 35,1 & 6,0 \\
\hline & 3 & 4 & 4,5 & 23,0 & 4,0 \\
\hline & 4 & 3 & 8 & 133,8 & 40,7 \\
\hline \multirow{4}{*}{20} & 1 & 2,5 & 4,5 & 58,0 & 10,0 \\
\hline & 2 & 3 & 7 & 325,9 & 86,6 \\
\hline & 3 & 2,5 & 8 & 175,8 & 53,5 \\
\hline & 4 & 2,5 & 3,5 & 38,5 & 5,2 \\
\hline
\end{tabular}


Área 6B

Biomassa: 62,7 T/ha.

Área basal média: $17,6 \mathrm{~m}^{2} / \mathrm{ha}$.

983 árvores/ha.

\begin{tabular}{|c|c|c|c|c|c|}
\hline Quadr & Indivíduo & Dist. (m) & Alt. (m) & $\mathrm{AB}\left(\mathrm{cm}^{2}\right)$ & BiomassaT/ha \\
\hline \multirow{4}{*}{1} & 1 & 5 & 8 & 92,0 & 28,0 \\
\hline & 2 & 1 & 12 & 258,5 & 117,6 \\
\hline & 3 & 0,5 & 7 & 100,9 & 26,9 \\
\hline & 4 & 3 & 8 & 154,1 & 46,9 \\
\hline \multirow{4}{*}{2} & 1 & 3 & 10 & 97,5 & 37,1 \\
\hline & 2 & 2,5 & 7 & 31,8 & 8,5 \\
\hline & 3 & 3,5 & 7 & 71,6 & 19,1 \\
\hline & 4 & 3,5 & 9 & 190,4 & 65,1 \\
\hline \multirow{4}{*}{3} & 1 & 2 & 7 & 42,1 & 11,3 \\
\hline & 2 & 3 & 8 & 95,6 & 29,1 \\
\hline & 3 & 2,5 & 11 & 258,5 & 107,9 \\
\hline & 4 & 2,5 & 8 & 49,7 & 15,2 \\
\hline \multirow{4}{*}{4} & 1 & 3 & 7 & 121,0 & 32,3 \\
\hline & 2 & 3,5 & 9 & 35,1 & 12,1 \\
\hline & 3 & 1,5 & 12 & 258,5 & 117,6 \\
\hline & 4 & 4 & 12 & 498,9 & 226,5 \\
\hline \multirow{4}{*}{5} & 1 & 3,5 & 9 & 237,9 & 81,3 \\
\hline & 2 & 0,8 & 7 & 76,5 & 20,4 \\
\hline & 3 & 1 & 5 & 23,0 & 4,4 \\
\hline & 4 & 1,2 & 8 & 42,1 & 12,9 \\
\hline \multirow{4}{*}{6} & 1 & 1 & 7 & 81,5 & 21,7 \\
\hline & 2 & 2 & 10 & 175,8 & 66,8 \\
\hline & 3 & 0,7 & 8 & 127,3 & 38,8 \\
\hline & 4 & 3 & 7 & 20,4 & 5,5 \\
\hline \multirow{4}{*}{7} & 1 & 3 & 5 & 108,9 & 20,8 \\
\hline & 2 & 4 & 13 & 296,1 & 145,8 \\
\hline & 3 & 3 & 15 & 368,0 & 208,9 \\
\hline & 4 & 1,5 & 8 & 161,1 & 49,0 \\
\hline \multirow{4}{*}{8} & 1 & 2 & 7 & 121,0 & 32,3 \\
\hline & 2 & 0,5 & 12 & 183,3 & 83,5 \\
\hline & 3 & 4 & 9 & 58,0 & 19,9 \\
\hline & 4 & 3 & 8 & 81,5 & 24,8 \\
\hline \multirow{4}{*}{9} & 1 & 10 & 14 & 484,1 & 256,3 \\
\hline & 2 & 5 & 8 & 302,9 & 91,9 \\
\hline & 3 & 2,5 & 8 & 97,5 & 29,7 \\
\hline & 4 & 3 & 7 & 66,9 & 17,9 \\
\hline \multirow{4}{*}{10} & 1 & 2 & 8 & 240,7 & 73,1 \\
\hline & 2 & 2,5 & 7 & 403,6 & 107,1 \\
\hline & 3 & 2,5 & 4,5 & 108,9 & 18,7 \\
\hline & 4 & 2 & 8 & 389,9 & 118,3 \\
\hline
\end{tabular}




\begin{tabular}{|c|c|c|c|c|c|}
\hline Quadr & Indivíduo & Dist. (m) & Alt. (m) & $\mathrm{AB}\left(\mathrm{cm}^{2}\right)$ & BiomassaT/ha \\
\hline \multirow{4}{*}{11} & 1 & 1,5 & 14 & 795,8 & 420,6 \\
\hline & 2 & 3 & 8 & 644,6 & 195,2 \\
\hline & 3 & 1,5 & 5 & 28,7 & 5,5 \\
\hline & 4 & 10 & 4,5 & 31,8 & 5,5 \\
\hline \multirow{4}{*}{12} & 1 & 6 & 7 & 71,6 & 19,1 \\
\hline & 2 & 5 & 4,5 & 97,5 & 16,7 \\
\hline & 3 & 7 & 7 & 49,7 & 13,3 \\
\hline & 4 & 10 & 12 & 408,1 & 185,4 \\
\hline \multirow{4}{*}{13} & 1 & 2 & 9 & 225,5 & 77,1 \\
\hline & 2 & 1,5 & 9 & 175,8 & 60,1 \\
\hline & 3 & 3 & 4,5 & 42,1 & 7,2 \\
\hline & 4 & 5 & 8 & 509,3 & 154,3 \\
\hline \multirow{4}{*}{14} & 1 & 3 & 4 & 28,7 & 4,4 \\
\hline & 2 & 7 & 6 & 71,6 & 16,4 \\
\hline & 3 & 2,5 & 8 & 296,1 & 89,9 \\
\hline & 4 & 5 & 8 & 357,8 & 108,5 \\
\hline \multirow{4}{*}{15} & 1 & 5 & 8 & 140,4 & 42,7 \\
\hline & 2 & 4 & 7 & 140,4 & 37,4 \\
\hline & 3 & 4,5 & 6 & 290,7 & 66,3 \\
\hline & 4 & 6 & 10 & 535,1 & 202,5 \\
\hline \multirow{4}{*}{16} & 1 & 5 & 6 & 376,3 & 85,7 \\
\hline & 2 & 1,5 & 8 & 25,8 & 7,9 \\
\hline & 3 & 3 & 7 & 97,5 & 26,0 \\
\hline & 4 & 1,5 & 7 & 644,6 & 170,8 \\
\hline \multirow{4}{*}{17} & 1 & 4 & 8 & 45,8 & 14,0 \\
\hline & 2 & 3 & 9 & 140,4 & 48,0 \\
\hline & 3 & 2,5 & 10 & 108,9 & 41,4 \\
\hline & 4 & 4,5 & 12 & 305,9 & 139,1 \\
\hline \multirow{4}{*}{18} & 1 & 2 & 6 & 45,8 & 10,5 \\
\hline & 2 & 0,5 & 6 & 62,4 & 14,3 \\
\hline & 3 & 4 & 6 & 31,8 & 7,3 \\
\hline & 4 & 3,5 & 13 & 114,9 & 56,8 \\
\hline \multirow{4}{*}{19} & 1 & 0,7 & 7 & 38,5 & 10,3 \\
\hline & 2 & 6 & 12 & 121,0 & 55,2 \\
\hline & 3 & 2,5 & 12 & 198,9 & 90,6 \\
\hline & 4 & 1,2 & 6 & 28,7 & 6,6 \\
\hline \multirow{4}{*}{20} & 1 & 3 & 12 & 183,3 & 83,5 \\
\hline & 2 & 3 & 8 & 77,7 & 23,7 \\
\hline & 3 & 2,5 & 4 & 53,8 & 8,2 \\
\hline & 4 & 1 & 8 & 62,4 & 19,0 \\
\hline
\end{tabular}




\section{Área 7B}

Biomassa: 72,2 T/ha.

Área basal média: $20,11 \mathrm{~m}^{2} /$ ha.

793,4 árvores/ha.

\begin{tabular}{|c|c|c|c|c|c|}
\hline Quadr & Indivíduo & Dist. (m) & Alt. $(\mathrm{m})$ & $A B\left(\mathrm{~cm}^{2}\right)$ & Biomassa $(\mathrm{kg})$ \\
\hline \multirow{4}{*}{1} & 1 & 2,8 & 8 & 232,0 & 70,5 \\
\hline & 2 & 3,4 & 7 & 121,0 & 32,3 \\
\hline & 3 & 3,1 & 10 & 703,1 & 265,9 \\
\hline & 4 & 10,4 & 9 & 114,9 & 39,4 \\
\hline \multirow{4}{*}{2} & 1 & 7,7 & 5 & 114,9 & 21,9 \\
\hline & 2 & 3,6 & 8 & 97,5 & 29,7 \\
\hline & 3 & 3 & 8 & 92,0 & 28,0 \\
\hline & 4 & 2,5 & 8 & 168,4 & 51,2 \\
\hline \multirow{4}{*}{3} & 1 & 2,6 & 7 & 258,5 & 68,7 \\
\hline & 2 & 6,8 & 8 & 435,8 & 132,1 \\
\hline & 3 & 3,5 & 9 & 389,9 & 133,0 \\
\hline & 4 & 3,3 & 7 & 76,5 & 20,4 \\
\hline \multirow{4}{*}{4} & 1 & 2,7 & 7 & 114,9 & 30,6 \\
\hline & 2 & 3,9 & 7 & 71,6 & 19,1 \\
\hline & 3 & 3,96 & 7 & 196,2 & 52,2 \\
\hline & 4 & 5,8 & 7 & 97,5 & 26,0 \\
\hline \multirow{4}{*}{5} & 1 & 3,7 & 7 & 140,4 & 37,4 \\
\hline & 2 & 2,4 & 6 & 97,5 & 22,3 \\
\hline & 3 & 1,15 & 8 & 198,9 & 60,5 \\
\hline & 4 & 2,4 & 8 & 154,1 & 46,9 \\
\hline \multirow{4}{*}{6} & 1 & 4,7 & 7 & 109,7 & 29,2 \\
\hline & 2 & 2,5 & 7 & 112,4 & 30,0 \\
\hline & 3 & 2,4 & 7 & 92,0 & 24,5 \\
\hline & 4 & 3,6 & 6 & 159,6 & 36,4 \\
\hline \multirow{4}{*}{7} & 1 & 0,85 & 8 & 198,9 & 60,5 \\
\hline & 2 & 5,5 & 10 & 286,5 & 108,6 \\
\hline & 3 & 1,7 & 6,5 & 318,3 & 78,5 \\
\hline & 4 & 5,3 & 10 & 315,8 & 119,7 \\
\hline \multirow{4}{*}{8} & 1 & 5,6 & 7 & 86,7 & 23,1 \\
\hline & 2 & 1,2 & 3,5 & 151,3 & 20,2 \\
\hline & 3 & 3,1 & 8 & 378,9 & 114,9 \\
\hline & 4 & 3,1 & 5 & 296,1 & 56,3 \\
\hline \multirow{4}{*}{9} & 1 & 1,3 & 5 & 92,0 & 17,5 \\
\hline & 2 & 2,5 & 6 & 147,1 & 33,6 \\
\hline & 3 & 2,8 & 6 & 207,0 & 47,2 \\
\hline & 4 & 8,5 & 7 & 118,5 & 31,6 \\
\hline \multirow{4}{*}{10} & 1 & 4,9 & 8 & 76,5 & 23,3 \\
\hline & 2 & 4 & 7 & 168,4 & 44,8 \\
\hline & 3 & 0,6 & 6 & 108,9 & 24,9 \\
\hline & 4 & 1,3 & 8 & 121,0 & 36,9 \\
\hline
\end{tabular}




\begin{tabular}{|c|c|c|c|c|c|}
\hline Quadr & Indivíduo & Dist. (m) & Alt. (m) & $\mathrm{AB}\left(\mathrm{cm}^{2}\right)$ & Biomassa $(\mathrm{kg})$ \\
\hline \multirow{4}{*}{11} & 1 & 0,75 & 6,5 & 97,5 & 24,1 \\
\hline & 2 & 4,5 & 7 & 82,8 & 22,1 \\
\hline & 3 & 2,3 & 7 & 92,0 & 24,5 \\
\hline & 4 & 3,3 & 7 & 121,0 & 32,3 \\
\hline \multirow{4}{*}{12} & 1 & 2,9 & 8 & 1060,4 & 320,5 \\
\hline & 2 & 2,7 & 8 & 211,4 & 64,2 \\
\hline & 3 & 7,3 & 8 & 127,3 & 38,8 \\
\hline & 4 & 6,6 & 10 & 412,5 & 156,3 \\
\hline \multirow{4}{*}{13} & 1 & 1,5 & 12 & 574,9 & 260,9 \\
\hline & 2 & 5,8 & 14 & 389,9 & 206,6 \\
\hline & 3 & 3,2 & 14 & 705,5 & 373,0 \\
\hline & 4 & 4,8 & 10 & 183,5 & 69,7 \\
\hline \multirow{4}{*}{14} & 1 & 2,5 & 15 & 758,9 & 429,7 \\
\hline & 2 & 4,7 & 8 & 133,8 & 40,7 \\
\hline & 3 & 2,9 & 10 & 147,1 & 55,9 \\
\hline & 4 & 3,6 & 15 & 1790,8 & 1011,2 \\
\hline \multirow{4}{*}{15} & 1 & 3,8 & 12 & 154,1 & 70,2 \\
\hline & 2 & 4,1 & 8 & 103,1 & 31,4 \\
\hline & 3 & 2,2 & 8 & 76,5 & 23,3 \\
\hline & 4 & 6,3 & 7 & 97,5 & 26,0 \\
\hline \multirow{4}{*}{16} & 1 & 1,4 & 7 & 71,6 & 19,1 \\
\hline & 2 & 2,2 & 8 & 198,9 & 60,5 \\
\hline & 3 & 3,6 & 10 & 154,1 & 58,5 \\
\hline & 4 & 4,5 & 8 & 97,5 & 29,7 \\
\hline \multirow{4}{*}{17} & 1 & 1,8 & 12 & 1181,0 & 534,6 \\
\hline & 2 & 2,5 & 7 & 305,9 & 81,3 \\
\hline & 3 & 4,5 & 8 & 583,1 & 176,6 \\
\hline & 4 & 6,3 & 8 & 232,0 & 70,5 \\
\hline \multirow{4}{*}{18} & 1 & 1,7 & 8 & 389,9 & 118,3 \\
\hline & 2 & 1,2 & 5 & 108,9 & 20,8 \\
\hline & 3 & 3,2 & 7 & 114,9 & 30,6 \\
\hline & 4 & 8,5 & 10 & 108,9 & 41,4 \\
\hline \multirow{4}{*}{19} & 1 & 1,7 & 7 & 76,5 & 20,4 \\
\hline & 2 & 1,7 & 7 & 127,3 & 33,9 \\
\hline & 3 & 2,2 & 8 & 147,1 & 44,8 \\
\hline & 4 & 2 & 8 & 703,1 & 212,8 \\
\hline \multirow{4}{*}{20} & 1 & 1,8 & 8 & 140,4 & 42,7 \\
\hline & 2 & 3,3 & 7 & 389,9 & 103,5 \\
\hline & 3 & 3,8 & 10 & 286,5 & 108,6 \\
\hline & 4 & 6,2 & 10 & 114,9 & 43,7 \\
\hline
\end{tabular}


Área 8B

Biomassa: 105,1 T/ha.

Área basal média: $27,34 \mathrm{~m}^{2} /$ ha.

2006 árvores/ha.

\begin{tabular}{|c|c|c|c|c|c|}
\hline Quadr & Indivíduo & Dist. (m) & Alt. $(\mathrm{m})$ & $A B\left(\mathrm{~cm}^{2}\right)$ & Biomassa $(\mathrm{kg})$ \\
\hline \multirow{4}{*}{1} & 1 & 1,1 & 4,5 & 31,8 & 17,2 \\
\hline & 2 & 3 & 4,5 & 45,8 & 20,6 \\
\hline & 3 & 1,5 & 4 & 23,0 & 13,0 \\
\hline & 4 & 3 & 4,5 & 66,9 & 24,9 \\
\hline \multirow{4}{*}{2} & 1 & 1,1 & 10 & 232,0 & 102,4 \\
\hline & 2 & 1,5 & 10 & 484,1 & 147,7 \\
\hline & 3 & 1,3 & 7 & 49,7 & 33,3 \\
\hline & 4 & 2 & 8 & 114,9 & 57,8 \\
\hline \multirow{4}{*}{3} & 1 & 1,1 & 6 & 96,5 & 39,8 \\
\hline & 2 & 2 & 7 & 97,5 & 46,6 \\
\hline & 3 & 2,5 & 6 & 35,1 & 24,0 \\
\hline & 4 & 1,5 & 12 & 574,9 & 193,0 \\
\hline \multirow{4}{*}{4} & 1 & 3 & 7 & 108,9 & 49,2 \\
\hline & 2 & 1,1 & 4 & 36,0 & 16,2 \\
\hline & 3 & 2 & 5 & 20,4 & 15,3 \\
\hline & 4 & 3 & 10 & 175,8 & 89,2 \\
\hline \multirow{4}{*}{5} & 1 & 1 & 6,6 & 58,0 & 33,9 \\
\hline & 2 & 1 & 4,5 & 87,3 & 28,4 \\
\hline & 3 & 2 & 4,5 & 25,8 & 15,5 \\
\hline & 4 & 5 & 7 & 161,1 & 59,8 \\
\hline \multirow{4}{*}{6} & 1 & 3,5 & 4,5 & 23,0 & 14,6 \\
\hline & 2 & 2 & 10 & 198,9 & 94,8 \\
\hline & 3 & 1,5 & 5 & 42,1 & 21,9 \\
\hline & 4 & 3 & 10 & 548,2 & 157,2 \\
\hline \multirow{4}{*}{7} & 1 & 3 & 7 & 748,8 & 128,7 \\
\hline & 2 & 1,5 & 6,5 & 71,6 & 37,1 \\
\hline & 3 & 2,5 & 9 & 325,9 & 109,2 \\
\hline & 4 & 3,5 & 6 & 232,5 & 61,6 \\
\hline \multirow{4}{*}{8} & 1 & 6 & 4 & 88,3 & 25,4 \\
\hline & 2 & 2 & 4 & 20,4 & 12,2 \\
\hline & 3 & 2 & 4 & 67,9 & 22,3 \\
\hline & 4 & 1 & 4 & 147,1 & 32,7 \\
\hline \multirow{4}{*}{9} & 1 & 2,2 & 6,6 & 140,4 & 52,7 \\
\hline & 2 & 1 & 3,5 & 31,8 & 13,4 \\
\hline & 3 & 2 & 8 & 242,2 & 83,8 \\
\hline & 4 & 1,5 & 7 & 45,8 & 32,0 \\
\hline \multirow{4}{*}{10} & 1 & 1,5 & 7 & 207,0 & 67,8 \\
\hline & 2 & 4 & 7 & 45,8 & 32,0 \\
\hline & 3 & 3 & 8 & 154,1 & 66,9 \\
\hline & 4 & 2,5 & 15 & 1243,4 & 354,1 \\
\hline
\end{tabular}




\begin{tabular}{|c|c|c|c|c|c|}
\hline Quadr & Indivíduo & Dist. (m) & Alt. (m) & $\mathrm{AB}\left(\mathrm{cm}^{2}\right)$ & Biomassa $(\mathrm{kg})$ \\
\hline \multirow{4}{*}{11} & 1 & 0,9 & 7 & 20,4 & 21,4 \\
\hline & 2 & 1,3 & 4 & 49,7 & 19,1 \\
\hline & 3 & 1 & 6 & 28,7 & 21,7 \\
\hline & 4 & 1 & 3 & 20,4 & 9,2 \\
\hline \multirow{4}{*}{12} & 1 & 2 & 8 & 447,6 & 113,7 \\
\hline & 2 & 2 & 5 & 23,0 & 16,2 \\
\hline & 3 & 1 & 5 & 31,8 & 19,1 \\
\hline & 4 & 1,5 & 3,5 & 17,9 & 10,0 \\
\hline \multirow{4}{*}{13} & 1 & 2 & 4 & 49,7 & 19,1 \\
\hline & 2 & 1 & 9 & 66,9 & 49,6 \\
\hline & 3 & 1,5 & 7 & 42,1 & 30,7 \\
\hline & 4 & 1,5 & 4 & 17,9 & 11,5 \\
\hline \multirow{4}{*}{14} & 1 & 2,5 & 6 & 58,0 & 30,8 \\
\hline & 2 & 7 & 4,5 & 45,8 & 20,6 \\
\hline & 3 & 5 & 4 & 114,9 & 28,9 \\
\hline & 4 & 0,5 & 5 & 42,1 & 21,9 \\
\hline \multirow{4}{*}{15} & 1 & 1 & 5 & 23,0 & 16,2 \\
\hline & 2 & 1,5 & 7 & 81,5 & 42,6 \\
\hline & 3 & 2 & 4 & 116,7 & 29,2 \\
\hline & 4 & 4 & 7 & 17,9 & 20,0 \\
\hline \multirow{4}{*}{16} & 1 & 2 & 7 & 175,8 & 62,5 \\
\hline & 2 & 0,2 & 5 & 55,5 & 25,2 \\
\hline & 3 & 1 & 10 & 140,4 & 79,7 \\
\hline & 4 & 1,3 & 12 & 447,6 & 170,4 \\
\hline \multirow{4}{*}{17} & 1 & 3 & 12 & 154,1 & 100,1 \\
\hline & 2 & 4 & 12 & 121,0 & 88,8 \\
\hline & 3 & 0,5 & 7 & 49,7 & 33,3 \\
\hline & 4 & 4 & 10 & 175,8 & 89,2 \\
\hline \multirow{4}{*}{18} & 1 & 1,5 & 10 & 305,9 & 117,5 \\
\hline & 2 & 4 & 7 & 23,0 & 22,7 \\
\hline & 3 & 3 & 6 & 105,4 & 41,5 \\
\hline & 4 & 3 & 5 & 81,5 & 30,5 \\
\hline \multirow{4}{*}{19} & 1 & 3 & 3 & 38,5 & 12,6 \\
\hline & 2 & 3 & 13 & 223,5 & 130,6 \\
\hline & 3 & 2,5 & 5 & 56,4 & 25,4 \\
\hline & 4 & 4 & 10 & 161,1 & 85,4 \\
\hline \multirow{4}{*}{20} & 1 & 2 & 5 & 38,5 & 21,0 \\
\hline & 2 & 3 & 5 & 28,7 & 18,1 \\
\hline & 3 & 1,5 & 6 & 31,8 & 22,9 \\
\hline & 4 & 3 & 5 & 20,4 & 15,3 \\
\hline
\end{tabular}


Área 9B

Biomassa: 111,9 T/ha.

Área basal média: $86,9 \mathrm{~m}^{2} /$ ha .

1016,6 árvores/ha.

\begin{tabular}{|c|c|c|c|c|c|}
\hline Quadr & Indivíduo & Dist. (m) & Alt. $(\mathrm{m})$ & $A B\left(\mathrm{~cm}^{2}\right)$ & Biomassa(kg) \\
\hline \multirow{4}{*}{1} & 1 & 2,8 & 6 & 92,0 & 21,0 \\
\hline & 2 & 3,7 & 8 & 127,3 & 38,8 \\
\hline & 3 & 3,3 & 10 & 103,1 & 39,2 \\
\hline & 4 & 5,6 & 12 & 175,8 & 80,1 \\
\hline \multirow{4}{*}{2} & 1 & 1,3 & 9 & 175,8 & 60,1 \\
\hline & 2 & 6,3 & 12 & 357,2 & 162,3 \\
\hline & 3 & 6,0 & 12 & 522,1 & 237,0 \\
\hline & 4 & 6,5 & 12 & 1222,1 & 553,1 \\
\hline \multirow{4}{*}{3} & 1 & 2,6 & 5 & 97,5 & 18,6 \\
\hline & 2 & 2,8 & 8 & 114,9 & 35,0 \\
\hline & 3 & 1,0 & 7 & 140,4 & 37,4 \\
\hline & 4 & 3,0 & 9 & 315,8 & 107,8 \\
\hline \multirow{4}{*}{4} & 1 & 0,5 & 10 & 648,2 & 245,1 \\
\hline & 2 & 4,4 & 8 & 124,0 & 37,7 \\
\hline & 3 & 6,7 & 9 & 175,8 & 60,1 \\
\hline & 4 & 3,8 & 9 & 325,9 & 111,2 \\
\hline \multirow{4}{*}{5} & 1 & 2,6 & 10 & 97,5 & 37,1 \\
\hline & 2 & 1,7 & 9 & 258,5 & 88,3 \\
\hline & 3 & 4,0 & 4 & 103,1 & 15,7 \\
\hline & 4 & 2,7 & 14 & 286,5 & 151,9 \\
\hline \multirow{4}{*}{6} & 1 & 1,3 & 7 & 147,1 & 39,2 \\
\hline & 2 & 2,0 & 10 & 346,6 & 131,4 \\
\hline & 3 & 1,3 & 9 & 108,9 & 37,3 \\
\hline & 4 & 3,4 & 6 & 97,5 & 22,3 \\
\hline \multirow{4}{*}{7} & 1 & 1,7 & 9 & 401,2 & 136,8 \\
\hline & 2 & 1,4 & 7 & 92,0 & 24,5 \\
\hline & 3 & 2,0 & 7 & 140,4 & 37,4 \\
\hline & 4 & 2,1 & 6 & 86,7 & 19,8 \\
\hline \multirow{4}{*}{8} & 1 & 1,3 & 12 & 225,8 & 102,8 \\
\hline & 2 & 2,5 & 8 & 133,8 & 40,7 \\
\hline & 3 & 2,7 & 10 & 401,2 & 152,0 \\
\hline & 4 & 4,1 & 9 & 662,2 & 225,4 \\
\hline \multirow{4}{*}{9} & 1 & 2,5 & 12 & 449,5 & 204,1 \\
\hline & 2 & 0,8 & 11 & 207,0 & 86,4 \\
\hline & 3 & 2,6 & 8 & 325,9 & 98,9 \\
\hline & 4 & 3,3 & 7 & 223,5 & 59,5 \\
\hline \multirow{4}{*}{10} & 1 & 2,3 & 4,5 & 127,3 & 21,8 \\
\hline & 2 & 1,9 & 6 & 161,1 & 36,8 \\
\hline & 3 & 2,7 & 4,5 & 175,8 & 30,1 \\
\hline & 4 & 3,1 & 8 & 127,3 & 38,8 \\
\hline
\end{tabular}




\begin{tabular}{|c|c|c|c|c|c|}
\hline Quadr & Indivíduo & Dist. (m) & Alt. (m) & $\mathrm{AB}\left(\mathrm{cm}^{2}\right)$ & Biomassa(kg) \\
\hline \multirow{4}{*}{11} & 1 & 2,6 & 10 & 325,9 & 123,6 \\
\hline & 2 & 2,9 & 10 & 368,0 & 139,4 \\
\hline & 3 & 3,7 & 10 & 97,5 & 37,1 \\
\hline & 4 & 3,6 & 11 & 140,4 & 58,7 \\
\hline \multirow{4}{*}{12} & 1 & 5,2 & 8 & 460,2 & 139,5 \\
\hline & 2 & 1,3 & 8 & 140,4 & 42,7 \\
\hline & 3 & 4,0 & 9 & 258,5 & 88,3 \\
\hline & 4 & 4,8 & 7,5 & 97,5 & 27,9 \\
\hline \multirow{4}{*}{13} & 1 & 2,5 & 12 & 509,3 & 231,2 \\
\hline & 2 & 2,4 & 13 & 471,8 & 232,0 \\
\hline & 3 & 4,2 & 8 & 92,0 & 28,0 \\
\hline & 4 & 3,9 & 9 & 368,0 & 125,5 \\
\hline \multirow{4}{*}{14} & 1 & 2,7 & 7 & 71,6 & 19,1 \\
\hline & 2 & 1,1 & 12 & 212,9 & 96,9 \\
\hline & 3 & 1,9 & 8 & 114,9 & 35,0 \\
\hline & 4 & 1,4 & 9 & 147,1 & 50,3 \\
\hline \multirow{4}{*}{15} & 1 & 2,0 & 7 & 303,1 & 80,5 \\
\hline & 2 & 0,8 & 8 & 140,4 & 42,7 \\
\hline & 3 & 2,3 & 9 & 368,0 & 125,5 \\
\hline & 4 & 6,0 & 10 & 378,9 & 143,5 \\
\hline \multirow{4}{*}{16} & 1 & 1,8 & 12 & 191,1 & 87,0 \\
\hline & 2 & 1,9 & 10 & 131,9 & 50,2 \\
\hline & 3 & 3,5 & 7 & 81,5 & 21,7 \\
\hline & 4 & 4,3 & 8 & 121,0 & 36,9 \\
\hline \multirow{4}{*}{17} & 1 & 2,0 & 12 & 0,1 & 0,1 \\
\hline & 2 & 1,5 & 11 & 277,0 & 115,5 \\
\hline & 3 & 6,0 & 10 & 193,0 & 73,3 \\
\hline & 4 & 8,3 & 13 & 401,2 & 197,4 \\
\hline \multirow{4}{*}{18} & 1 & 1,9 & 8 & 86,7 & 26,4 \\
\hline & 2 & 3,6 & 15 & 962,9 & 544,8 \\
\hline & 3 & 3,0 & 15 & 1052,4 & 595,3 \\
\hline & 4 & 8,2 & 8 & 127,3 & 38,8 \\
\hline \multirow{4}{*}{19} & 1 & 4,1 & 14 & 400,4 & 212,1 \\
\hline & 2 & 1,6 & 12 & 411,0 & 186,7 \\
\hline & 3 & 6,8 & 14 & 412,5 & 218,5 \\
\hline & 4 & 3,2 & 8 & 305,9 & 92,8 \\
\hline \multirow{4}{*}{20} & 1 & 4,1 & 15 & 1191,2 & 673,5 \\
\hline & 2 & 3,5 & 7 & 86,7 & 23,1 \\
\hline & 3 & 3,2 & 8 & 97,5 & 29,7 \\
\hline & 4 & 3,3 & 8 & 103,1 & 31,4 \\
\hline
\end{tabular}


Área 10B

Biomassa: 124,4 T/ha.

Área basal média: $36,9 \mathrm{~m}^{2} / \mathrm{ha}$

980,4 árvores/ha.

\begin{tabular}{|c|c|c|c|c|c|}
\hline Quadr & Indivíduo & Dist. (m) & Alt. (m) & $\mathrm{AB}\left(\mathrm{cm}^{2}\right)$ & Biomassa $(\mathrm{kg})$ \\
\hline \multirow{4}{*}{1} & 1 & 3,25 & 7 & 223,5 & 59,5 \\
\hline & 2 & 1,7 & 10 & 1108,0 & 418,3 \\
\hline & 3 & 2,7 & 4 & 357,2 & 54,3 \\
\hline & 4 & 4 & 7 & 447,6 & 118,8 \\
\hline \multirow{4}{*}{2} & 1 & 6,4 & 7 & 305,9 & 81,3 \\
\hline & 2 & 0,8 & 9 & 1108,0 & 376,6 \\
\hline & 3 & 5,2 & 6 & 81,5 & 18,6 \\
\hline & 4 & 5,8 & 7 & 353,0 & 93,8 \\
\hline \multirow{4}{*}{3} & 1 & 2 & 7 & 258,5 & 68,7 \\
\hline & 2 & 4,5 & 8 & 447,6 & 135,7 \\
\hline & 3 & 3,3 & 5,5 & 76,5 & 16,1 \\
\hline & 4 & 4,5 & 6 & 71,6 & 16,4 \\
\hline \multirow{4}{*}{4} & 1 & 2,7 & 8 & 286,5 & 87,0 \\
\hline & 2 & 4,95 & 10 & 121,0 & 46,0 \\
\hline & 3 & 4,25 & 5 & 127,3 & 24,3 \\
\hline & 4 & 1,7 & 8 & 697,5 & 211,1 \\
\hline \multirow{4}{*}{5} & 1 & 1,6 & 7 & 357,8 & 95,0 \\
\hline & 2 & 3,7 & 8 & 368,0 & 111,6 \\
\hline & 3 & 1,6 & 7 & 110,1 & 29,4 \\
\hline & 4 & 5,5 & 7 & 71,6 & 19,1 \\
\hline \multirow{4}{*}{6} & 1 & 3,5 & 7 & 97,5 & 26,0 \\
\hline & 2 & 4,3 & 8 & 305,9 & 92,8 \\
\hline & 3 & 3 & 8 & 368,0 & 111,6 \\
\hline & 4 & 1,9 & 6 & 103,1 & 23,6 \\
\hline \multirow{4}{*}{7} & 1 & 1,28 & 7 & 140,4 & 37,4 \\
\hline & 2 & 3,6 & 8 & 484,1 & 146,7 \\
\hline & 3 & 1,9 & 7 & 114,9 & 30,6 \\
\hline & 4 & 5,8 & 12 & 688,3 & 312,1 \\
\hline \multirow{4}{*}{8} & 1 & 2,18 & 8 & 315,8 & 95,9 \\
\hline & 2 & 1,9 & 7 & 378,9 & 100,6 \\
\hline & 3 & 2,5 & 8 & 874,1 & 264,4 \\
\hline & 4 & 2,8 & 7 & 114,9 & 30,6 \\
\hline \multirow{4}{*}{9} & 1 & 3,4 & 8 & 424,1 & 128,6 \\
\hline & 2 & 1,5 & 12 & 296,1 & 134,7 \\
\hline & 3 & 2,2 & 9 & 296,1 & 101,1 \\
\hline & 4 & 3,2 & 6 & 195,6 & 44,6 \\
\hline \multirow{4}{*}{10} & 1 & 2,7 & 8 & 447,6 & 135,7 \\
\hline & 2 & 1,9 & 5 & 147,1 & 28,0 \\
\hline & 3 & 2,48 & 12 & 401,2 & 182,2 \\
\hline & 4 & 2,8 & 10 & 336,2 & 127,4 \\
\hline
\end{tabular}




\begin{tabular}{|c|c|c|c|c|c|}
\hline Quadr & Indivíduo & Dist. (m) & Alt. (m) & $\mathrm{AB}\left(\mathrm{cm}^{2}\right)$ & Biomassa $(\mathrm{kg})$ \\
\hline \multirow{4}{*}{11} & 1 & 0,8 & 7 & 412,9 & 109,6 \\
\hline & 2 & 2,5 & 7 & 140,4 & 37,4 \\
\hline & 3 & 6,8 & 7 & 140,4 & 37,4 \\
\hline & 4 & 6,6 & 12 & 1052,4 & 476,6 \\
\hline \multirow{4}{*}{12} & 1 & 1 & 12 & 315,8 & 143,6 \\
\hline & 2 & 2,7 & 13 & 1413,7 & 692,7 \\
\hline & 3 & 3,3 & 5 & 133,8 & 25,5 \\
\hline & 4 & 2,7 & 12 & 1274,9 & 577,0 \\
\hline \multirow{4}{*}{13} & 1 & 5,5 & 10 & 1376,7 & 519,4 \\
\hline & 2 & 5,7 & 12 & 508,4 & 230,8 \\
\hline & 3 & 2,5 & 8 & 703,1 & 212,8 \\
\hline & 4 & 4,6 & 10 & 764,3 & 288,9 \\
\hline \multirow{4}{*}{14} & 1 & 4,48 & 7 & 92,0 & 24,5 \\
\hline & 2 & 1 & 8 & 354,1 & 107,4 \\
\hline & 3 & 4,2 & 6 & 200,6 & 45,8 \\
\hline & 4 & 4,6 & 8 & 517,0 & 156,7 \\
\hline \multirow{4}{*}{15} & 1 & 4,8 & 7 & 127,3 & 33,9 \\
\hline & 2 & 1,1 & 7 & 325,9 & 86,6 \\
\hline & 3 & 2,5 & 7 & 315,8 & 83,9 \\
\hline & 4 & 6,3 & 9 & 687,7 & 234,1 \\
\hline \multirow{4}{*}{16} & 1 & 2,4 & 4 & 296,1 & 45,0 \\
\hline & 2 & 2,3 & 10 & 718,4 & 271,6 \\
\hline & 3 & 1,9 & 7 & 569,9 & 151,1 \\
\hline & 4 & 5,3 & 8 & 140,4 & 42,7 \\
\hline \multirow{4}{*}{17} & 1 & 3,4 & 10 & 305,9 & 116,0 \\
\hline & 2 & 1,8 & 7 & 183,3 & 48,8 \\
\hline & 3 & 1,9 & 10 & 267,7 & 101,5 \\
\hline & 4 & 3,7 & 8 & 305,9 & 92,8 \\
\hline \multirow{4}{*}{18} & 1 & 3,4 & 7 & 103,1 & 27,5 \\
\hline & 2 & 2,1 & 8 & 133,8 & 40,7 \\
\hline & 3 & 2,3 & 7 & 86,7 & 23,1 \\
\hline & 4 & 5,9 & 9 & 286,5 & 97,8 \\
\hline \multirow{4}{*}{19} & 1 & 1,9 & 8 & 565,4 & 171,3 \\
\hline & 2 & 1,1 & 10 & 127,3 & 48,4 \\
\hline & 3 & 1,62 & 10 & 258,5 & 98,1 \\
\hline & 4 & 3,15 & 7 & 240,7 & 64,0 \\
\hline \multirow{4}{*}{20} & 1 & 1,65 & 8 & 535,1 & 162,1 \\
\hline & 2 & 1,51 & 5 & 103,1 & 19,7 \\
\hline & 3 & 4,7 & 8 & 430,6 & 130,6 \\
\hline & 4 & 4,8 & 7 & 127,3 & 33,9 \\
\hline
\end{tabular}




\section{Anexo 2}

Lista das espécies vegetais do componente lenhoso, encontradas na área de estudo. Levantamentos realizados por Durigan (2000) em setembro e outubro de 1999. Método utilizado: levantamento botânico expedito (RATTER et al. 2000a,b e

RATTER et al. 2003).

\begin{tabular}{|c|c|}
\hline Família & Espécie \\
\hline Anacardiaceae & Anacardium humile \\
\hline Anacardiaceae & Lithraea molleoides \\
\hline Anacardiaceae & Tapirira guianensis \\
\hline Annonaceae & Annona cacans \\
\hline Annonaceae & Annona coriacea \\
\hline Annonaceae & Annona crassiflora \\
\hline Annonaceae & Annona dioica \\
\hline Annonaceae & Duguetia lanceolata \\
\hline Annonaceae & Xylopia aromatica \\
\hline Apocynaceae & Aspidosperma tomentosum \\
\hline Apocynaceae & Himatanthus obovatus \\
\hline Apocynaceae & Mandevilla velutina \\
\hline Apocynaceae & Tabernaemontana hystrix \\
\hline Aquifoliaceae & Ilex affinis \\
\hline Aquifoliaceae & Ilex brasiliensis \\
\hline Araliaceae & Schefflera vinosum \\
\hline Arecaceae & Syagrus romanzoffiana \\
\hline Asteraceae & Baccharis dracunculifolia \\
\hline Asteraceae & Gochnatia polymorpha \\
\hline Asteraceae & Piptocarpha axillaris \\
\hline Asteraceae & Piptocarpha rotundifolia \\
\hline Bignoniaceae & Anemopaegma arvense \\
\hline Bignoniaceae & Arrabidaea brachypoda \\
\hline Bignoniaceae & Jacaranda caroba \\
\hline Bignoniaceae & Jacaranda decurrens \\
\hline Bignoniaceae & Memora axillaris \\
\hline Bignoniaceae & Tabebuia heptaphylla \\
\hline Bignoniaceae & Tabebuia ochracea \\
\hline Bixaceae & Cochlospermum regium \\
\hline Bombacaceae & Eriotheca gracilipes \\
\hline Boraginaceae & Cordia sellowiana \\
\hline Bromeliaceae & Bromelia balansae \\
\hline Burseraceae & Protium heptaphyllum \\
\hline
\end{tabular}




\begin{tabular}{|c|c|}
\hline Família & Espécie \\
\hline Caesalpiniaceae & Bauhinia longifolia \\
\hline Caesalpiniaceae & Bauhinia rufa \\
\hline Caesalpiniaceae & Bauhinia ungulata \\
\hline Caesalpiniaceae & Copaifera langsdorffii \\
\hline Caesalpiniaceae & Dimorphandra mollis \\
\hline Caesalpiniaceae & Peltophorum dubium \\
\hline Caesalpiniaceae & Senna pendula \\
\hline Caesalpiniaceae & Senna rugosa \\
\hline Caryocaraceae & Caryocar brasiliense \\
\hline Cecropiaceae & Cecropia pachystachya \\
\hline Celastraceae & Austroplenckia populnea \\
\hline Celastraceae & Maytenus aquifolium \\
\hline Celastraceae & Maytenus robusta \\
\hline Chrysobalanaceae & Couepia grandiflora \\
\hline Chrysobalanaceae & Licania humilis \\
\hline Combretaceae & Terminalia glabrescens \\
\hline Connaraceae & Connarus suberosus \\
\hline Cunoniaceae & Lamanonia ternata \\
\hline Dilleniaceae & Davilla elliptica \\
\hline Ebenaceae & Diospyros hispida \\
\hline Erythroxylaceae & Erythroxylum cuneifolium \\
\hline Erythroxylaceae & Erythroxylum deciduum \\
\hline Erythroxylaceae & Erythroxylum pelleterianum \\
\hline Erythroxylaceae & Erythroxylum suberosum \\
\hline Euphorbiaceae & Actinostemon conceptionis \\
\hline Euphorbiaceae & Croton floribundus \\
\hline Euphorbiaceae & Mabea fistulifera \\
\hline Euphorbiaceae & Manihot tripartita \\
\hline Euphorbiaceae & Maprounea guianensis \\
\hline Euphorbiaceae & Pera obovata \\
\hline Euphorbiaceae & Sebastiania brasiliensis \\
\hline Euphorbiaceae & Sebastiania commersoniana \\
\hline Fabaceae & Acosmium subelegans \\
\hline Fabaceae & Andira humilis \\
\hline Fabaceae & Bowdichia virgilioides \\
\hline Fabaceae & Dalbergia miscolobium \\
\hline Fabaceae & Machaerium aculeatum \\
\hline Fabaceae & Machaerium acutifolium \\
\hline
\end{tabular}




\begin{tabular}{|c|c|}
\hline Família & Espécie \\
\hline Fabaceae & Machaerium brasiliense \\
\hline Fabaceae & Machaerium stipitatum \\
\hline Fabaceae & Ormosia arborea \\
\hline Fabaceae & Platypodium elegans \\
\hline Flacourtiaceae & Casearia sylvestris \\
\hline Flacourtiaceae & Xylosma venosum \\
\hline Hippocrateaceae & Peritassa campestris \\
\hline Hippocrateaceae & Tontelea micrantha \\
\hline Icacinaceae & Citronella gongonha \\
\hline Lacistemataceae & Lacistema hasslerianum \\
\hline Lauraceae & Aiouea trinervis \\
\hline Lauraceae & Nectandra cuspidata \\
\hline Lauraceae & Ocotea corymbosa \\
\hline Lauraceae & Ocotea minarum \\
\hline Lauraceae & Ocotea velloziana \\
\hline Lauraceae & Ocotea velutina \\
\hline Lauraceae & Persea pyrifolia \\
\hline Lauraceae & Persea pyrifolia \\
\hline Lythraceae & Lafoensia pacari \\
\hline Malpighiaceae & Byrsonima intermedia \\
\hline Malpighiaceae & Byrsonima pachyphylla \\
\hline Melastomataceae & Miconia albicans \\
\hline Melastomataceae & Miconia chamissois \\
\hline Melastomataceae & Miconia falax \\
\hline Melastomataceae & Miconia hymenonervia \\
\hline Melastomataceae & Miconia langsdorffii \\
\hline Melastomataceae & Miconia ligustroides \\
\hline Melastomataceae & Miconia rubiginosa \\
\hline Melastomataceae & Miconia stenostachya \\
\hline Melastomataceae & Tibouchina stenocarpa \\
\hline Meliaceae & Cedrela fissilis \\
\hline Mimosaceae & Acacia polyphylla \\
\hline Mimosaceae & Albizia niopoides \\
\hline Mimosaceae & Anadenanthera falcata \\
\hline Mimosaceae & Calliandra foliolosa \\
\hline Mimosaceae & Enterolobium gummiferum \\
\hline Mimosaceae & Inga marginata \\
\hline Mimosaceae & Inga striata \\
\hline
\end{tabular}




\begin{tabular}{|c|c|}
\hline Família & Espécie \\
\hline Mimosaceae & Inga vera \\
\hline Mimosaceae & Plathymenia reticulata \\
\hline Mimosaceae & Stryphnodendron obovatum \\
\hline Monimiaceae & Siparuna guianensis \\
\hline Moraceae & Brosimum gaudichaudii \\
\hline Moraceae & Ficus eximia \\
\hline Moraceae & Sorocea bonplandii \\
\hline Myrsinaceae & Rapanea ferruginea \\
\hline Myrsinaceae & Rapanea gardneriana \\
\hline Myrsinaceae & Rapanea umbellata \\
\hline Myrtaceae & Calyptranthes concinna \\
\hline Myrtaceae & Campomanesia adamantium \\
\hline Myrtaceae & Campomanesia guazumaefolia \\
\hline Myrtaceae & Eugenia aurata \\
\hline Myrtaceae & Eugenia birmaginata \\
\hline Myrtaceae & Eugenia blastantha \\
\hline Myrtaceae & Eugenia pluriflora \\
\hline Myrtaceae & Eugenia punicifolia \\
\hline Myrtaceae & Eugenia pyriformis \\
\hline Myrtaceae & Eugenia speciosa \\
\hline Myrtaceae & Hexachlamys edulis \\
\hline Myrtaceae & Myrcia bella \\
\hline Myrtaceae & Myrcia guianensis \\
\hline Myrtaceae & Myrcia lingua \\
\hline Myrtaceae & Myrcia multiflora \\
\hline Myrtaceae & Myrcia tomentosa \\
\hline Myrtaceae & Myrcia venulosa \\
\hline Myrtaceae & Myrciaria ciliolata \\
\hline Myrtaceae & Myrciaria delicatula \\
\hline Myrtaceae & Psidium australe \\
\hline Myrtaceae & Psidium cinereum \\
\hline Myrtaceae & Psidium guineense \\
\hline Myrtaceae & Psidium rufum \\
\hline Nyctaginaceae & Guapira noxia \\
\hline Ochnaceae & Ouratea spectabilis \\
\hline Opiliaceae & Agonandra brasiliensis \\
\hline Polygonaceae & Coccoloba mollis \\
\hline Proteaceae & Roupala adiantifolia \\
\hline
\end{tabular}




\begin{tabular}{|c|c|}
\hline Família & Espécie \\
\hline Proteaceae & Roupala montana \\
\hline Rosaceae & Prunus myrtifolia \\
\hline Rubiaceae & Alibertia concolor \\
\hline Rubiaceae & Alibertia sessilis \\
\hline Rubiaceae & Amaioua guianensis \\
\hline Rubiaceae & Coutarea hexandra \\
\hline Rubiaceae & Ixora venulosa \\
\hline Rubiaceae & Palicourea rigida \\
\hline Rubiaceae & Randia armata \\
\hline Rubiaceae & Tocoyena formosa \\
\hline Rutaceae & Esenbeckia febrifuga \\
\hline Rutaceae & Helietta apiculata \\
\hline Rutaceae & Zanthoxylum hyemale \\
\hline Rutaceae & Zanthoxylum rhoifolium \\
\hline Sapindaceae & Allophyllus edulis \\
\hline Sapindaceae & Cupania tenuivalvis \\
\hline Sapindaceae & Cupania vernalis \\
\hline Sapindaceae & Matayba elaeagnoides \\
\hline Sapindaceae & Talisia pygmaea \\
\hline Sapotaceae & Chrysophyllum marginatum \\
\hline Sapotaceae & Pouteria ramiflora \\
\hline Sapotaceae & Pouteria torta \\
\hline Solanaceae & Solanum lycocarpum \\
\hline Solanaceae & Solanum paniculatum \\
\hline Sterculiaceae & Guazuma ulmifolia \\
\hline Styracaceae & Styrax camporum \\
\hline Styracaceae & Styrax ferrugineus \\
\hline Symplocaceae & Symplocos pubescens \\
\hline Thymelaceae & Daphnopsis racemosa \\
\hline Tiliaceae & Luehea candicans \\
\hline Tiliaceae & Luehea grandiflora \\
\hline Ulmaceae & Trema micrantha \\
\hline Verbenaceae & Aegiphila sellowiana \\
\hline Verbenaceae & Vitex montevidensis \\
\hline Vochysiaceae & Qualea cordata \\
\hline Vochysiaceae & Qualea grandiflora \\
\hline Vochysiaceae & Qualea multiflora \\
\hline Vochysiaceae & Vochysia tucanorum \\
\hline
\end{tabular}


